\title{
Late Holocene Volcanism at Medicine Lake Volcano, Northern California Cascades
}

Professional Paper 1822
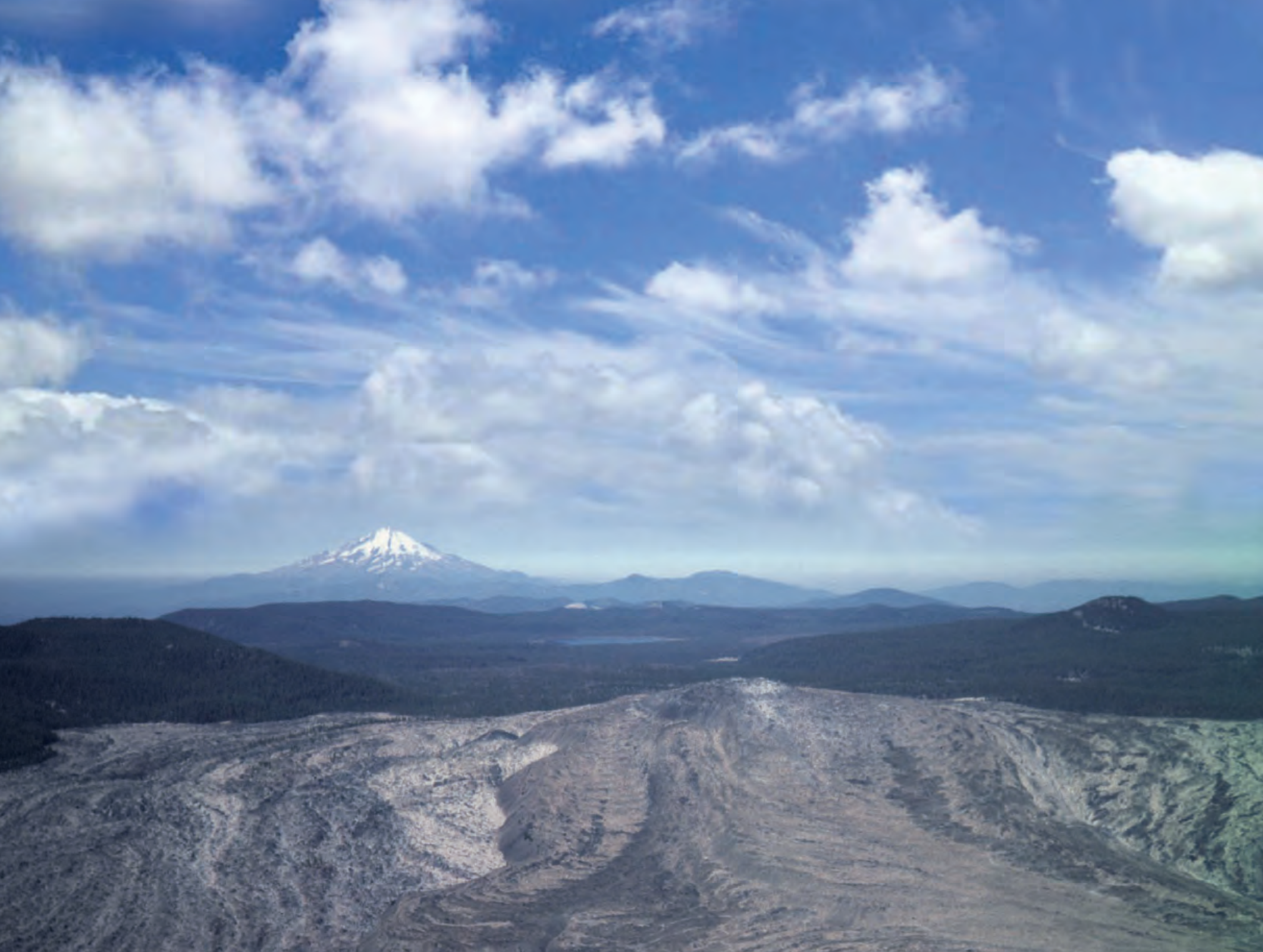
COVER PHOTO

Aerial view looking west across the $\sim 950$-yr-old Glass Mountain lava flow. Snow-covered Mount Shasta is on the horizon. Medicine Lake can be seen beyond and to the left of dome of Glass Mountain proper. The lake lies within the Medicine Lake caldera at the center of Medicine Lake volcano. 


\section{Late Holocene Volcanism at Medicine Lake Volcano, Northern California Cascades}

By Julie M. Donnelly-Nolan, Duane E. Champion, and Timothy L. Grove

Professional Paper 1822 


\title{
U.S. Department of the Interior SALLY JEWELL, Secretary
}

\section{U.S. Geological Survey Suzette M. Kimball, Director}

\author{
U.S. Geological Survey, Reston, Virginia: 2016
}

For more information on the USGS - the Federal source for science about the Earth, its natural and living resources, natural hazards, and the environment - visit http://www.usgs.gov or call 1-888-ASK-USGS

For an overview of USGS information products, including maps, imagery, and publications, visit http://store.usgs.gov

Any use of trade, firm, or product names is for descriptive purposes only and does not imply endorsement by the U.S. Government.

Although this information product, for the most part, is in the public domain, it also may contain copyrighted materials as noted in the text. Permission to reproduce copyrighted items must be secured from the copyright owner.

Suggested citation:

Donnelly-Nolan, J.M., Champion, D.E., and Grove, T.L., 2016, Late Holocene volcanism at Medicine Lake volcano, northern California Cascades: U.S. Geological Survey Professional Paper 1822, 59 p.,

http://dx.doi.org/10.3133/pp1822.

ISSN 2330-7102 (online) ISSN 1044-9612 (print) ISBN 978-1-4113-4037-4 


\section{Contents}

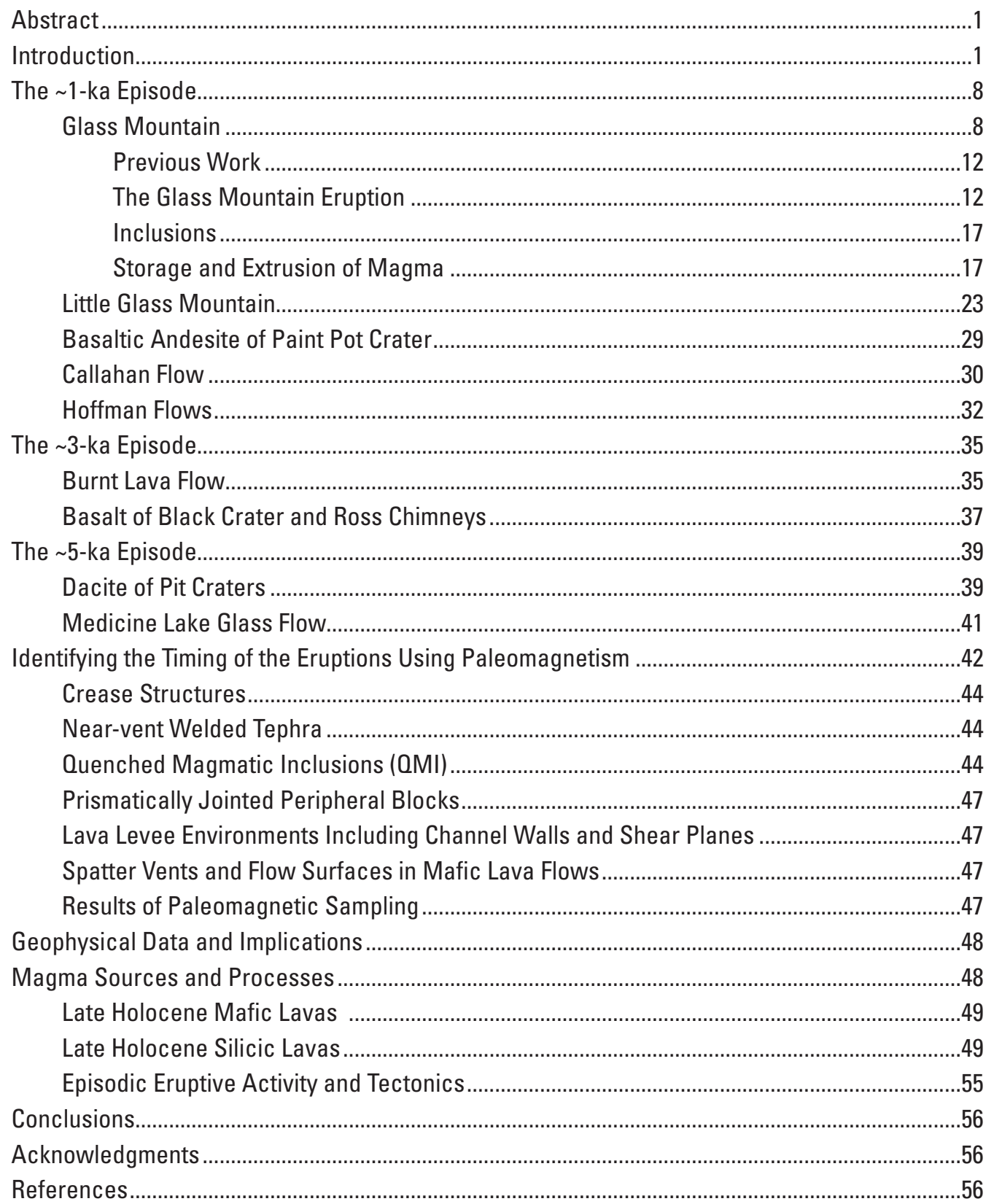




\section{Figures}

1. Shaded relief location maps showing major volcanoes of the Cascades volcanic arc, and a part of northern California showing Mount Shasta, the Cascades axis, and Medicine Lake volcano.

2. Photographs showing view south across basaltic lava in Lava Beds National Monument toward the main edifice of Medicine Lake volcano, and aerial view of Medicine Lake in the central caldera of the volcano.

3. Shaded relief map of Medicine Lake volcano adapted from Donnelly-Nolan and others.........4

4. Maps featuring Holocene lavas at Medicine Lake volcano ..................................................5

5. Plots showing chemical composition of late Holocene lavas and magmatic inclusions compared to the range of all other lavas erupted from Medicine Lake volcano

6. Photograph taken from rim of late Holocene Paint Pot Crater showing the black and red coloring of this youngest mafic cinder cone at Medicine Lake volcano mantled by white pumice from the adjacent and slightly younger Little Glass Mountain eruption

7. Aerial view looking northwest across the upper part of the Glass Mountain flow ...................9

8. Aerial view looking west-southwest across the central part of Medicine Lake volcano toward Mount Shasta dimly seen through haze on the horizon.

9. View westward toward the dome of Glass Mountain from eastern zone of mingled and spine-covered rhyodacitic lava

10. Views east across the northern Glass Mountain vent fissure.

11. Photo of Glass Mountain tephra taken in 1987 during active quarrying adjacent to and east of dome 10

12. Photo shows elongate pinkish band of pumice breccia, easily identified by the trees that grow in this zone of broken, brecciated, and in part oxidized pumice and lava.

13. Map showing compositional variation within the Glass Mountain flow and domes..............14

14. Photomicrographs of Glass Mountain lavas in order of decreasing silica content ...............15

15. View looking east along old bulldozer road that extends across the eastern part of the main Glass Mountain flow

16. Photograph of a single block of Glass Mountain mingled lava, shows quenched magmatic inclusions, porphyritic dacite, and a band of aphyric rhyolitic obsidian..........................16

17. Map showing the distribution of the variety of inclusions found in Glass Mountain lavas...18

18. Photomicrographs of quenched magmatic inclusions in Glass Mountain lavas ...................19

19. Photomicrographs of cumulate-textured inclusions in Glass Mountain lavas........................20

20. Photomicrographs of plutonic inclusions in late Holocene silicic lavas ................................21

21. Plots showing the full range of compositions found in Glass Mountain.................................22

22. Plots show the highest-silica compositions of the Glass Mountain eruption..........................23

23. Aerial view of Little Glass Mountain, looking west, with snow-covered Mount Shasta on

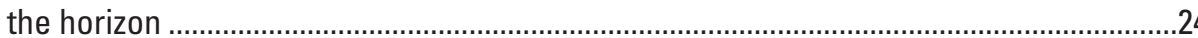

24. Aerial view looking northeast across the rocky and unvegetated Crater Glass flows ..........25

25. Aerial view looking southwest over the Crater Glass flows toward Little Glass Mountain along the entire length of the $\sim 1,000$-yr-old rhyolite eruptive fissure...

26. The Little Glass Mountain eruption was accompanied by the opening of cracks along, and

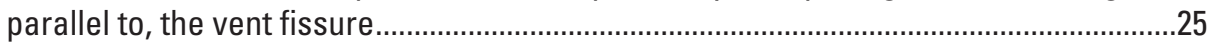

27. Map showing lavas erupted from the Little Glass Mountain fissure and vents ......................26

28. Photomicrographs of the Little Glass Mountain host lava and a variety of inclusions ..........27

29. Photograph showing typical occurrence of granitic inclusions found in Little Glass Mountain lava 
30. Largest sampled magmatic cumulate inclusion in Little Glass Mountain sits among blocks of rhyolite at the edge of the flow.

31. Plots comparing mafic magmatic inclusion suites in the Glass Mountain and Little Glass Mountain lavas.

32. Aerial view looking northeast across the late Holocene Paint Pot Crater flow and cone ....30

33. Photomicrographs of the late Holocene mafic host lavas ....................................................31

34. View northeast across the southern Callahan Flow and its main vent, Cinder Butte ............32

35. Aerial view west across the northern domes of the Glass Mountain fissure in the foreground to the northern part of the Hoffman flows in the center of view..........................33

36. Photomicrographs of the host lava and inclusions from the Hoffman flows ..........................34

37. Photograph of High Hole Crater, vent for the $\sim 3-k a$ Burnt Lava Flow, as seen across a part

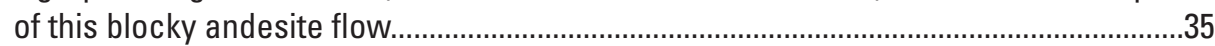

38. Plots showing compositional variability in the Burnt Lava Flow ..............................................35

39. Photomicrographs of quenched basaltic inclusions in the Burnt Lava Flow..........................36

40. Photograph of the uppermost Ross Chimneys spatter vents in northern Lava Beds National

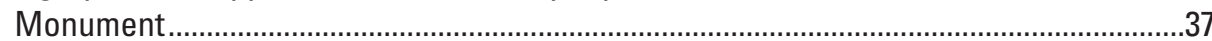

41. Outline map of the $~ 3-$ ka basalt of Black Crater and Ross Chimneys .....................................38

42. Paleomagnetic drilling in a crease structure on the surface of the Medicine Lake Glass Flow

43. Photomicrographs of the $\sim 5-k a$ dacitic lavas and inclusions

44. View west-southwest from Mount Hoffman, the highest point on the rim of Medicine Lake caldera, toward Mount Shasta...

45. Photograph showing the use of a sun compass to orient core samples collected for paleo-

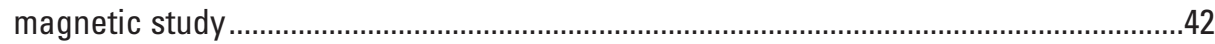

46. Map showing paleomagnetic site locations listed in table 3.................................................43

47. Paleomagnetic drilling in crease structures on the southern of the two Hoffman flows ......44

48. Photograph of welded near-vent agglutinate located adjacent to Glass Mountain dome 3

49. Photograph of drilling in a crease structure on dome 6, the smallest of the Glass Mountain

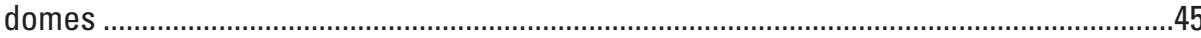

50. Photographs of paleomagnetic sampling at big crack in the center of the main Glass Mountain flow

51. Paleomagnetic drilling at Ross Chimneys in mafic lava showing evidence of fluid morphology.

52. Plots of paleomagnetic directions for late Holocene units grouped by age . .48

53. Silica variation diagrams showing compositions of mafic lavas and quenched magmatic inclusions erupted in late Holocene time....

54. Plot showing experimentally-determined compositional paths compared to the actual Glass Mountain compositions

55. Illustration showing Holocene eruptive episodes color-coded by composition as in figure $4 A$ for late Holocene time

56. Photographs showing examples of numerous open cracks at Medicine Lake volcano .......55 


\section{Tables}

[Tables 1-3 are supplemental and online only, table 4 included in text]

1. Chemical analyses of late Holocene lavas and magmatic inclusions.

2. Chemical analyses of plutonic inclusions in late Holocene lavas.

3. Late Holocene Medicine Lake volcano paleomagnetic data.

4. Summary of late Holocene erupted materials at Medicine Lake volcano

\section{Conversion Factors}

Inch/Pound to SI

\begin{tabular}{lcl}
\hline \multicolumn{1}{c}{ Multiply } & \multicolumn{1}{c}{ By } & \multicolumn{1}{c}{ To obtain } \\
\hline & \multicolumn{1}{c}{ Length } \\
\hline inch (in.) & 2.54 & centimeter (cm) \\
inch (in.) & 25.4 & millimeter (mm) \\
foot (ft) & 0.3048 & meter (m) \\
mile (mi) & 1.609 & kilometer (km) \\
yard (yd) & 0.9144 & meter (m) \\
\hline
\end{tabular}

\section{Abbreviations}

$\begin{array}{ll}\text { HAOT } & \begin{array}{l}\text { high-alumina olivine tholeiite } \\ \text { ka }\end{array} \\ \text { MLV } & \text { Medicine Lake volcano } \\ \text { PTRM } & \text { partial thermal remanent magnetization } \\ \text { OMI } & \text { quenched magmatic inclusions }\end{array}$




\title{
Late Holocene Volcanism at Medicine Lake Volcano, Northern California Cascades
}

\author{
by Julie M. Donnelly-Nolan', Duane E. Champion', and Timothy L. Grove ${ }^{2}$
}

\section{Abstract}

Late Holocene volcanism at Medicine Lake volcano in the southern Cascades arc exhibited widespread and compositionally diverse magmatism ranging from basalt to rhyolite. Nine well-characterized eruptions have taken place at this very large rear-arc volcano since 5,200 years ago, an eruptive frequency greater than nearly all other Cascade volcanoes. The lavas are widely distributed, scattered over an area of $\sim 300 \mathrm{~km}^{2}$ across the $>2,000-\mathrm{km}^{2}$ volcano. The eruptions are radiocarbon dated and the ages are also constrained by paleomagnetic data that provide strong evidence that the volcanic activity occurred in three distinct episodes at $\sim 1 \mathrm{ka}$, $\sim 3 \mathrm{ka}$, and $\sim 5 \mathrm{ka}$. The $\sim 1-\mathrm{ka}$ final episode produced a variety of compositions including west- and north-flank mafic flows interspersed in time with fissure rhyolites erupted tangential to the volcano's central caldera, including the youngest and most spectacular lava flow at the volcano, the $\sim 950$-yr-old compositionally zoned Glass Mountain flow. At $\sim 3 \mathrm{ka}$, a north-flank basalt eruption was followed by an andesite eruption $27 \mathrm{~km}$ farther south that contains quenched basalt inclusions. The $\sim 5$-ka episode produced two caldera-focused dacitic eruptions. Quenched magmatic inclusions record evidence of intrusions that did not independently reach the surface. The inclusions are present in five andesitic, dacitic, and rhyolitic host lavas, and were erupted in each of the three episodes. Compositional and mineralogic evidence from mafic lavas and inclusions indicate that both tholeiitic (dry) and calcalkaline (wet) parental magmas were present. Petrologic evidence records the operation of complex, multi-stage processes including fractional crystallization, crustal assimilation, and magma mixing. Experimental evidence suggests that magmas were stored at 3 to $6 \mathrm{~km}$ depth prior to eruption, and that both wet and dry parental magmas were involved in generating the more silicic magmas. The broad distribution of eruptive events and the relative accessibility and good exposure of lavas, combined with physical and petrologic evidence for multiple and varied mafic inputs, has created an unusual opportunity to understand the workings of this large magmatic system. A combined total of more than 25 intrusive and extrusive events are indicated for late Holocene time. Plutonic inclusions, some with ages as young as Holocene, were also brought to the surface in five of the eruptions. All eruptions took place along northwest- to

${ }^{1}$ U.S. Geological Survey

${ }^{2}$ Massachusetts Institute of Technology northeast-trending alignments of vents, reflecting the overall east-west extensional tectonic environment. The interaction of tectonism and volcanism is a dominant influence at this subduction-related volcano, located where the west edge of the extensional Basin and Range Province impinges on the Cascades arc. Ongoing subsidence focused at the central caldera has been documented along with geophysical evidence for a small magma body. This evidence, combined with the frequency of eruptive and intrusive activity in late Holocene time, an active geothermal system, and intermittent longperiod seismic events indicate that the volcano is likely to erupt again.

\section{Introduction}

Medicine Lake volcano (MLV) is a large shield-shaped volcano (figs. 1 and 2) that lies east of the southern Cascades arc axis $\sim 100 \mathrm{~km}$ above the surface of the subducting Juan de Fuca slab (McCrory and others, 2012). This subduction-related rear-arc Cascades volcano is located in an extensional tectonic setting where the Basin and Range Province impinges upon the arc. Some $600 \mathrm{~km}^{3}$ of lavas were erupted during its halfmillion-year history, ranging in composition from basalt (both tholeiitic and calcalkaline) to high-silica rhyolite (DonnellyNolan and others, 2008; Donnelly-Nolan, 2010) and covering more than 2,000 $\mathrm{km}^{2}$. Episodic volcanic activity has occurred throughout the volcano's history, none better documented than in postglacial time. Since ice melted off the volcano, 17 eruptions have taken place, 8 of them in a brief $\sim 200$-yr episode of basaltic eruptions $\sim 12,500$ years ago (Donnelly-Nolan and others, 2007). The 17 eruptions are unusually well understood in terms of their distribution in time, space, and composition (Donnelly-Nolan and others, 2007).

Late Holocene eruptive activity at MLV produced a remarkably diverse array of magmatic compositions (table 1, online only) ranging from basalt to rhyolite in nine well-dated eruptions representing one of the best-documented late Holocene records in the Cascades. The nine eruptions occurred in three episodes at $\sim 1 \mathrm{ka}, \sim 3 \mathrm{ka}$, and $\sim 5 \mathrm{ka}$ following an eruptive hiatus of $\sim 7,000$ years. Although not as widely distributed, nor as voluminous as the eight earlier eruptions, the late Holocene

${ }^{3}$ Details of the ages and their uncertainties are in Nathenson and others (2007), where the ages are listed in table 1 in calibrated years before present (B.P.), where present is, by convention, 1950. 

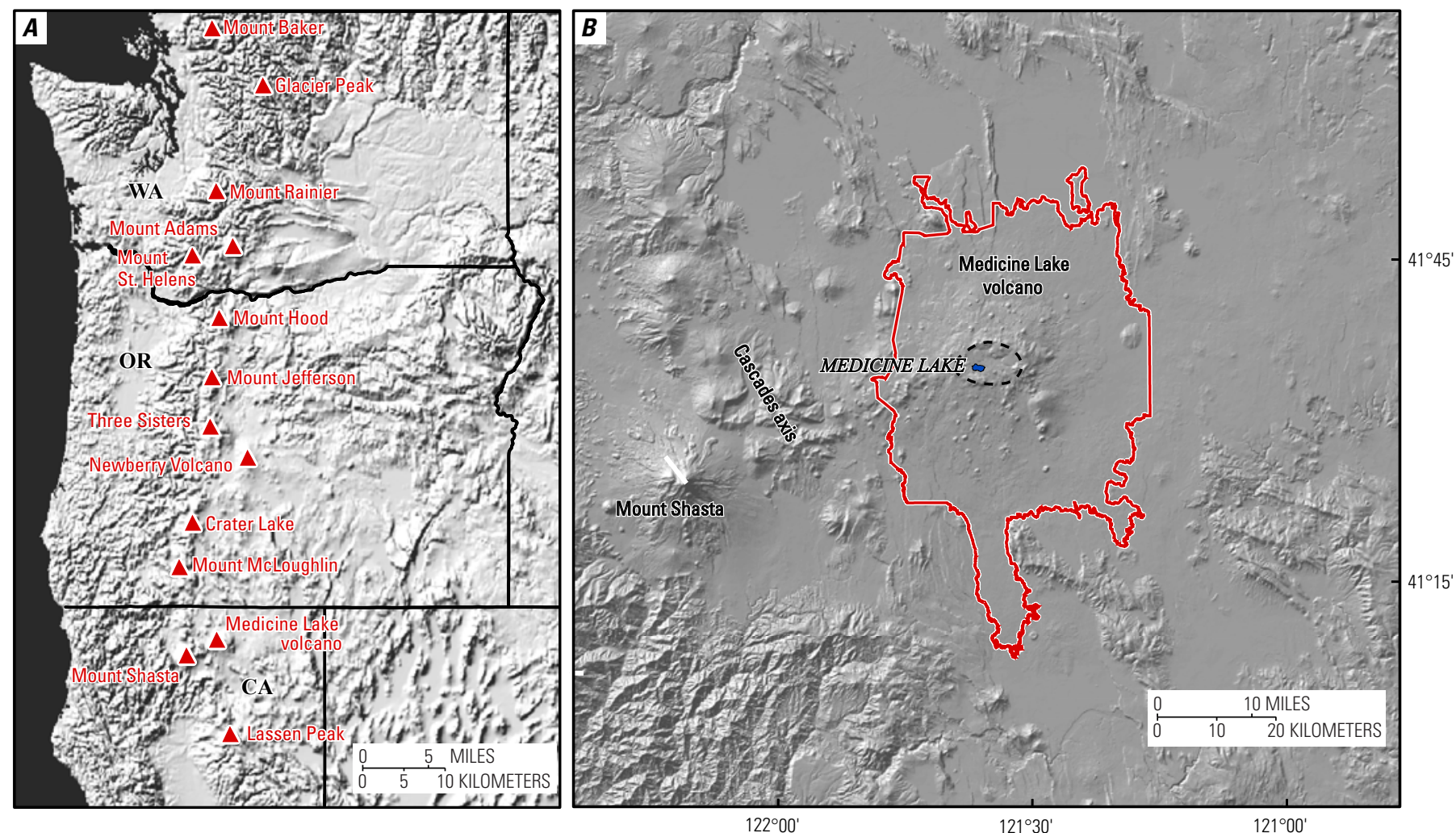

Figure 1. Shaded relief location maps showing $(A)$ major volcanoes of the Cascades volcanic arc, and $(B)$ a part of northern California showing Mount Shasta, the Cascades axis, and Medicine Lake volcano. Red outline of Medicine Lake lavas from Donnelly-Nolan (2010).

lavas nonetheless cover a total of $95 \mathrm{~km}^{2}$ scattered across a $300 \mathrm{~km}^{2}$ area that extends $33 \mathrm{~km}$ north-south by $19 \mathrm{~km}$ eastwest (fig. 3) centered on the volcano's summit caldera. For comparison, the area over which the lavas are scattered is twice the footprint of the Mt. St. Helens edifice.

Maps showing the distributions of the late Holocene lavas by episode and by composition are shown in figure $4 A, B$. Names of the eruptive units, along with areas, volumes, vent locations, and distribution are from Donnelly-Nolan (2010). Five of the nine late Holocene eruptions are silicic (rhyolite and dacite) and all of their vents are located within or immediately adjacent to the volcano's central caldera. The $\sim 1$-ka episode includes five eruptions between 950 and 1,230 years ago. In order of increasing age they are the rhyolite of Glass Mountain, the rhyolite of Little Glass Mountain, the basaltic andesite of Paint Pot Crater, the basaltic andesite of the Callahan Flow, and the rhyolite of the Hoffman flows. The $\sim 3$-ka episode includes the andesite of the Burnt Lava Flow and the basalt of Black Crater and Ross Chimneys. The $\sim 5$-ka episode includes two small silicic eruptions, the dacite of pit craters and the dacite of Medicine Lake Glass Flow.

Evidence for the ages of the postglacial eruptions and for identifying the episodes of activity came from both radiocarbon dating and from paleomagnetism (Nathenson and others, 2007). The role of paleomagnetism in constraining eruption ages was particularly important. Forty-three sites were drilled, of which 35 provided good directional information even for some very rugged, undissected young lava flows that presented significant sampling challenges. In this paper we discuss the variety of outcrop types that were drilled and describe the successes and failures, along with the laboratory approach to solving some paleomagnetic challenges. Of the 43 sites in late Holocene units that were sampled for paleomagnetism, 33 of the sites were in the $\sim 1$-ka units. Most of the effort was focused on the Glass Mountain (14 sites) and Little Glass Mountain (10 sites) fissure products, in what was ultimately a vain attempt to determine whether any significant time elapsed during either eruption.

The combination of multiple young erupted lavas exhibiting a wide range of composition, together with the presence of a variety of included cognate magmatic materials (table 1), has provided an unusual opportunity to understand magmatic processes at the volcano. Quenched magmatic inclusions (QMI) and inclusions with cumulate textures were found in more than half of the late Holocene lavas. In addition to evidence for intrusive events from the physical presence of magmatic inclusions, complex multi-stage magmatic histories are recorded within the lava flows in less obvious ways, including compositional zonation and mineralogical evidence (Grove and Donnelly-Nolan, 1986; Grove and others, 1988; Grove and others, 1997; Kinzler and others, 2000). Compositional data plotted in figure 5 compare late Holocene lavas and their cargoes of inclusions to the overall range of compositions at Medicine Lake volcano. It is apparent that magmatic materials brought to the surface in the late Holocene both overlap, and are distinguishable from, the earlier erupted materials. 

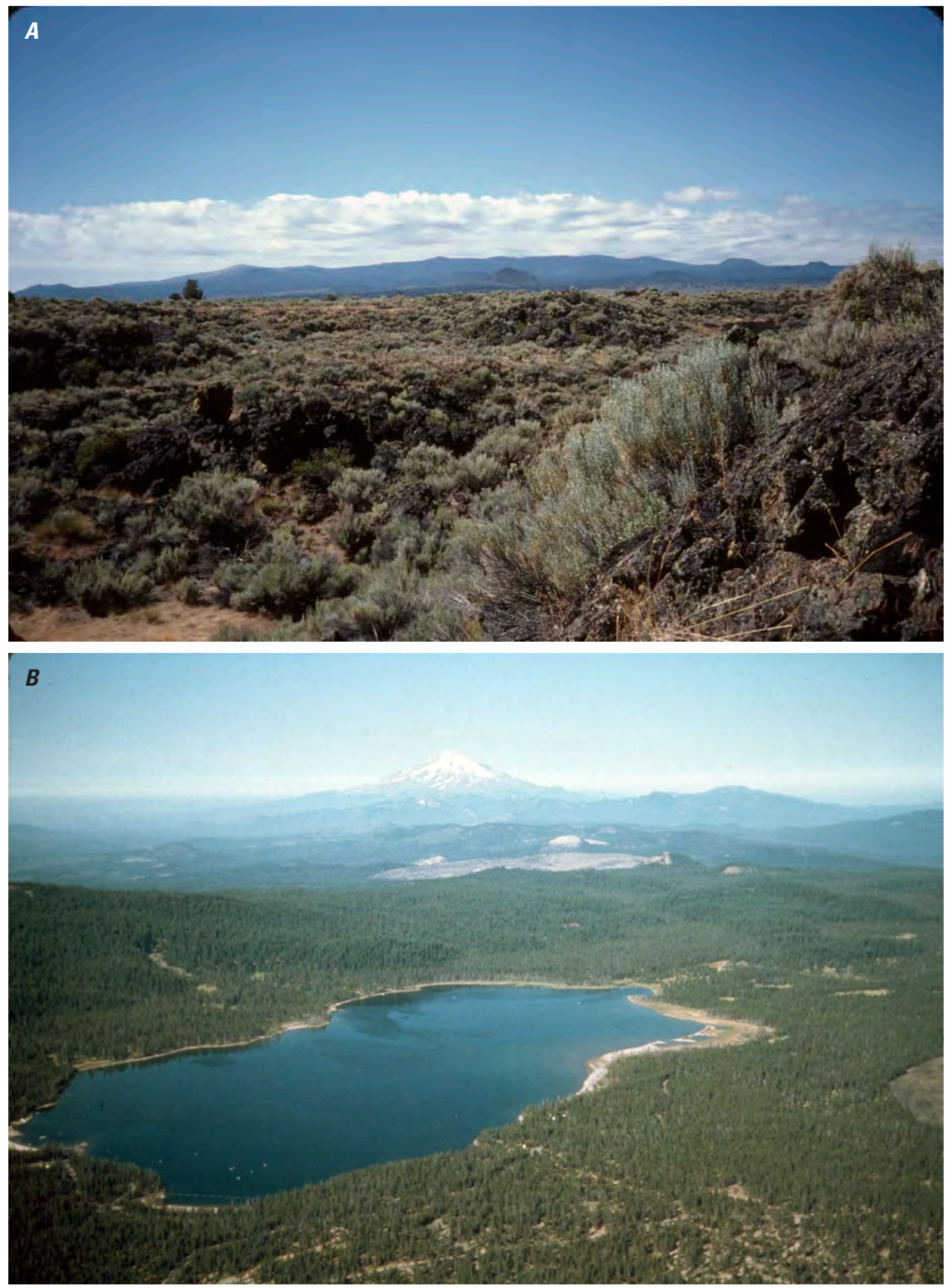

Figure 2. Photographs showing $(A)$ view south across basaltic lava in Lava Beds National Monument toward the main edifice of Medicine Lake volcano, and $(B)$ aerial view of Medicine Lake in the central caldera of the volcano. This namesake lake is about $2 \mathrm{~km}$ long. On the distant horizon is the snow-covered peak of Mount Shasta, located about 55 $\mathrm{km}$ to the west-southwest; treeless gray area beyond Medicine Lake is late Holocene Little Glass Mountain. 


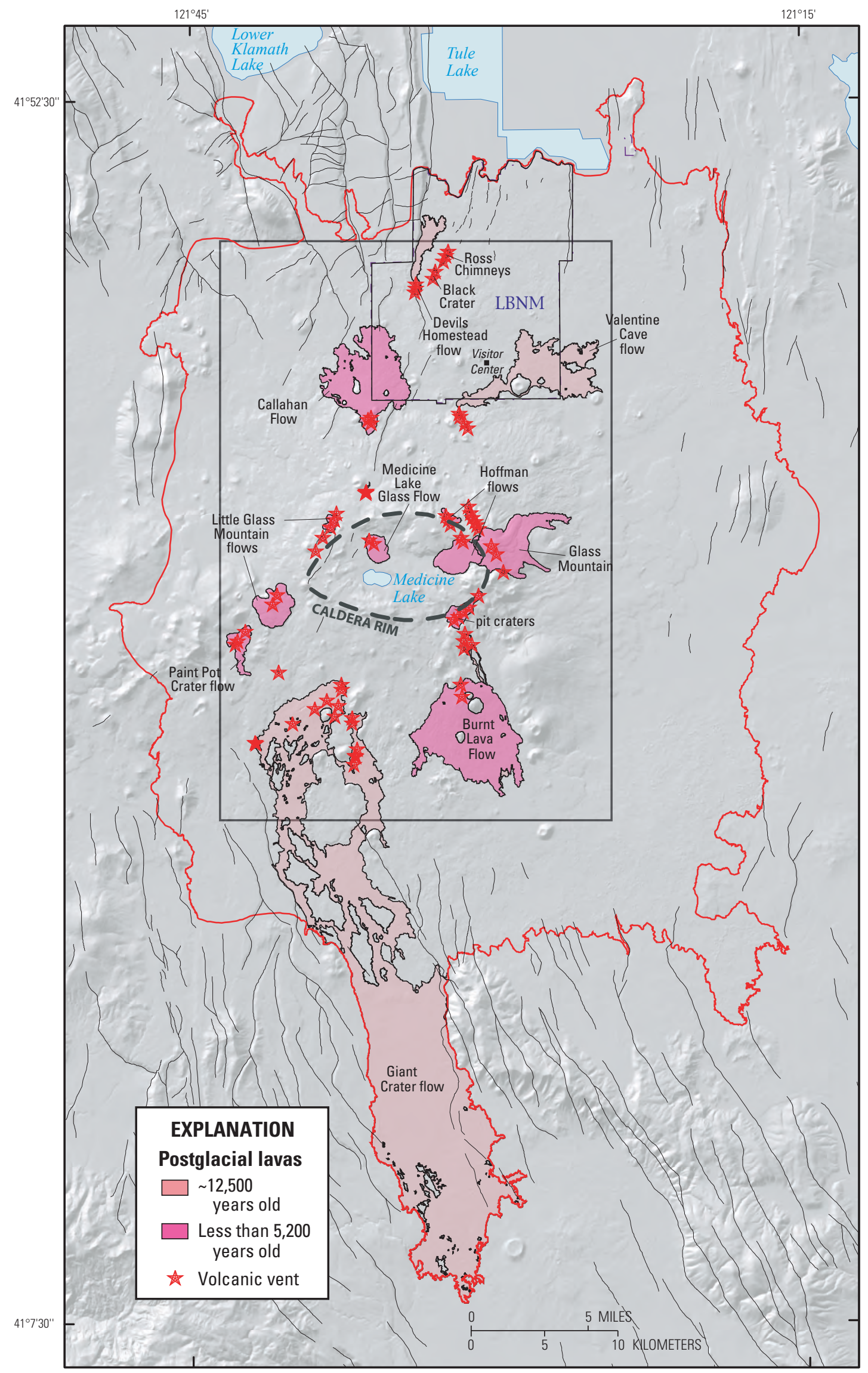

Figure 3. Shaded relief map of Medicine Lake volcano adapted from Donnelly-Nolan and others (2007). Approximate location of caldera rim, dashed black line; early postglacial lavas $\sim 12,500$ years old, light pink; late Holocene lavas $\sim 5,200$ years old and younger, dark pink; faults, thin black lines; Lava Beds National Monument on north flank of the volcano, LBNM. Box is area shown in figure $4 A, B$. 
$\boldsymbol{A}$

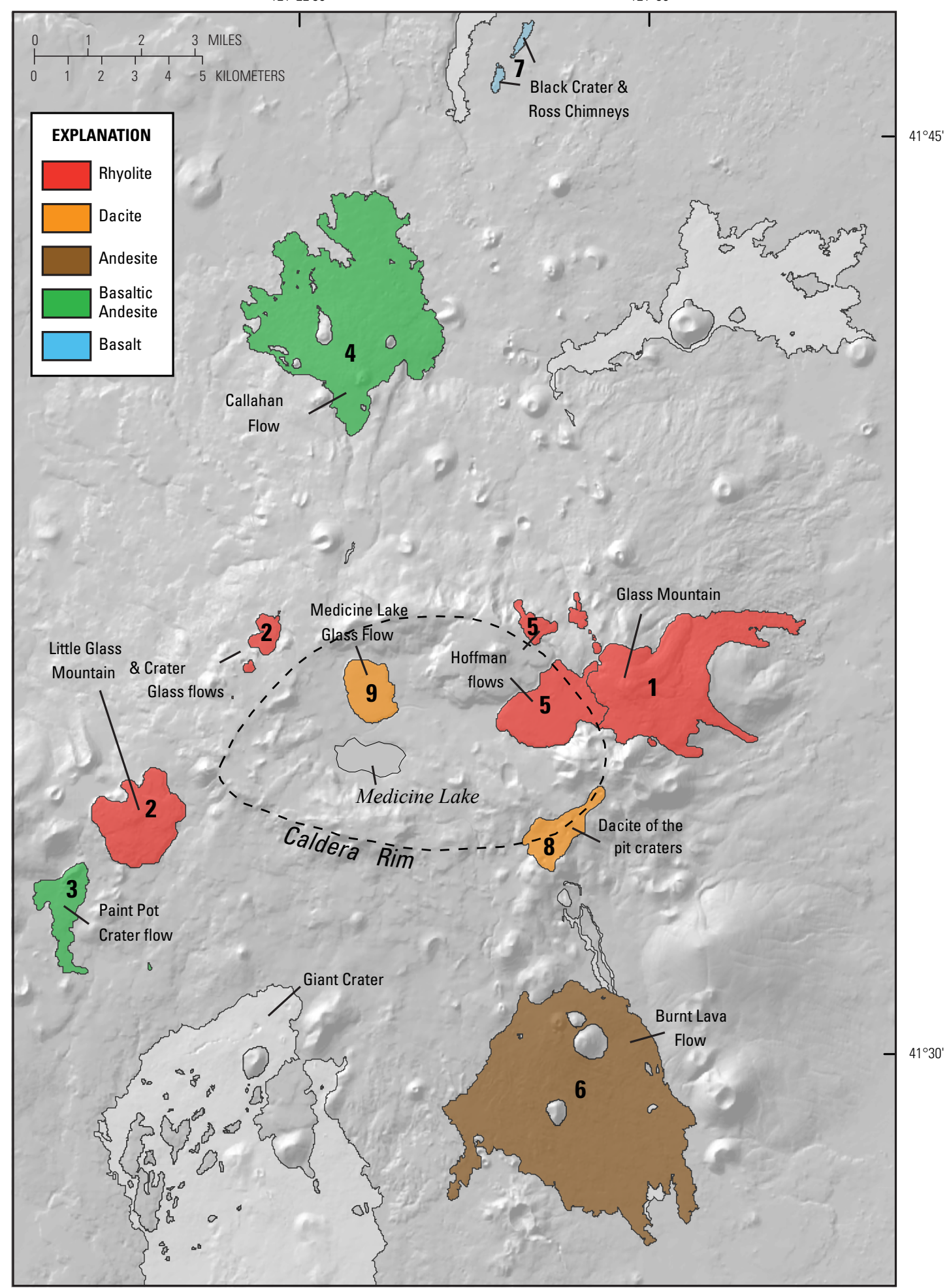

Figure 4. Maps featuring Holocene lavas at Medicine Lake volcano (adapted from Donnelly-Nolan and others, 2007). Area of coverage is indicated by box on figure 3. $(A)$ Map showing distribution of late Holocene lavas by composition; in weight percent $\mathrm{SiO}_{2}$, basalt is $<53$, basaltic andesite 53-56.9, andesite 57-62.9, dacite 63-69.9, and rhyolite $>69$. Light gray areas are $~ 12.5$-ka lavas. Numbers 1 through 9 identify late Holocene eruptive units from youngest (1) through oldest (9); (B) Late Holocene lavas shaded by eruptive episode. Crosses are vent locations, red for late Holocene, black for the 12.5-ka lavas. Unit symbols are from Donnelly-Nolan (2010); rhyolite of Glass Mountain, rgm; rhyolite of Little Glass Mountain, rlg; basaltic andesite of Paint Pot Crater, mpp; basaltic andesite of Callahan Flow, mcf; rhyolite of Hoffman flows, rh; andesite of Burnt Lava Flow, abl; basalt of Black Crater and Ross Chimneys, bbr; dacite of pit craters, dpc; dacite of Medicine Lake Glass Flow, dm. 


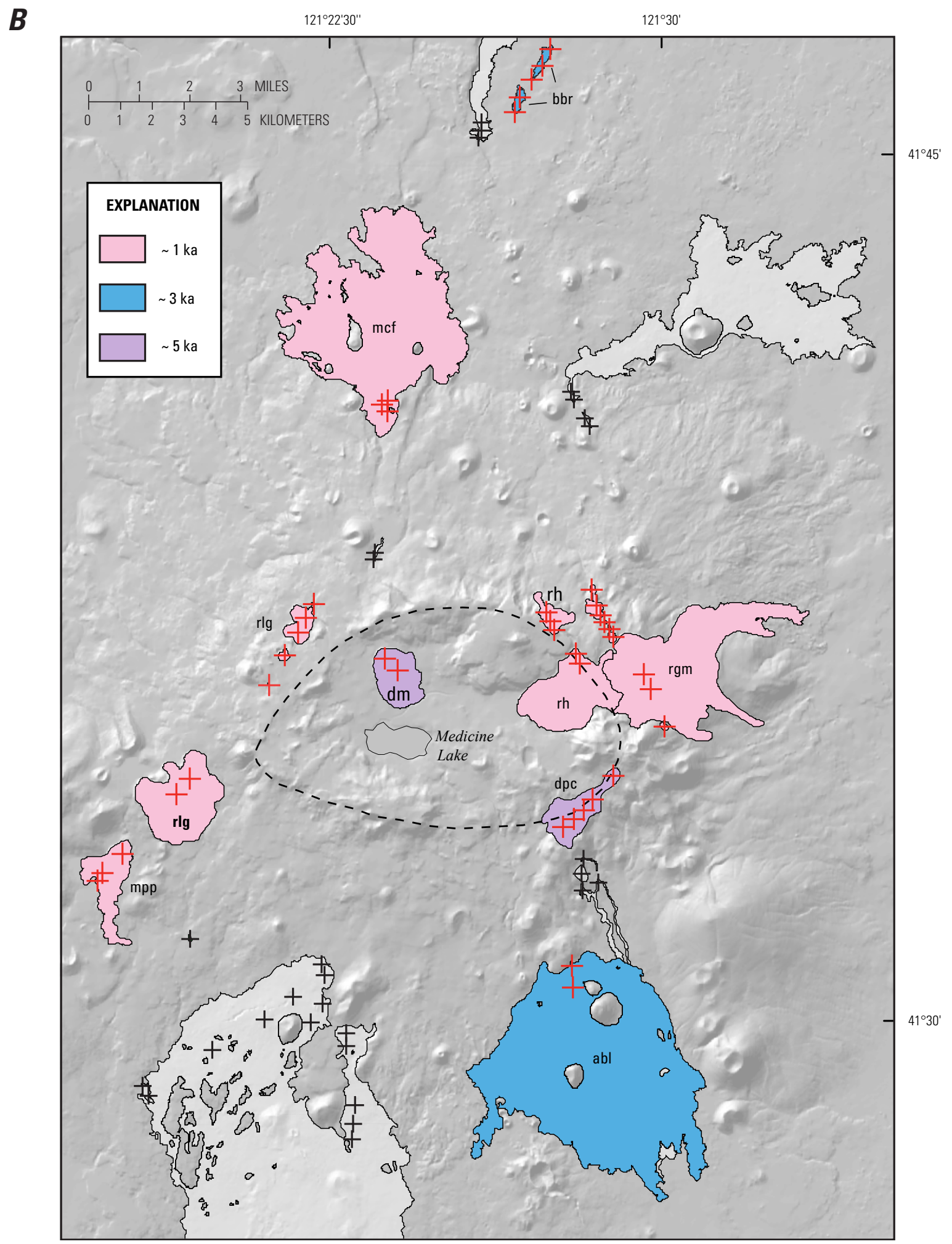

Figure 4.-Continued 
Magmatic inclusions were absent in the early rhyolitic lavas of the volcano (Donnelly-Nolan and others, 2008) and relatively scarce until the late Holocene. Chemical analyses of the analyzed inclusions that were found in older lavas are also listed in table 1.

Five of the nine late Holocene lava flows also brought plutonic inclusions, mostly granitic, but also gabbroic and dioritic, to the surface (table 2, online only). Granophyric textures in some of the granitic inclusions suggest shallow depths of origin. Dating of zircons from selected granitic inclusions yielded ages between $\sim 300 \mathrm{ka}$ and late Holocene, indicating that they are not fragments of older crust (Lowenstern and others, 2000; Lowenstern and others, 2003). One
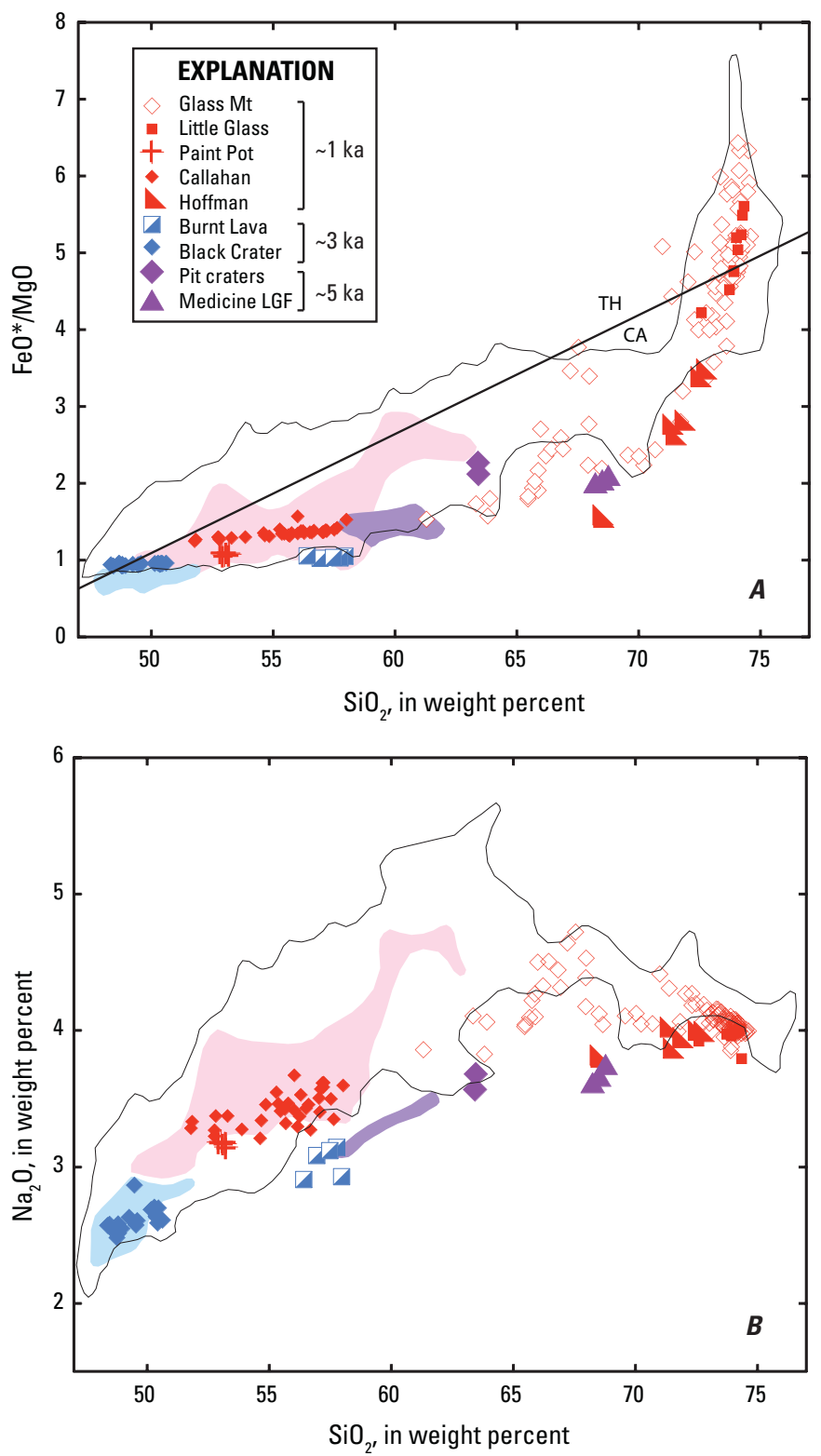

granodiorite sample collected during geothermal drilling in the MLV caldera also gave an age of $\sim 300 \mathrm{ka}$. Petrologic studies (for example, Grove and others, 1988; Grove and others 1997) indicate that assimilation of granitic material has played a significant role in generating evolved compositions at MLV.

The late Holocene lava flows at MLV can all be accessed by road and, with a few exceptions, have little or no tephra cover and typically only a limited tree cover. The abundance of youthful lavas was noted in early geologic work by Peacock (1931) and Powers (1932). Anderson (1933) focused initially on Glass Mountain and subsequently published an article about the volcano as a whole with an accompanying geologic map (Anderson, 1941). Additional work was done in the 1970s
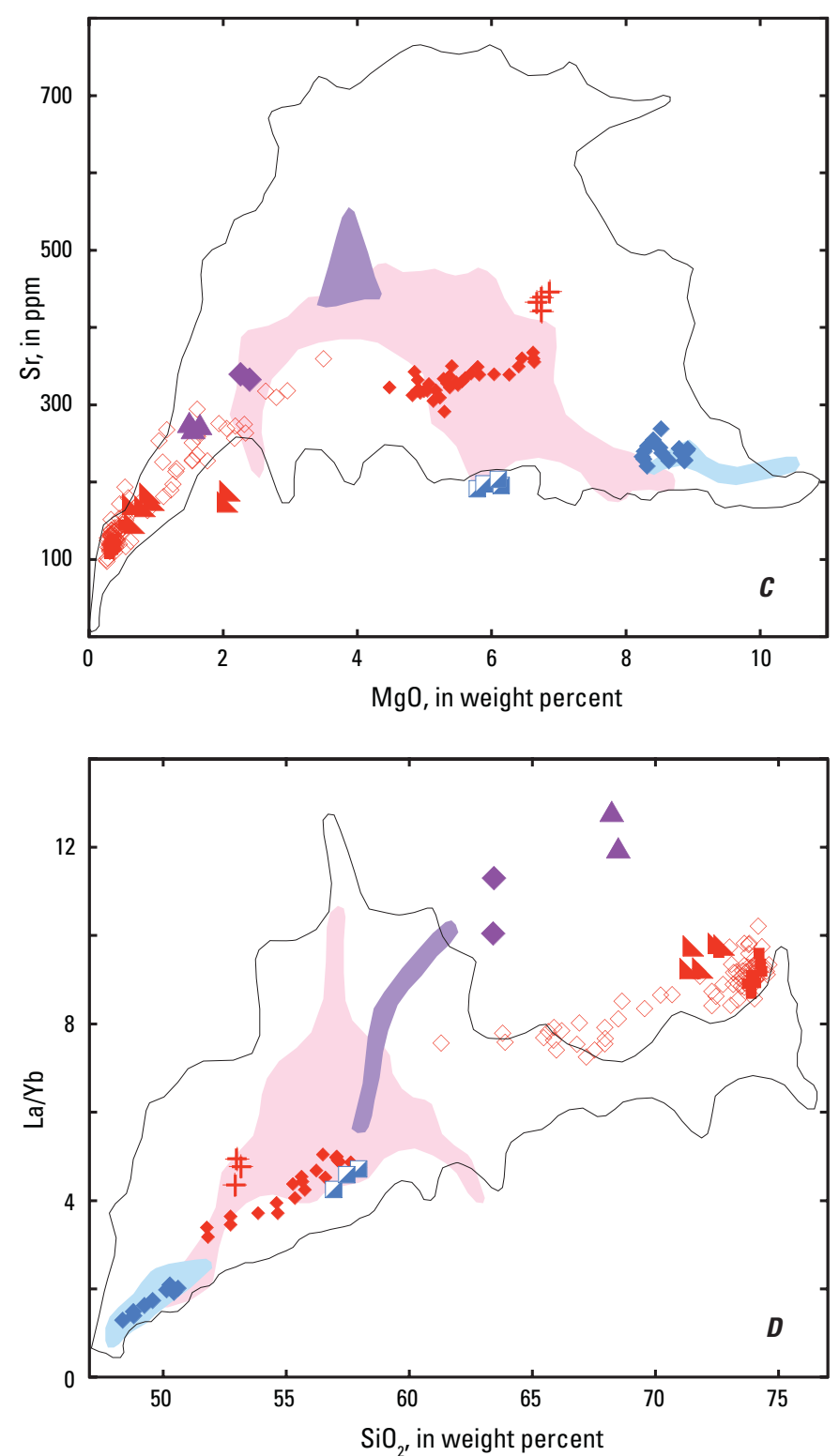

Figure 5. Plots showing chemical composition of late Holocene lavas and magmatic inclusions compared to the range of all other lavas erupted from Medicine Lake volcano (black outline). Symbol colors indicate eruptive episode (see figure $4 B$ and labeled brackets) with colored fields indicating the range of inclusion compositions for those episodes. Black line in $(A)$ separates fields designated as tholeiitic (TH) and calcalkaline (CA) by Miyashiro (1974). 
and 1980s by Condie and Hayslip (1975), Eichelberger (1975, 1980, 1981), Mertzman and Williams (1981), and Fink and Pollard (1983), among others. A comprehensive list of previous research is available in Donnelly-Nolan (2010). Beginning in the early 1980s, T.L. Grove and colleagues began a series of detailed petrologic studies, several of which focused on the late Holocene lavas (Grove and others, 1982, 1988, 1997; Gerlach and Grove, 1982; Grove and Donnelly-Nolan, 1986; Kinzler and others, 2000). Updated geologic studies include Donnelly-Nolan and others $(2007,2008)$ and the new detailed geologic map (Donnelly-Nolan, 2010).

This publication is focused on understanding the nature and frequency of late Holocene magmatic activity at MLV. New data and interpretive studies of individual eruptive events will be presented along with summaries of pertinent published geologic, geochemical, and petrologic information. Tectonic and geophysical constraints on the magma system will also be discussed. We begin with the most recent eruption, the 950 -yr-old Glass Mountain eruption that produced the largest Holocene rhyolitic lava flow in the Cascades volcanic arc, where rhyolitic volcanism has been relatively rare.

\section{The 1-ka Episode}

In the most recent volcanic episode at Medicine Lake volcano, five eruptions took place over an interval of $<300$ years from $\sim 950$ years ago to $\sim 1,230$ years ago (DonnellyNolan and others, 2007). These included the three late Holocene rhyolites plus two interspersed mafic eruptions. The
Glass Mountain and Little Glass Mountain eruptions occurred half a century apart in time and $16 \mathrm{~km}$ in distance from fissures on opposite sides of the caldera. On trend with Little Glass Mountain, but more than a century earlier in time, was the basaltic andesite of Paint Pot Crater, so named because of the later deposit of Little Glass Mountain white pumice on the black and red cone (fig. 6). Just prior to this mafic eruption, the compositionally zoned andesite-to-basalt Callahan Flow erupted on the north flank of the volcano. The earliest eruption in this episode took place when the rhyolitic Hoffman flows erupted along a northwest-trending fissure parallel to, and one $\mathrm{km}$ west of, the subsequent Glass Mountain fissure. The total estimated volume produced during this episode was $1.85 \mathrm{~km}^{3}$, and covered an area of $\sim 54 \mathrm{~km}^{2}$.

\section{Glass Mountain}

Originally known as Big Glass Mountain (Peacock, 1931), this spectacular lava flow is the largest Holocene rhyolitic lava flow in the United States. The main vent dome, Glass Mountain (fig. 7), rises to an elevation of 2,323 m, less than $100 \mathrm{~m}$ lower than the highest point on the volcano. Draped over the steep eastern slope of the volcano (fig. 8), the easternmost tongues reach elevations as low as 1,478 $\mathrm{m}$. The jagged surface of the lavas (fig. 9), nearly barren of vegetation, stands in marked contrast to the surrounding forested terrane. Viewed from the east, halfway across the main lava flow, an 80-m-high front of black rhyolitic obsidian glistens in the sunlight, atop a stony dacitic lava erupted earlier in the same continuous, compositionally zoned eruption. At least 15 vents along the

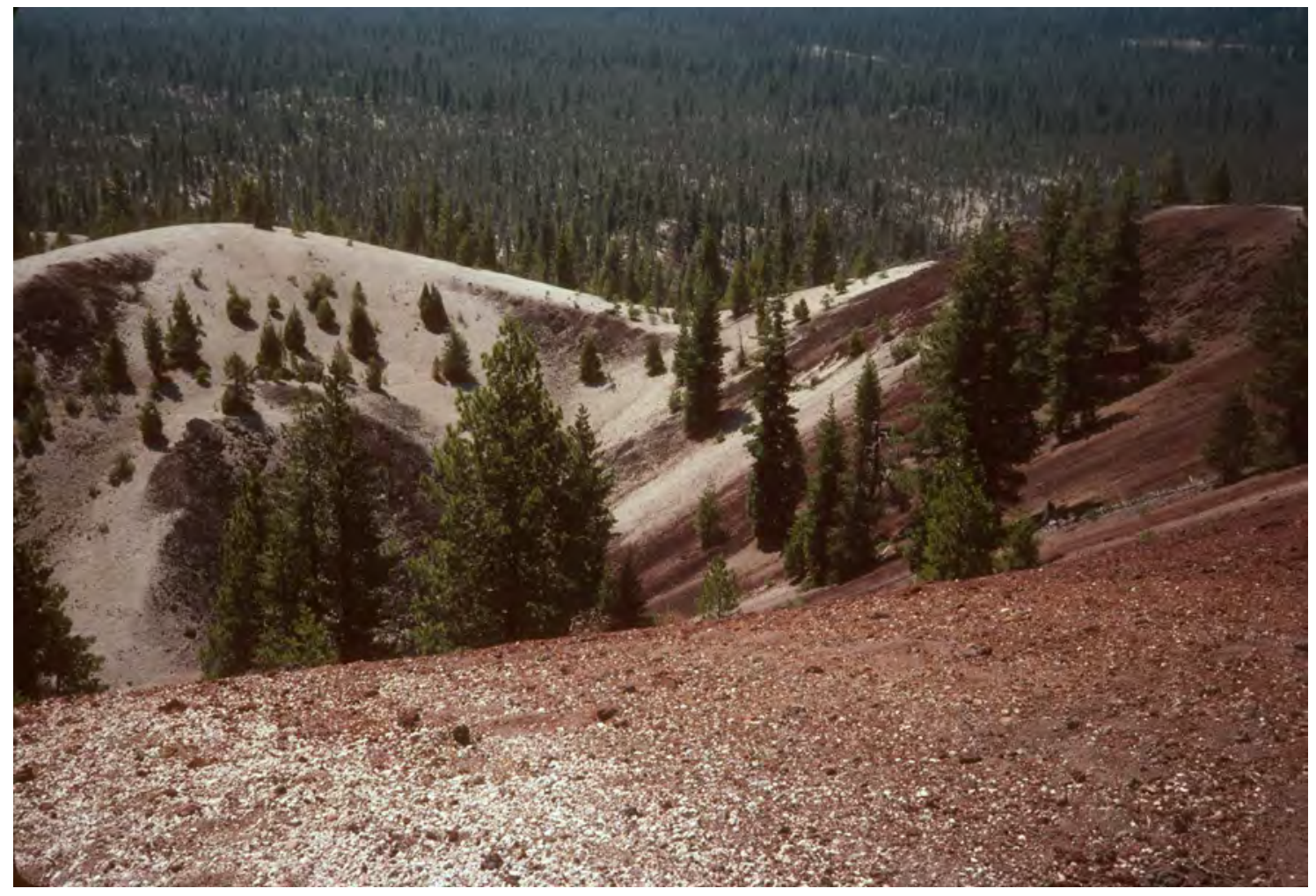

Figure 6. Photograph taken from rim of late Holocene Paint Pot Crater showing the black and red coloring of this youngest mafic cinder cone at Medicine Lake volcano mantled by white pumice from the adjacent and slightly younger Little Glass Mountain eruption. 


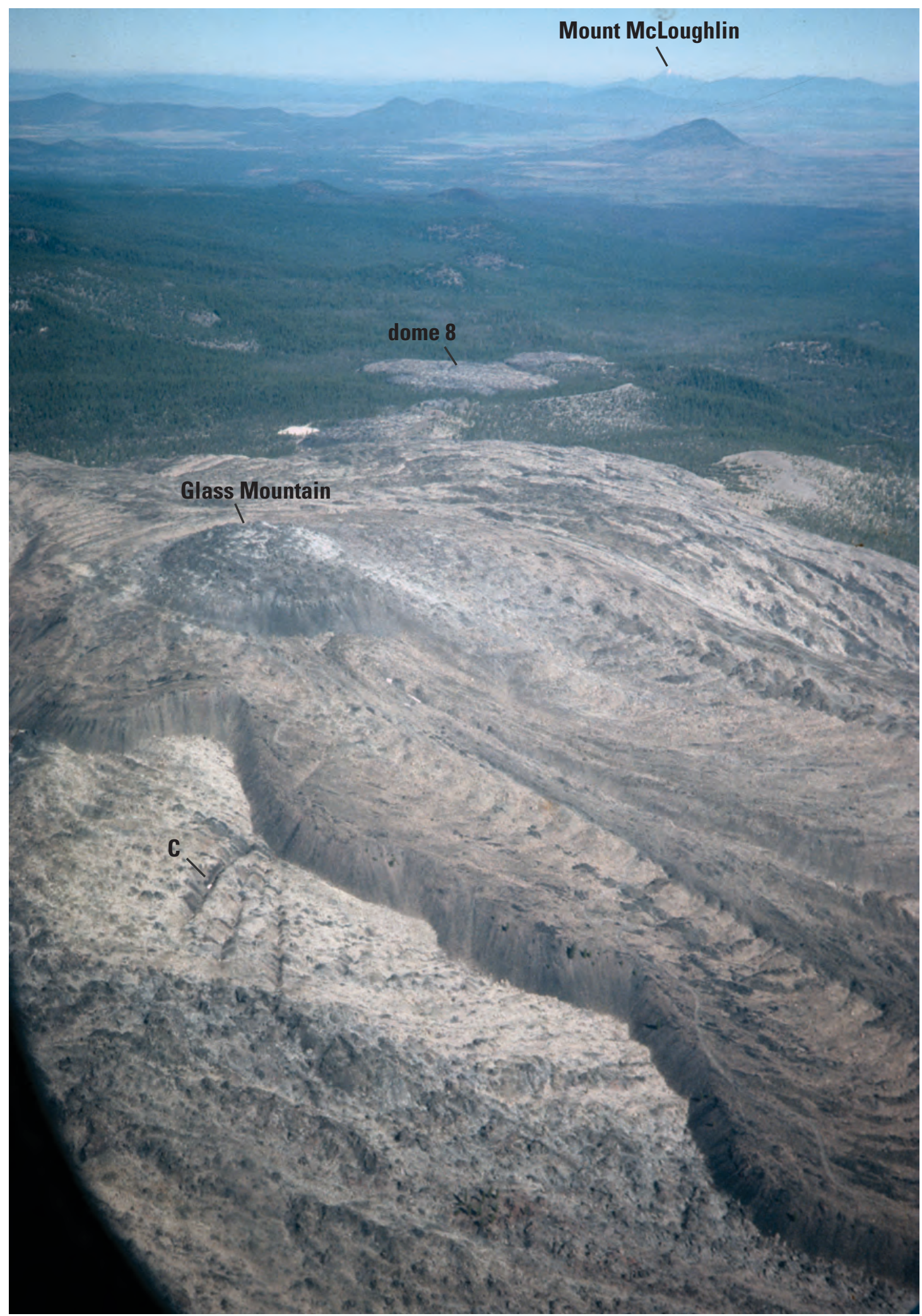

Figure 7. Aerial view looking northwest across the upper part of the Glass Mountain flow. The last-erupted rhyolite of this youngest eruption at Medicine Lake volcano forms the prominent dome of Glass Mountain proper. Toward the viewer, south of the dome is the high margin of the last rhyolite lava flow. Just south of that high margin is a set of three north-trending cracks, the uppermost of which (labeled C) provided access for paleomagnetic sampling. Beyond the far edge of the main flow are the treeless northern small domes along the vent fissure. The distance from the dome of Glass Mountain, to dome 8 , is $\sim 2.5 \mathrm{~km}$. 


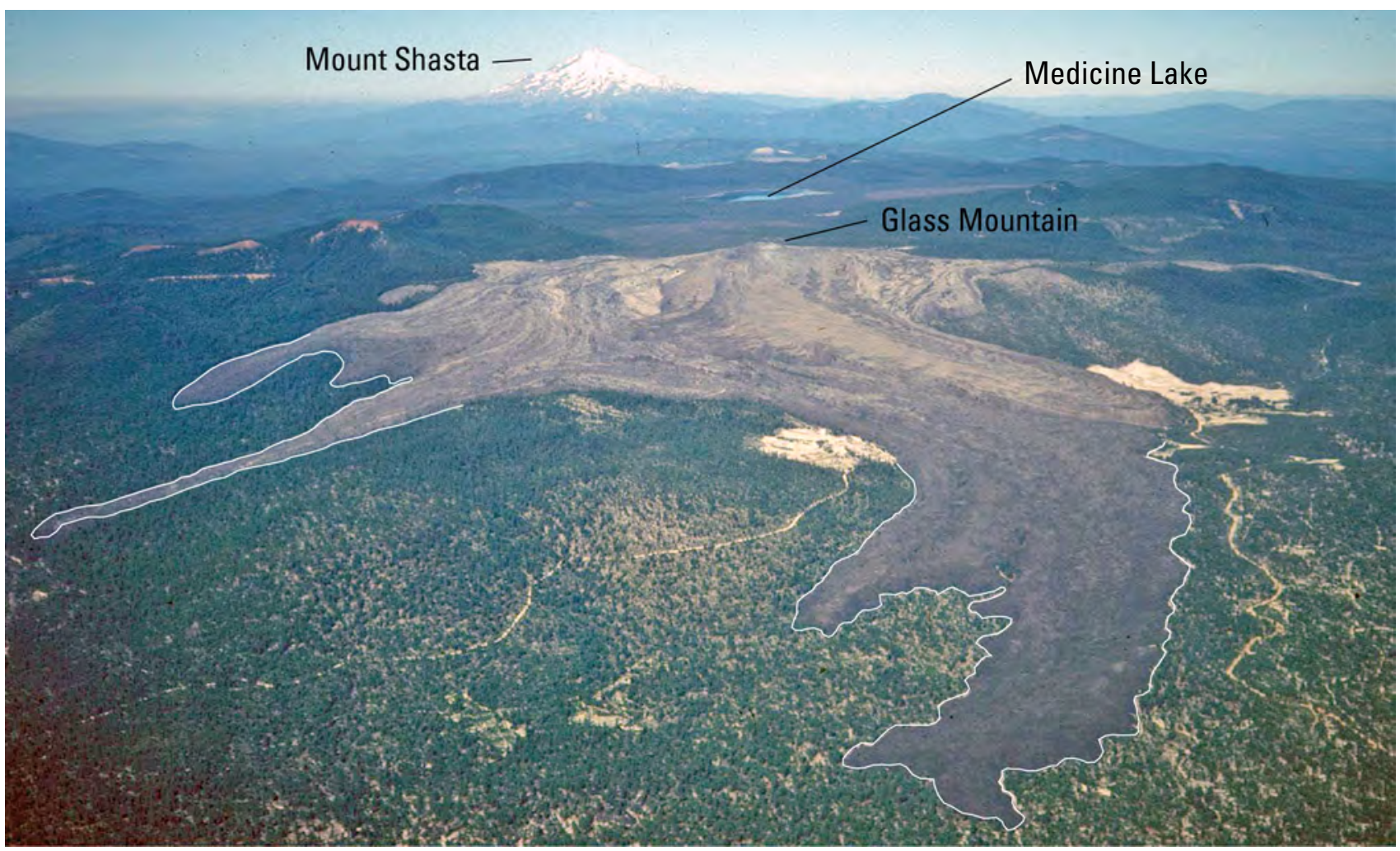

Figure 8. Aerial view looking west-southwest across the central part of Medicine Lake volcano toward Mount Shasta dimly seen through haze on the horizon. Early dacitic lobes of the Glass Mountain flow are outlined in white for visibility. Beyond Glass Mountain is the broad shallow bowl of the 7 by 12-km caldera with Medicine Lake near the center. The distance from Medicine Lake to Mount Shasta is $\sim 55 \mathrm{~km}$. Adapted from figure 3 in Donnelly-Nolan and others (2008).

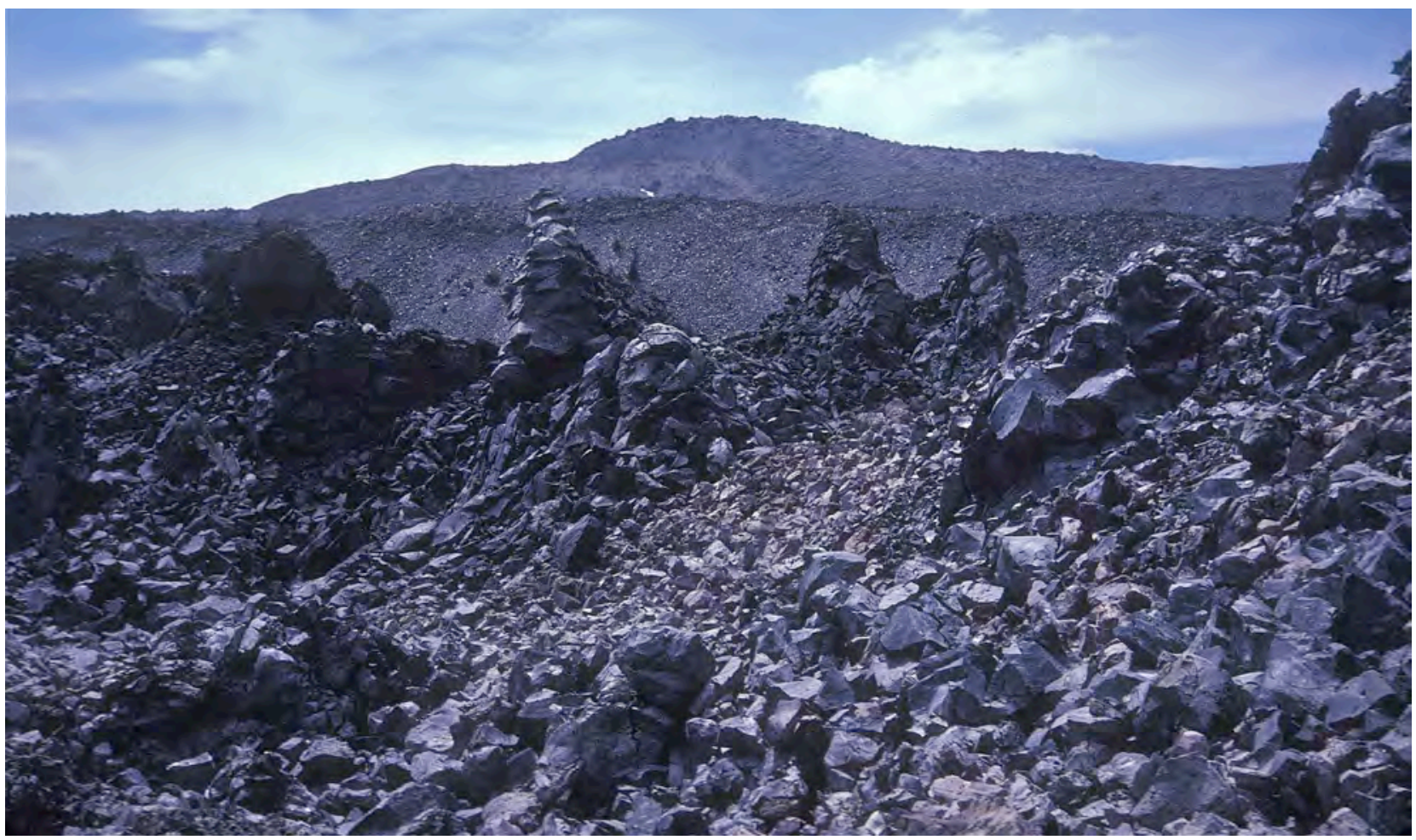

Figure 9. View westward toward the dome of Glass Mountain from eastern zone of mingled and spine-covered rhyodacitic lava. Photograph shows typical chaotic and blocky flow surface. 
5-km-long vent fissure produced $\sim 1 \mathrm{~km}^{3}$ total of lava, consisting dominantly of rhyolite with subordinate dacite and minor andesite. The flows have an overall compositional span of 74.6-61.3 weight percent $\mathrm{SiO}_{2}$. Included within the host lava are a variety of quenched magmatic inclusions (QMI), cumulate magmatic inclusions, and rare plutonic inclusions. About 10 percent of the total volume consists of early rhyolitic tephra (Heiken, 1978). Along the fissure to the north and south of the main flow, some near-vent tephra has welded to form agglutinate deposits adjacent to the small domes. The total area covered by the main flow and the adjacent small domes (fig. 10) along the north-northwest-trending fissure (domes 1 through 10 to the north, one to the south) is $\sim 14 \mathrm{~km}^{2}$, the vast majority of it in the main flow.
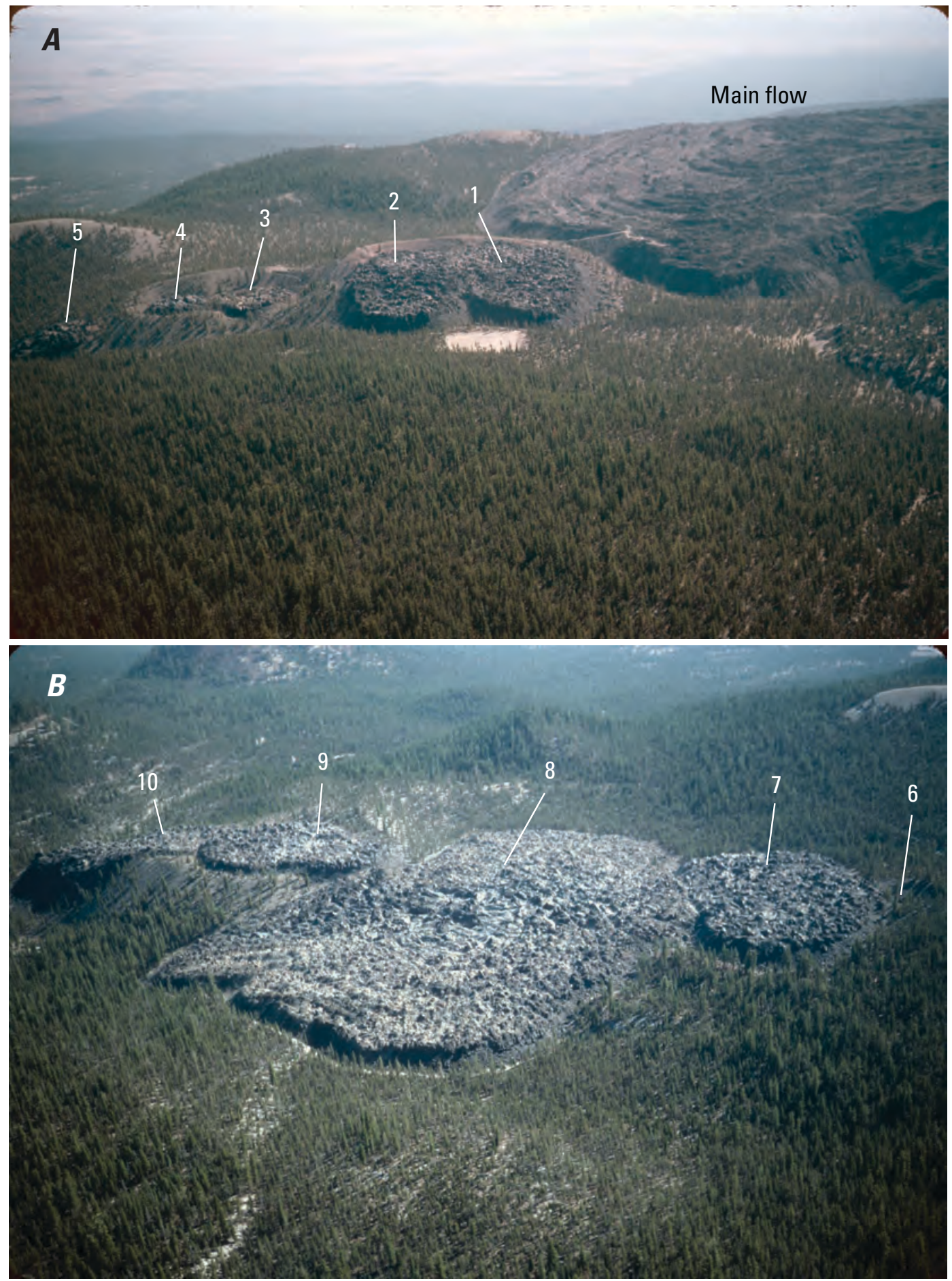

Figure 10. Views east across the northern Glass Mountain vent fissure show $(A)$ the north edge of the main flow with domes 1 through 5 labeled; the open area in front of domes 1 and 2 is a former drill pad for a geothermal test well; and $(B)$ domes 6 through 10 . Note that photo $(B)$ is a closer view than photo $(A)$. 


\section{Previous Work}

Glass Mountain attracted the early attention of researchers, including Peacock (1931), Powers (1932), and Anderson (1933). Both Powers (1932) and Anderson (1933) recognized the presence of rhyolite and dacite in the main Glass Mountain flow, along with the presence of inclusions. They obtained chemical analyses of the lava and Anderson also listed one analysis of an inclusion. Both described the intimate relationship and sharp contacts between the dacite and bands of rhyolitic obsidian. Anderson (1933, p. 498) further concluded that "...obsidian was being extruded as dacite left the vent, for otherwise it is difficult to explain the presence of bands of rhyolite obsidian in the front of the dacite tongues." Anderson's map (1933, his fig. 3) shows the approximate distribution of rock types. Subsequently, Eichelberger (1975) produced a more detailed map of the main Glass Mountain flow and demonstrated that there was overall eruptive continuity from dacite through rhyolite lava. Eichelberger recognized the complexity exhibited in the multiple lobes of lava and mapped the distribution of subunits that were described as "rhyolite with inclusions" and "banded lava", the latter being zones of physically mingled compositions. Eichelberger also argued against the idea that separate and internally homogeneous dacite and rhyolite obsidian magma compositions were erupted simultaneously. The same year, Condie and Hayslip (1975) established the extent of compositional variation within the rhyolite and dacite, explaining that the dacites formed "...by shallow mixing of a hybrid magma (composed of varying amounts of andesite and dacite) with rhyolite prior to and during eruption." Eichelberger $(1980,1981)$ revised his previous interpretation that the mafic inclusions were lithic fragments and instead concluded that they represented a basaltic foam generated by intrusion of mafic magma into a shallow rhyolitic magma chamber. In Eichelberger's 1981 model, vesiculation of the basalt was followed by mixing and eruption.

Subsequent to Eichelberger's 1975 study, a limited number of chemical analyses of Glass Mountain host lavas and inclusions were presented in Grove and Donnelly-Nolan (1986) and in Grove and others (1997).

\section{The Glass Mountain Eruption}

The Glass Mountain eruption began with explosive activity along the length of the vent fissure, generating tephra deposits (fig. 11) that have, in part, been exposed by mining activities. Tephra samples collected north and south of the main flow contain $>72.3$ weight percent $\mathrm{SiO}_{2}$, with most analyses $>73.5$ weight percent (table 1 ). Near the vents, adjacent to northern domes 1-10, and adjacent to the southern small dome, coarse tephra was hot enough to weld, forming agglutinate deposits that are preserved surrounding and adjacent to most of the small domes. The deposits contain bombs that have pumiceous interiors surrounded by breadcrust rinds, as well as prismatically jointed blocks that were erupted and broke apart after cooling. At the main Glass Mountain vent, scoriaceous dacitic to andesitic blocks were also ejected and preserved in late near-vent agglutinate now buried by the main flow. These near-vent blocks are preserved scattered along linear bands of dominantly rhyolitic pumice breccia (Anderson, 1941) within the flow (fig. 12). The pumice breccia was described by Anderson (1933) as representing the remnants of the original pumice cone. The breccia consists of broken and jumbled pieces, from sand-size to several meters in length of welded agglutinate along with andesitic to rhyolitic pumice and prismatically jointed blocks. These narrow breccia zones can easily be recognized from a distance because, in contrast to the treeless flow rocks, they are host to a sparse growth of spindly and undernourished evergreen trees. Scattered andesitic to dacitic scoria samples collected from the dominantly rhyolitic pumice breccia contain 61.3 to 65.7 weight percent $\mathrm{SiO}_{2}$.

Emplacement of lava flows and domes began after the explosive eruptions ceased. The first lava to erupt in the main flow, as previously recognized by Anderson (1933) and Eichelberger (1975), was a phyric mixed dacite mingled with mafic blobs of quenched magmatic inclusions (QMI). The early dacite also entrained small volumes of aphyric rhyolite. As the eruption proceeded, rhyolite and dacite poured nearly a kilometer in vertical elevation down the steep eastern slope of the volcano. Shear zones developed between major lobes apparently traveling at different rates. Eruption of the mingled rhyolite-dacite lava was followed by rhyolite containing sparse QMI. The most voluminous, and most likely the last, lava to be erupted was aphyric, inclusion-free rhyolite that formed the bulk of the main flow, including the spine-covered dome of Glass Mountain itself that appears to have been the primary vent.

Glass Mountain lava flow and tephra compositions range in silica content from 61.3 percent to 74.6 weight percent. Chemical analyses of 102 lava and tephra samples are presented in table 1 . The generalized spatial distribution of lava compositions and the locations where samples were collected are shown on figure 13. The map was created using the chemical analyses together with field observations and aerial photographs. The new mapping and compositional data strongly support the idea (Anderson, 1933) that different compositions were erupting from the vent at the same time.

Field criteria for distinguishing rhyolitic lavas from dacitic lavas include luster (dull for dacite, glassy for rhyolitic obsidian), abundance of phenocrysts (more in dacite; fewer or none in rhyolite), and abundance of inclusions (common in dacite; few or none in rhyolite). Dacitic lavas ( $<70$ weight percent $\mathrm{SiO}_{2}$ ) typically exhibit up to 3 percent of $1-3 \mathrm{~mm}$ phenocrysts in hand specimen, with flow-aligned plagioclase more abundant than orthopyroxene and magnetite. Quenched magmatic inclusions (QMI) and crystal debris (plagioclase + olivine + clinopyroxene) from disaggregated inclusions are also commonly present in the dacite. Detailed petrographic descriptions of Glass Mountain lavas and inclusions can be found in Grove and others (1997). Rhyolitic lavas with more 


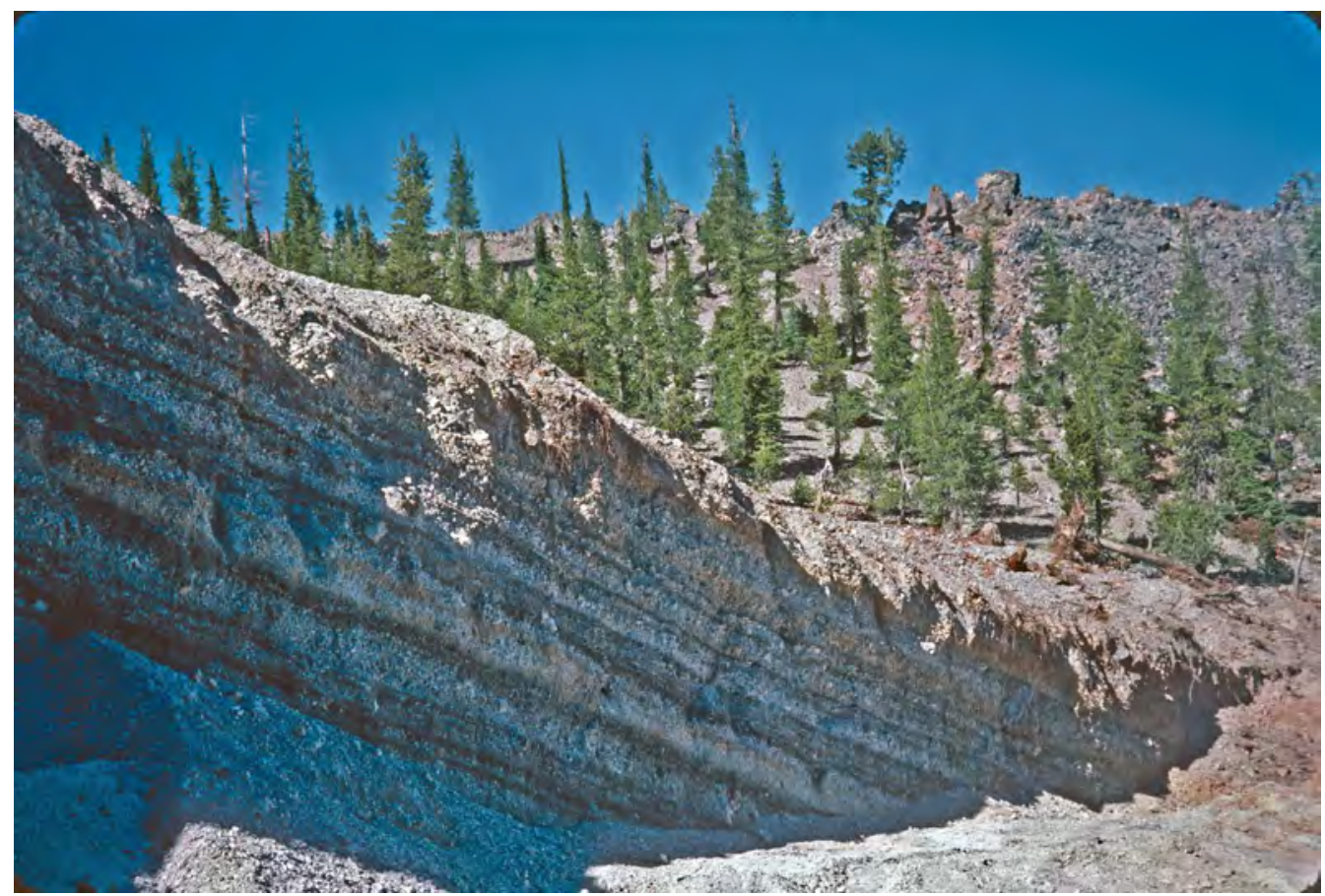

Figure 11. Photo of Glass Mountain tephra taken in 1987 during active quarrying adjacent to and east of dome 10 (in background).

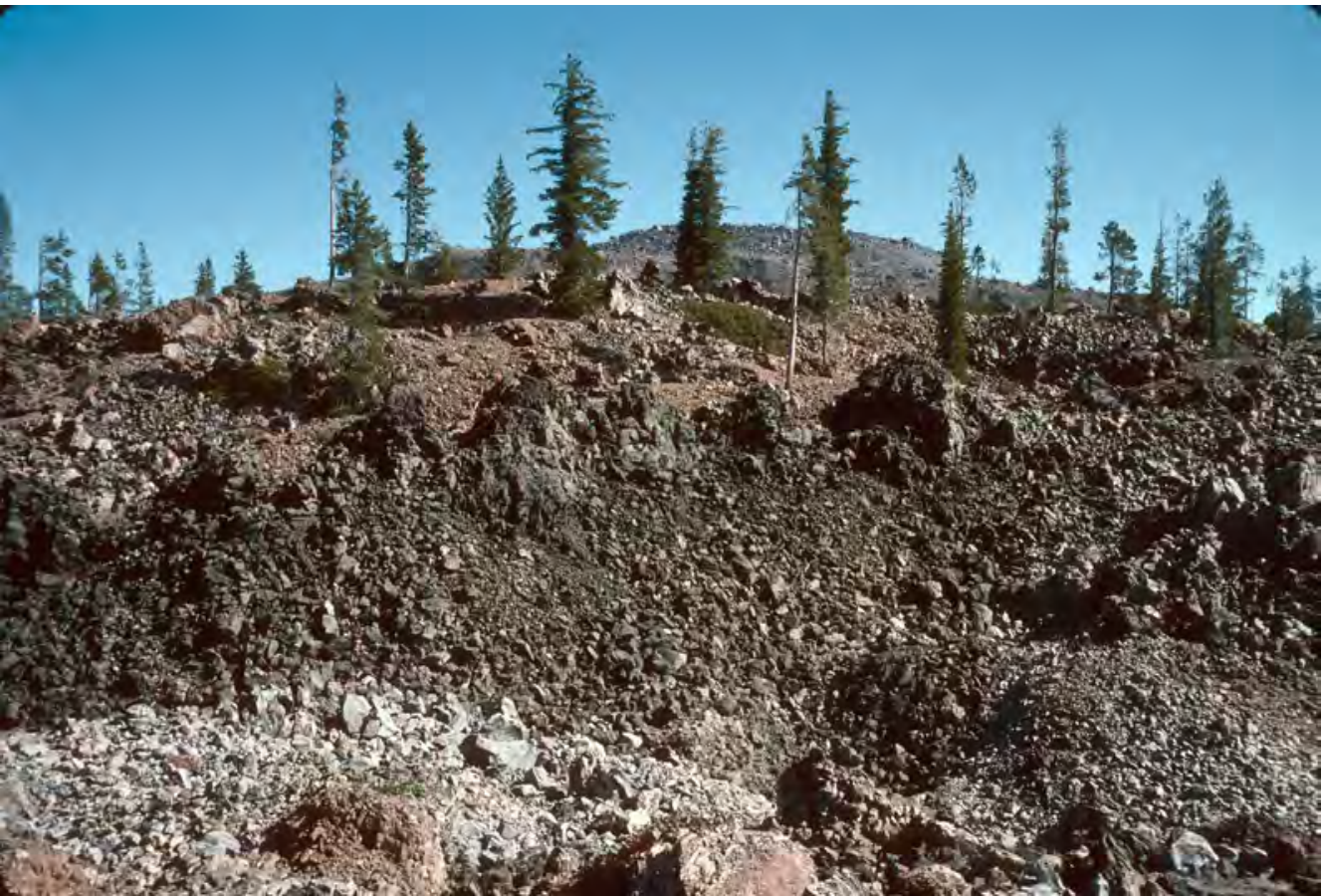

Figure 12. Photo shows elongate pinkish band of pumice breccia (Anderson, 1936), easily identified by the trees that grow in this zone of broken, brecciated, and in part oxidized pumice and lava. Anderson (1933) considered these zones to consist of near-vent pumice and agglutinate from a pumice cone material subsequently incorporated into the lava flow and dragged eastward.

than 73.5 weight percent $\mathrm{SiO}_{2}$ are aphyric; those with 7073.5 percent contain $1-2$ percent of $1 \mathrm{~mm}$ plagioclase and rare $1 \mathrm{~mm}$ orthopyroxene and magnetite. QMI are present in these lower-silica rhyolites, but they are much less abundant than in the dacitic lavas. Photomicrographs of selected thin sections from a range of lava compositions are shown in figure 14.

Two old bulldozer tracks, one from the south and another from the east, provide easily accessible foot traverses across parts of the main flow (fig. 13), although many samples were also obtained in less accessible areas. Where multiple compositions were obviously present, samples were collected to represent the maximum apparent difference in $\mathrm{SiO}_{2}$ content. A broad generalization derived from the mapping is that compositional variation on a scale of tens of meters is commonly gradational from dacite to rhyodacite to rhyolite. However, the mingling of bands of various compositions also took place at the scale of meters to centimeters to millimeters, and the definitions of subunits in the geologic mapping are therefore somewhat arbitrary. In some places, flow emplacement processes have caused one compositional type to overtop or flow across another, juxtaposing lava of very different $\mathrm{SiO}_{2}$ contents. One of the most complexly banded parts of the main 

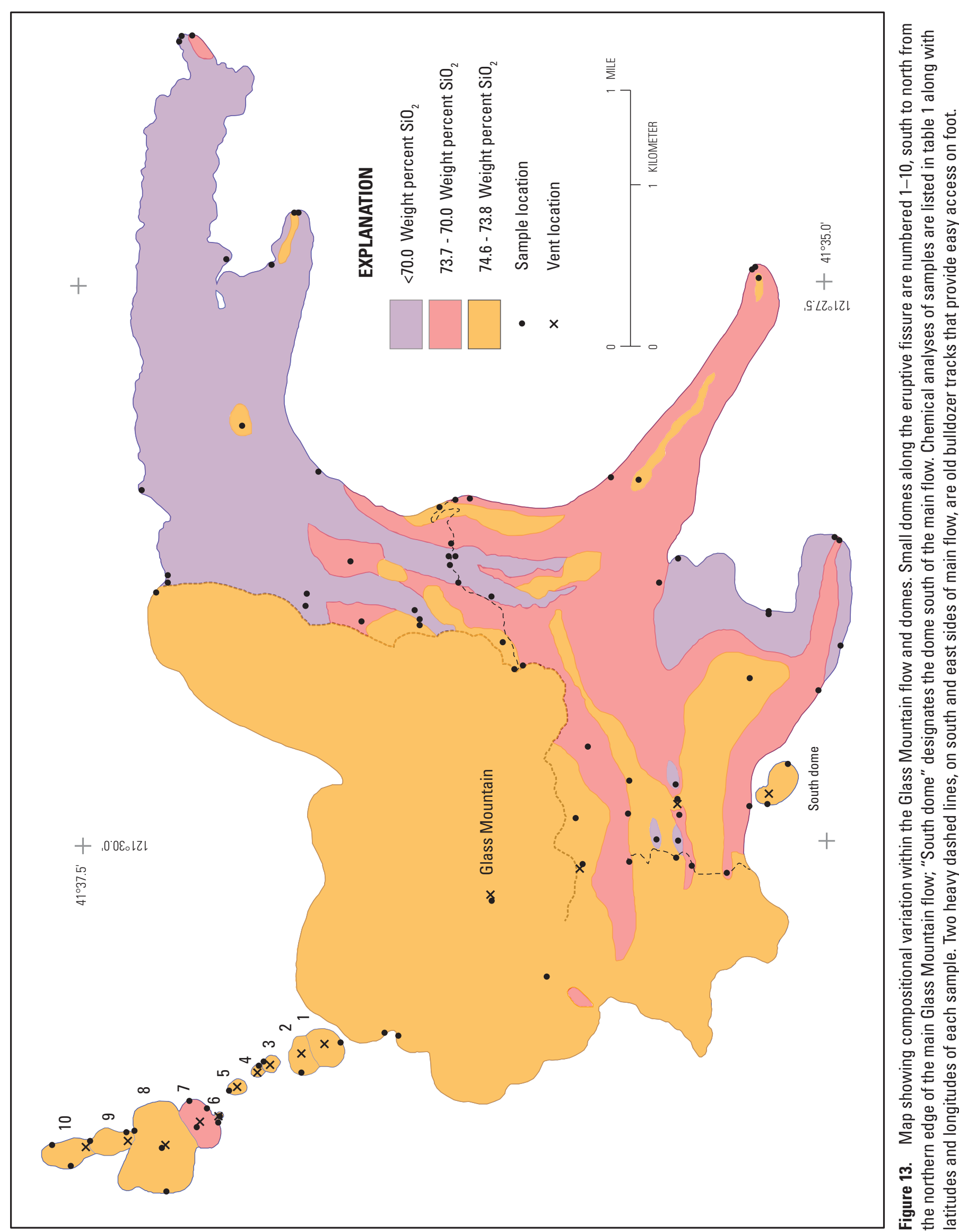

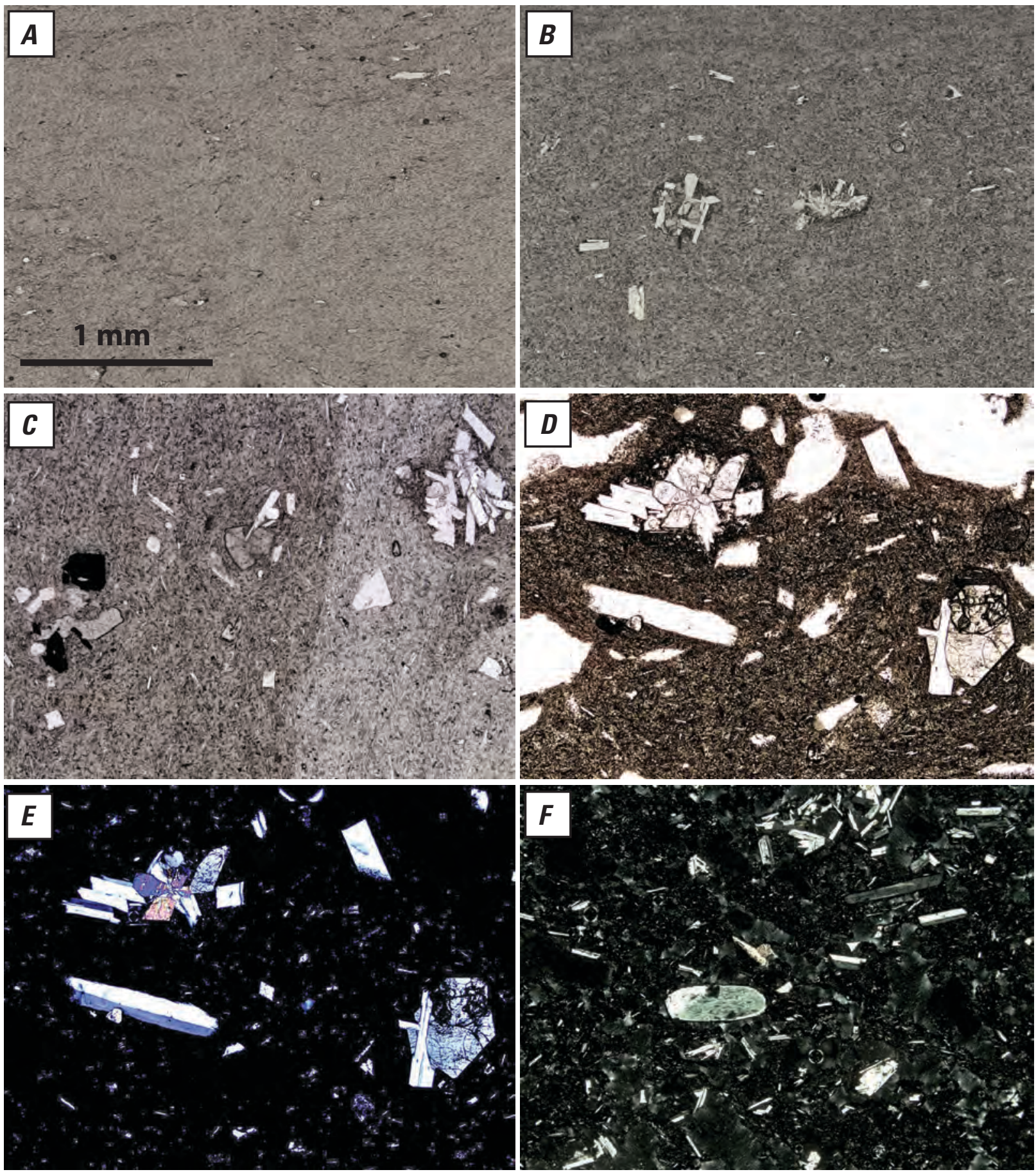

Figure 14. Photomicrographs of Glass Mountain lavas in order of decreasing silica content. $(A)$ 1406M (74.6 weight percent $\mathrm{SiO}_{2}$ ) aphyric obsidian displays faint foliation defined by tiny microlites; $(B)$ 1135M (71.7 weight percent $\mathrm{SiO}_{2}$ ) contains small crystal clots of plagioclase and orthopyroxene in glassy groundmass with scattered very small plagioclase; $(C) 1426 \mathrm{M}$ (68.6 weight percent $\mathrm{SiO}_{2}$ ) has microphenocrysts of orthopyroxene, magnetite, and plagioclase and one clot in a glassy groundmass that contains abundant discernible plagioclase laths; $(D, E)$ plane light and crossedpolarized light views of $1692 \mathrm{M}$ ( 65.6 weight percent $\mathrm{SiO}_{2}$ ) display microphenocrysts of plagioclase and orthopyroxene in murky groundmass with some vesicles and a limited amount of discernible plagioclase microlites; $(F)$ crossed-polarized light image of $1896 \mathrm{M}$ ( 61.3 weight percent $\mathrm{SiO}_{2}$ ) shows vesicular groundmass crowded with small plagioclase and a single rounded microphenocryst of orthopyroxene. All images are the same scale. Chemical analyses are in table 1. 


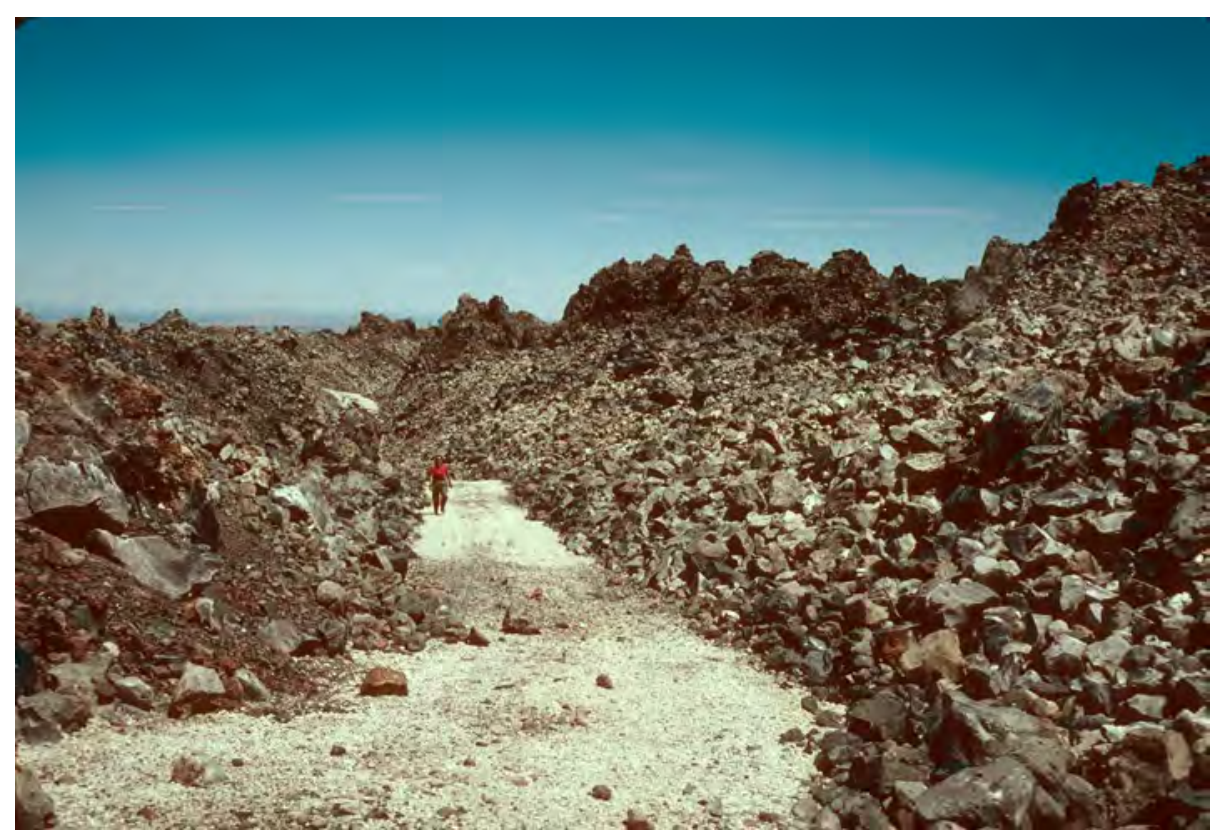

Figure 15. View looking east along old bulldozer road that extends across the eastern part of the main Glass Mountain flow. The road allows easy pedestrian access to some of the most mingled and rugged parts of the flow.

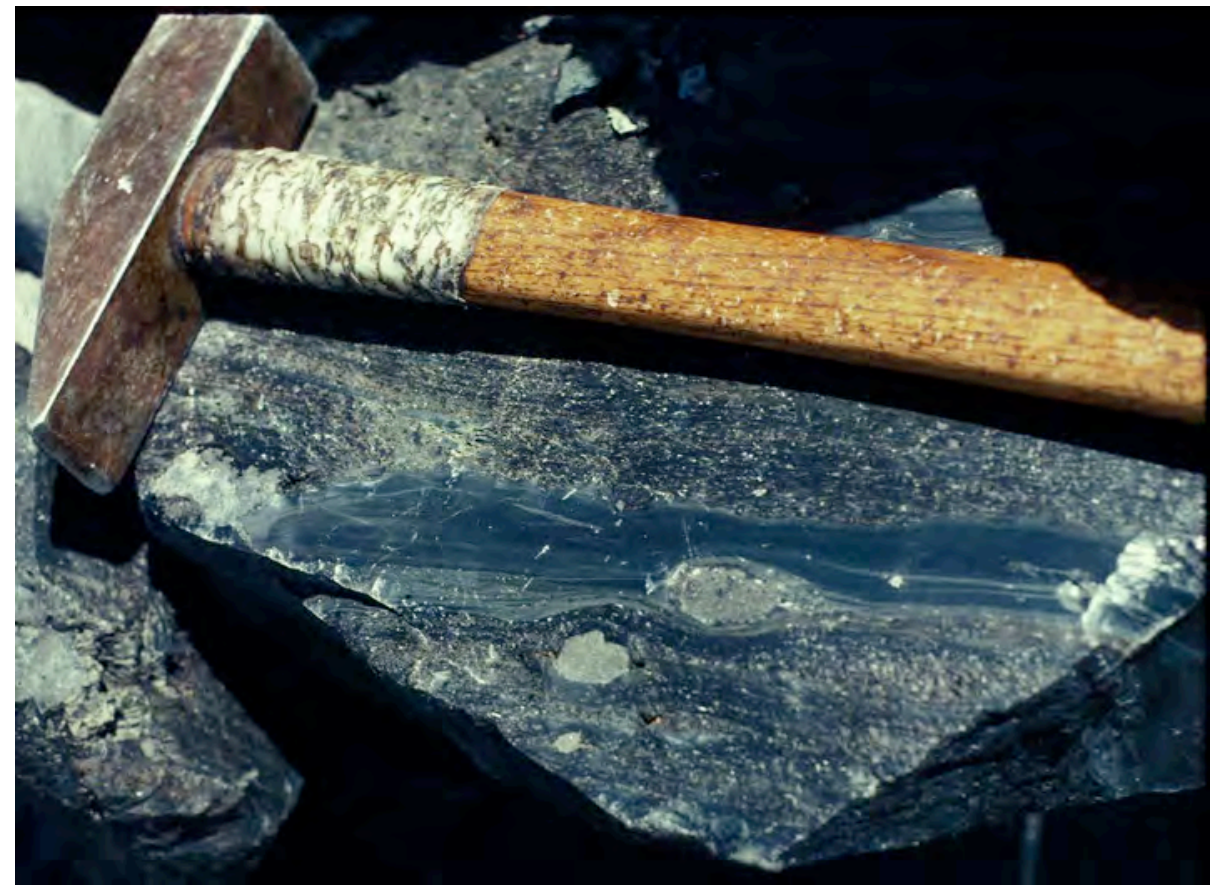

Figure 16. Photograph of a single block of Glass Mountain mingled lava, located along the east road, shows quenched magmatic inclusions, porphyritic (possibly mixed) dacite, and a band of aphyric rhyolitic obsidian. Hammer head is approximately $15 \mathrm{~cm}$ long.

flow is the east central portion traversed by the eastern bulldozer track (fig. 15). Mingling occurred in this area on scales from microscopic to hundreds of meters, and figure 16 shows one example with alternate bands of phyric dacite and aphyric rhyolitic obsidian, both of which have flowed around QMI. Samples 1683M-A (74.5 weight percent $\mathrm{SiO}_{2}$ ) and 1683M-B (68.5 weight percent $\mathrm{SiO}_{2}$ ) were collected in this same area of the flow from adjacent bands of dacite and rhyolite within a single block only $0.3 \mathrm{~m}$ across. Other examples of compositional heterogeneity include samples 1617M (66.4 weight percent $\mathrm{SiO}_{2}$ ) and $1618 \mathrm{M}$ (74.5 weight percent $\mathrm{SiO}_{2}$ ) that were collected from different blocks at the end of the shorter of two northern distal lobes dominated by dacite. Samples $1541 \mathrm{M}$
(66.8 weight percent $\mathrm{SiO}_{2}$ ) and $1542 \mathrm{M}$ (73.5 weight percent $\mathrm{SiO}_{2}$ ) were collected from opposite ends of the same $1-\mathrm{m}$ block.

All of the small domes are aphyric rhyolite except dome 7 , which consists of lower silica rhyolite that contains 1-2 percent phenocrysts. Four samples of dome 7 yield silica contents ranging from 72.3 to 73.4 weight percent (table 1), for an average of 73.0 weight percent. One sample from adjacent dome 8 overlaps this range at 73.3 weight percent, but the remaining 14 samples of the northern and southern domes range from 73.6 to 74.6 weight percent $\mathrm{SiO}_{2}$ and average 74.0 weight percent. The total volume of all the small domes taken together is very small, $<0.02 \mathrm{~km}^{3}$. 


\section{Inclusions}

Three types of inclusions were found in Glass Mountain lavas: quenched magmatic inclusions (QMI), cumulate, and a small number of pieces with fully crystallized plutonic textures ranging from granitic to gabbroic in composition (table 2). The spatial distribution of inclusion types is shown in figure 17. The QMI are the most common type (40 of 60 inclusion analyses listed in table 1). They are fine-grained, with $<5$ percent phenocrysts, and display features typical of chilled blobs of mafic magma that have been injected into a cooler host magma. As described by Bacon (1986), QMI are vesicular, have large vesicle spaces at the ends of the spheroidal blobs, and display crenulate convex-outward margins; radial fractures can typically be seen in the surrounding glassy lava host. Some fine-grained inclusions lack any phenocrysts but most include a scattering of larger crystals, commonly aggregates of $1-2 \mathrm{~mm}$ plagioclase together with $1 \mathrm{~mm}$ clinopyroxene and olivine, in a few cases accompanied by orthopyroxene and $\mathrm{Fe}-\mathrm{Ti}$ oxides, and rarely by hornblende. Abundant sub-millimeter crystals display rapid growth morphologies, for example, plagioclase showing hopper or skeletal shapes. Tiny pyroxene and plagioclase commonly form sprays of acicular crystals, in some cases together with hornblende. Small olivines are almost never present. Fe-Ti oxide grains and vesicular glass are ubiquitous. Photomicrographs of selected QMI samples are shown in figure 18.

The macroscopic features typical of the fine-grained chilled blobs of mafic magma (QMI) also characterize the cumulate inclusions, with the important exception that these latter inclusions exhibit 30-75 percent accumulated crystals. Nineteen such inclusions were analyzed and are listed in table 1. The accumulated crystals range in size from $1-5 \mathrm{~mm}$ and include phenocrysts of plagioclase, clinopyroxene, and olivine in all samples, orthopyroxene and Fe-Ti oxides in six samples, and hornblende in just three of the samples. The larger crystals are set in a glassy vesicular matrix exhibiting abundant tiny plagioclase and pyroxene crystals, Fe-Ti oxides, and in 11 cases, hornblende. The groundmass crystals display rapid growth morphologies, commonly occur in sprays of acicular crystals, and mimic the appearance of the fine-grained QMI inclusions. The abundance of groundmass glass and quench crystals like those of the fine-grained QMI indicate that the cumulate inclusions are co-magmatic. Photomicrographs of selected cumulate samples are shown in figure 19.

Inclusions range in size from microscopic crystal clots to nearly a meter across. Most are $15 \mathrm{~cm}$ or less in the longest dimension. QMI are common in the dacitic portions of the main Glass Mountain flow, where they may constitute 1 percent or more of the volume. They are present, but less common, in rhyolitic host lavas. Of 27 inclusions collected from the main flow, all are QMI with the single exception of one cumulate (1579M-a, table 1, fig. 17). One sample of included material (1543M-a, table 1) is characterized as neither QMI nor cumulate. It occurs as an aphyric rind on a partially melted granitic inclusion and is higher in $\mathrm{SiO}_{2}$ (62.8 weight percent) than the bulk of the QMI (54.5 to 58.8 weight percent $\mathrm{SiO}_{2}$ ). This inclusion and sample $1679 \mathrm{M}$ (with $\mathrm{SiO}_{2}$ of 60.7 weight percent) are similar to quenched andesitic inclusions found in Little Glass Mountain (Grove and Donnelly-Nolan, 1986).

The granitic inclusions found in Glass Mountain lavas are similar to those found in Little Glass Mountain and in the Medicine Lake Glass Flow. The latter flow also contains gabbroic inclusions similar to those found in Glass Mountain dome 7. Photomicrographs of a selected subset of the inclusions are shown in figure 20; chemical analyses are listed in table 2 .

The most diverse suites of inclusions were found at the distal ends of the Glass Mountain eruptive fissure. Inclusions have been found in the five northernmost domes (domes 6-10) and the southernmost dome, although no inclusions large enough for analysis were found in dome 6 , the smallest of the Glass Mountain domes. One small granitoid inclusion was seen in dome 6 . The six analyzed inclusions from the northernmost dome (dome 10) are all either plutonic or cumulate in texture, although thin sections of small, unanalyzed inclusions indicate that QMI are also present. Four QMI and four cumulate-textured inclusions were analyzed from the southernmost dome, where two granitic inclusions were also found. The 12 QMI in the small domes along the fissure range in composition from 54.2 to 60.7 weight percent $\mathrm{SiO}_{2}$, a somewhat greater compositional range than QMI in the main flow (54.5-58.8 weight percent $\mathrm{SiO}_{2}$ ), but the average silica content is nearly the same: 56.4 weight percent for the domes, 56.6 weight percent for the main flow. Table 1 includes 60 analyses of magmatic inclusions, which range in silica content from 50.8 weight percent to 62.2 weight percent, with the most mafic inclusions having cumulate textures. Inclusions were found only in lavas containing $<73.5$ weight percent $\mathrm{SiO}_{2}$. Available exposures of the initial tephra deposit along the length of the fissure do not appear to contain inclusions, but the deposits were not examined in detail.

The Glass Mountain eruption produced an unusually wide range of compositions from basalt to rhyolite. Welldefined arrays exist for most samples on many variation diagrams (fig. 21), although dacitic samples commonly show more scatter than the rhyolites and some inclusions plot off the trends. Compositions of all the erupted magmatic components at Glass Mountain form continuous arrays from basalt to rhyolite on major- and trace-element plots.

\section{Storage and Extrusion of Magma}

The Glass Mountain eruption was clearly complex, involving multiple compositions erupted along the length of the 5-km fissure. The fissure eruption was dike-fed near the surface, although the shape of the deeper magma reservoir is unknown. The distribution of cumulate and plutonic inclusions, which are nearly all found at the ends of the fissure, suggests that the ends of the dike may have sampled reservoir margins. Eichelberger (1975) proposed a model of the magma system in which dacitic magma was postulated to overlie 


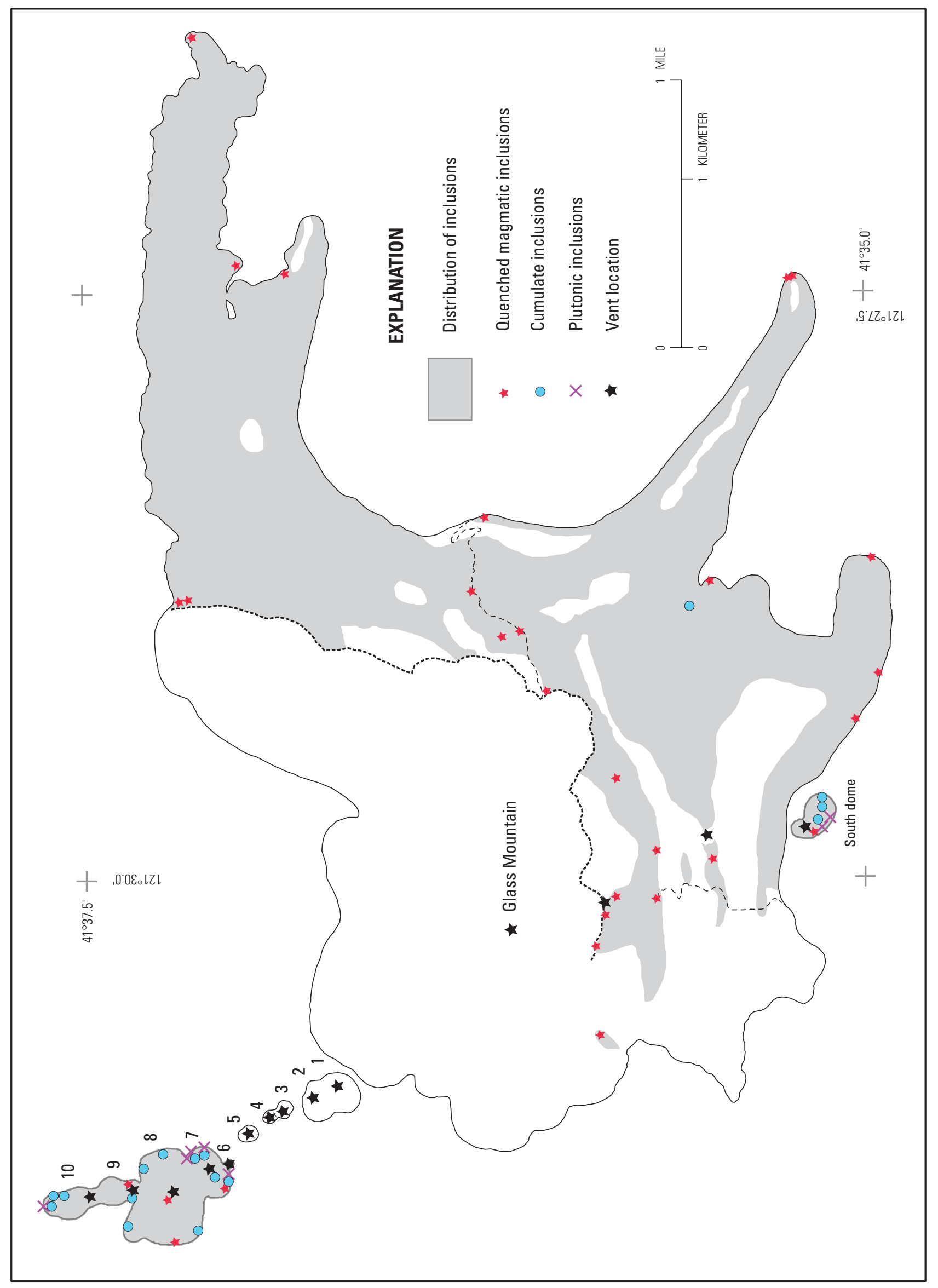

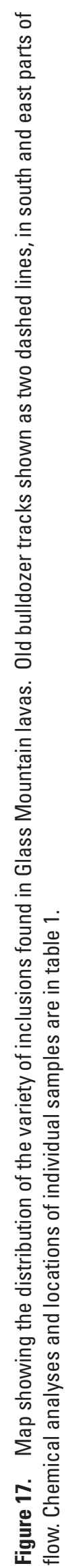






Figure 18. Photomicrographs of quenched magmatic inclusions in Glass Mountain lavas. Images on left taken in plane light; those on right are equivalent images under crossed-polarized light. $(A, B) \mathrm{ML}-4$ ( 54.2 weight percent $\left.\mathrm{SiO}_{2}\right)$ contains abundant elongate plagioclase together with clinopyroxene in part as sprays of elongate crystals in dark vesicular groundmass; $(C, D) 1140 \mathrm{M}-f\left(56.7\right.$ weight percent $\mathrm{SiO}_{2}$ ) has intergrown pyroxene and skeletal plagioclase in a vesicular matrix of brownish glass together with small brown needles of amphibole; $(E, F) 1715 \mathrm{M}$ (58.7 weight percent $\left.\mathrm{SiO}_{2}\right)$ shows small prisms of brown amphibole together with larger pyroxene and plagioclase, plus oxide grains in a vesicular, brownish glassy groundmass that contains tiny needles of plagioclase and pyroxene(?). All images are the same scale. Chemical analyses are in table 1. 


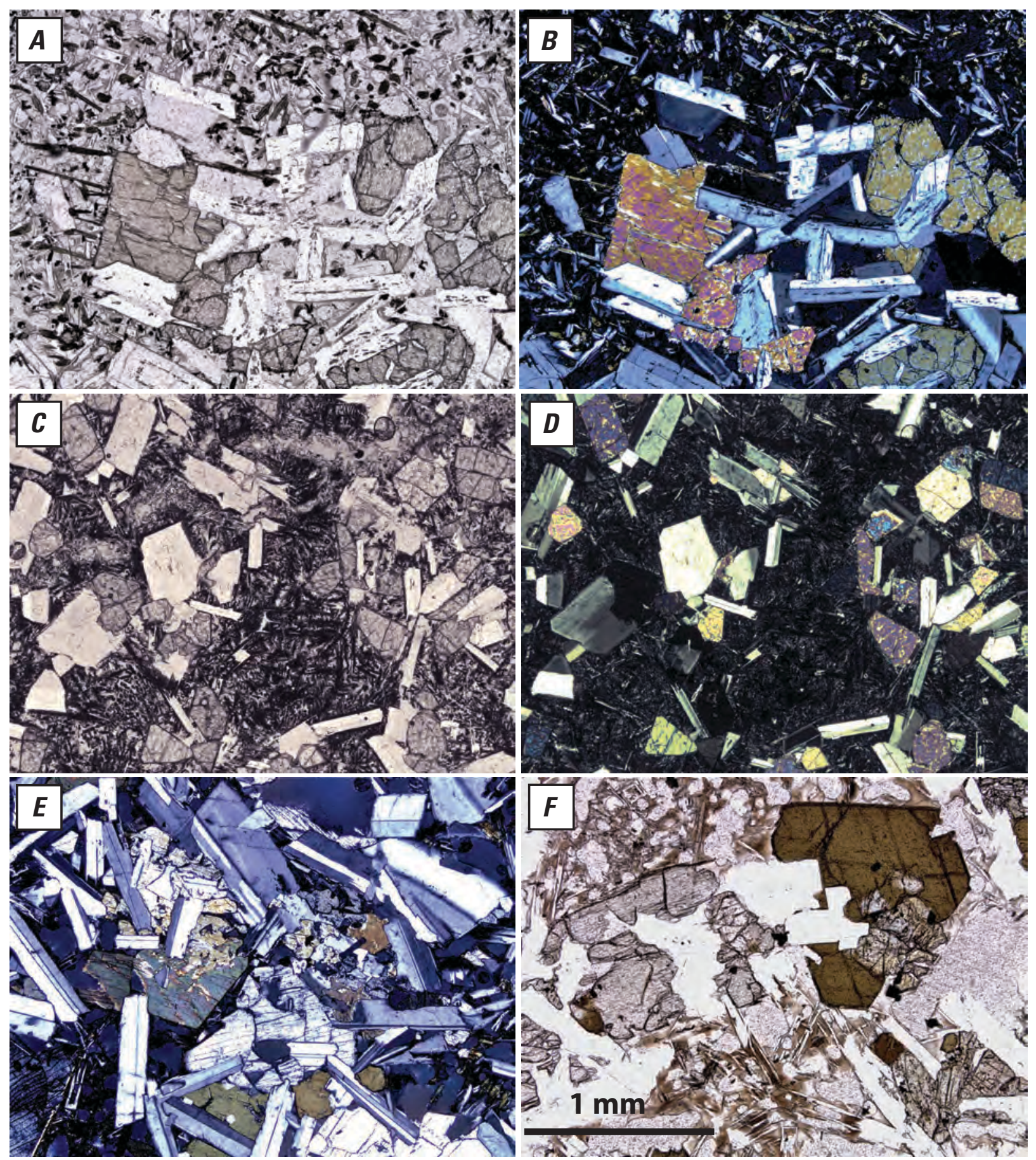

Figure 19. Photomicrographs of cumulate-textured inclusions in Glass Mountain lavas. Images on left of $A$ and $B, C$ and $D$ taken in plane light; those on right are equivalent images under crossed-polarized light. $(A, B) 1141 \mathrm{M}$ (52.1 weight percent $\mathrm{SiO}_{2}$ ) exhibits phenocrysts of olivine, clinopyroxene, and plagioclase in a fine-grained matrix with plagioclase, amphibole, and pyroxene needles, and oxide grains in vesicular glass; $(C, D) 1312 \mathrm{M}\left(53.0\right.$ weight percent $\left.\mathrm{SiO}_{2}\right)$ contains plagioclase, clinopyroxene, and olivine phenocrysts in fine-grained matrix of pyroxene needles studded with small opaque grains, small amphibole and plagioclase laths, and glass; $(E)$ cross-polarized light image of $1691 \mathrm{M}$ (54.9 weight percent $\left.\mathrm{SiO}_{2}\right)$ has intergrown plagioclase, brown amphibole, clinopyroxene, and orthopyroxene crystals with interstitial glass matrix containing plagioclase laths, oxide grains, and elongate skeletal amphibole; ( $F$ ) plane light image of 1139M-a (54.1 weight percent $\mathrm{SiO}_{2}$ ) displays a large crystal of brown amphibole and adjacent clinopyroxene and orthopyroxene in a glassy vesicular matrix containing small skeletal plagioclase, pyroxene needles, and oxide cubes. All images are the same scale. Chemical analyses are in table 1. 

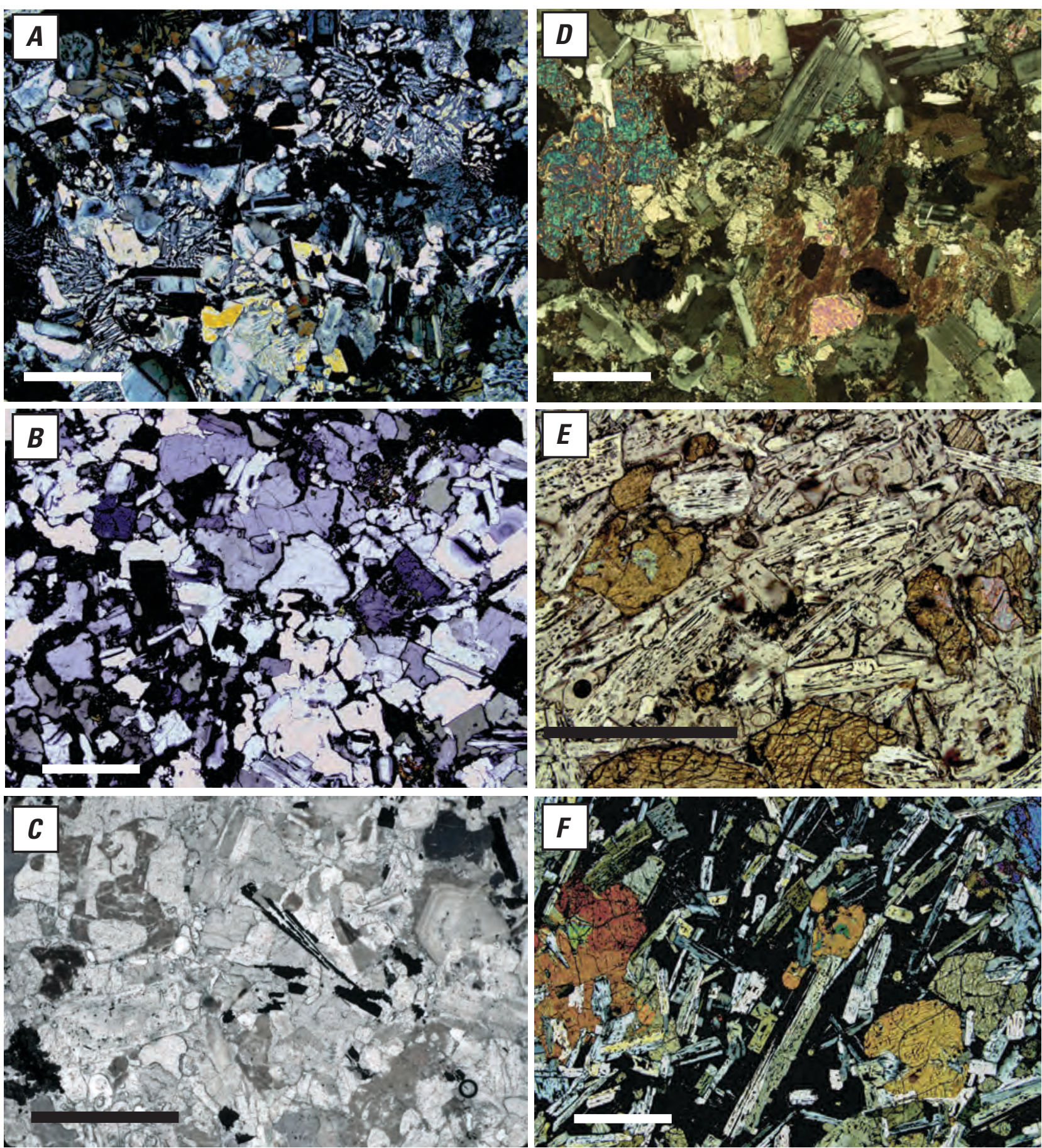

Figure 20. Photomicrographs of plutonic inclusions in late Holocene silicic lavas. Samples shown in images $A$, $B$, and $C$ on the left are granitic; samples $D, E$ and $F$ on the right are gabbroic. (A) Sample 2028M (73.7 weight percent $\mathrm{SiO}_{2}$ ) from the Medicine Lake Glass Flow, in crossed-polarized light view shows plagioclase, quartz, and oxidized biotite, in a matrix of graphic-textured intergrowth of quartz and potassium feldspar. (B) Sample 2029M (73.7 weight percent $\mathrm{SiO}_{2}$ ) from Little Glass Mountain flow shows partial melting in this crossed-polarized light view; note that a thin zone of melt surrounds crystals of feldspar, quartz, biotite, and small orthopyroxene and oxide grains. (C) Sample 663M-c (73.6 weight percent $\mathrm{SiO}_{2}$ ) from Little Glass Mountain; shows intergrown feldspar and quartz plus long needle of biotite near the center of the crossed-polarized light image. (D) Sample 1045M-a (50.0 weight percent $\mathrm{SiO}_{2}$ ) from Glass Mountain dome 7; the crossed-polarized light view shows intergrown plagioclase, pyroxene, olivine, biotite, and amphibole. $(E, F)$ Two views of sample 2027M from Medicine Lake Glass Flow ( 50.3 weight percent $\mathrm{SiO}_{2}$ ) which show intergrown plagioclase, two pyroxenes, and minor olivine together with small oxide grains and vesicular interstitial glass; $E$ is plane light image; $F$ is crossed-polarized light image. Scale bars are each $1 \mathrm{~mm}$ in length. Chemical analyses are in table 2. 

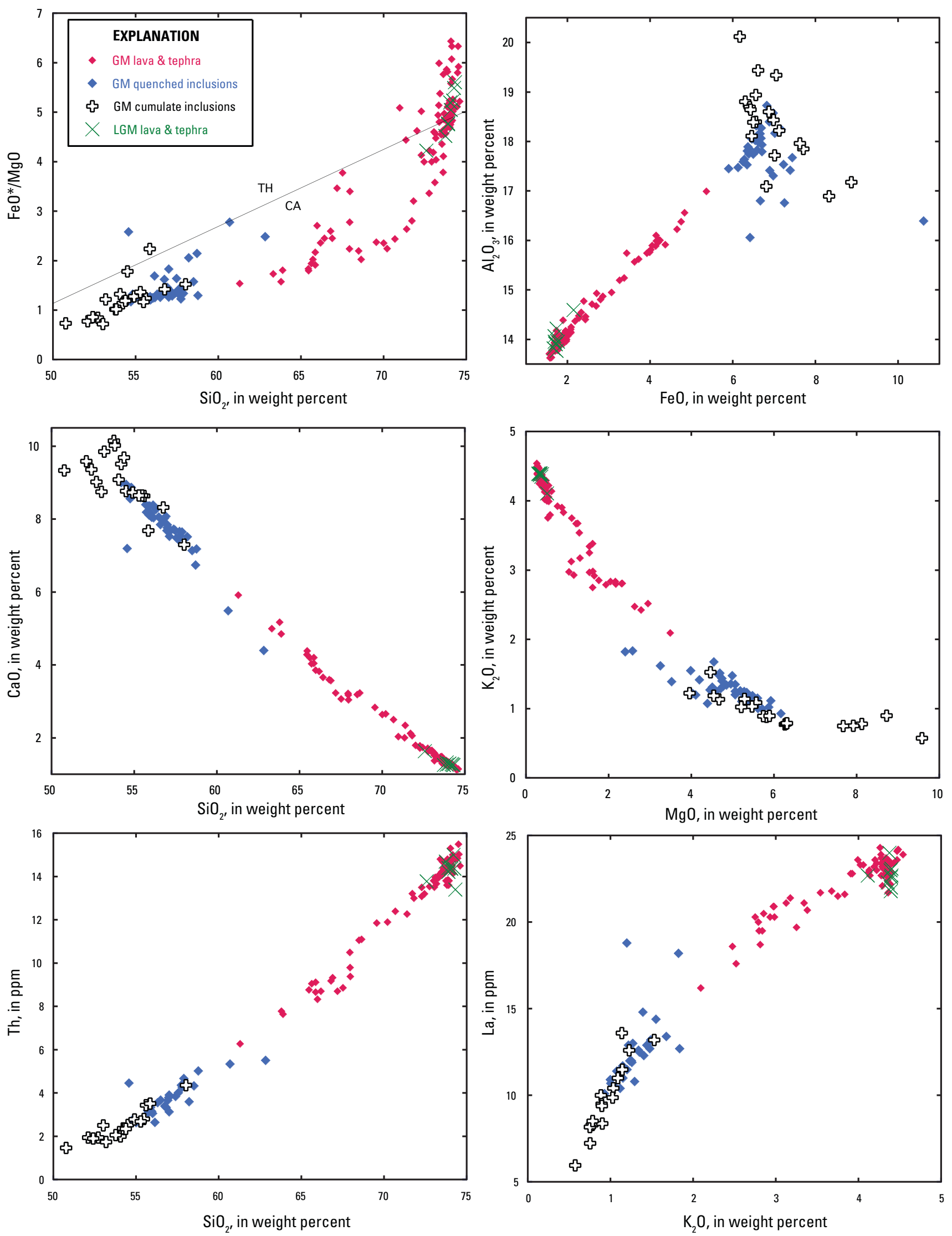

Figure 21. Plots showing the full range of compositions found in Glass Mountain (GM) including lavas, tephra, and inclusions). Little Glass Mountain (LGM) rhyolite samples are also shown for comparison with the Glass Mountain rhyolite. 

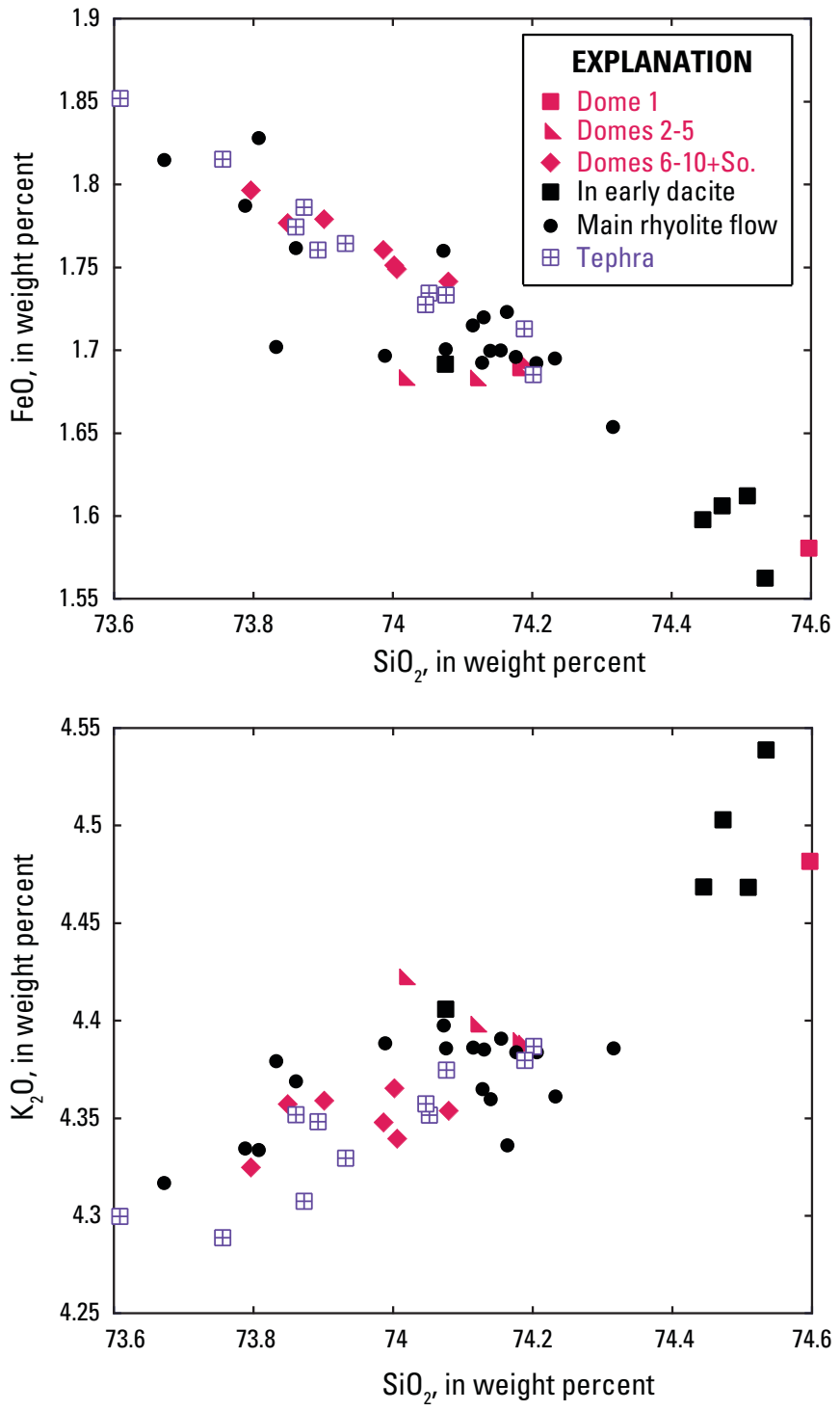

Figure 22. Plots show the highest-silica compositions of the Glass Mountain eruption. The 5 samples with the highest $\mathrm{SiO}_{2}$ (>74.4 weight percent) are from dome 1 and from 4 rhyolite "pods" within the early dacitic lobes of lava.

rhyolite magma prior to eruption. Eichelberger and others (2000) proposed a general model in which silicic magma can underlie and intrude overlying, more mafic magma; Glass Mountain is among the examples proposed. We reject this model because the early rhyolitic tephra came from the entire length of the fissure, clearly implying that rhyolite was the magma closest to the surface when the eruption began. We suggest instead that a layered Glass Mountain magma reservoir had aphyric rhyolite at the top, overlying mixed dacite that was itself a product of the mixing of rhyolite with intruded mafic magma. When mafic magma again intruded, setting off the eruption (as proposed by Eichelberger, 1981), some was incorporated as QMI. Following the initial rhyolitic explosive activity, underlying lower-viscosity dacitic magma was drawn up into the centrally located vents for the main flow. This may have occurred, in part, because the explosive emptying of the near-surface rhyolite magma allowed the hotter, less viscous dacite to rise more quickly than the higher viscosity rhyolite magma could be replenished laterally, resulting in a transition to effusive rather than explosive activity. Petrologic considerations also support the intrusion of underlying mafic magma into a shallower rhyolitic magma reservoir. Amphibole-bearing QMI record deeper crystallization depths $(\sim 6 \mathrm{~km})$ than andesitic QMI lacking amphibole $(\sim 3 \mathrm{~km})$, suggesting that fractional crystallization and crustal melting processes occurred over a range of depths that culminated in a shallow storage reservoir of aphyric rhyolite magma (Grove and others, 1997).

At times during the eruption, more than one magmatic composition entered the vent such that two of the early dacite lobes of the main flow dragged along large pod-like bodies, as much as $50 \mathrm{~m}$ in size, of aphyric rhyolite to the ends of the flow lobes. Compositional plots (fig. 22) of Glass Mountain lava and tephra samples that contain the highest 1 percent of $\mathrm{SiO}_{2}$ content (73.6 to 74.6 weight percent $\mathrm{SiO}_{2}$ ) indicate that neither the initial rhyolitic tephra nor the final Glass Mountain rhyolite lobe has the highest silica content. Rather, four samples of aphyric rhyolite caught up in the early dacite lava lobes as well as the single analysis of dome $1(1406 \mathrm{M}$, table 1$)$ have the highest analyzed $\mathrm{SiO}_{2}$ and $\mathrm{K}_{2} \mathrm{O}$ contents. This suggests that a small, localized cap of highest-silica viscous rhyolite existed locally at the center of the vent fissure. It is possible that some of this material may be present as individual pumice fragments in the initial tephra, but only a few single pumices were analyzed for this study. Intimately mingled rhyolite and dacite (for example, fig. 16) were probably also produced by juxtaposition in the vent. As the eruption progressed, either the QMI-bearing dacitic magma was depleted in the reservoir, or it was excluded from the vent conduit as the dominant upper rhyolitic magma forced its way back into the vent.

Recent rhyolite eruptions in Chile, at Chaiten (Castro and Dingwell, 2009; Pallister and others, 2013) and at Cordon Caulle (Tuffen and others, 2013), show that significant volumes of high-viscosity silicic lava can erupt in relatively short periods of time, from months to a year. The Glass Mountain eruption, larger and more complex than either of these, may have taken somewhat longer to erupt, but the new evidence from actual eruptions suggests that an elapsed time of only months to a few years would be adequate for $1 \mathrm{~km}^{3}$ of silicic magma to be emplaced. Thus, our failure to find a time signal using paleomagnetic sampling in Glass Mountain eruptive products is easily explained.

\section{Little Glass Mountain}

Erupted only half a century earlier than Glass Mountain, Little Glass Mountain (fig. 23) is located $\sim 16 \mathrm{~km}$ west of Glass Mountain on the opposite side of the caldera. This obsidian flow is the largest of 12 rhyolite extrusions, including 
the Crater Glass flows (figs. 24 and 25), that erupted $\sim 1,000$ years ago from a $10-\mathrm{km}$-long north-northeast-trending fissure. The eruption was preceded and accompanied by significant fracturing (fig. 26), creating an assemblage of north-northeast-trending open ground cracks (Fink and Pollard, 1983) shown in figure 27. Following an initial rhyolitic tephra eruption of $\sim 0.05 \mathrm{~km}^{3}$ (Fisher, 1964; Heiken, 1978), effusion of lava covered a total area of $6.3 \mathrm{~km}^{2}$. The total volume erupted was $\sim 0.4 \mathrm{~km}^{3}$. By contrast with Glass Mountain, Little Glass Mountain lavas and tephra are only rhyolitic and are limited in compositional range (fig. 21, table 1). However, none of the Little Glass Mountain lava is aphyric. Instead, noticeable phenocrysts are present throughout, typically $1-2$ percent of 1-2 mm plagioclase, orthopyroxene, and magnetite. A photomicrograph of the rhyolite lava is shown in figure $28 \mathrm{~A}$.

The eruption brought a cargo of QMI and cumulate inclusions to the surface. The inclusions were previously studied by Mertzman and Williams (1981), Grove and Donnelly-Nolan (1986), and Brophy and others (1996). In contrast with Glass Mountain, no preferential spatial distribution of inclusion types is displayed in Little Glass Mountain lavas (fig. 27). In addition to the magmatic inclusions, granitic fragments (figs. 20 and 29) were also brought to the surface. A few inclusions were also found near-vent in the initial tephra, but primarily as scattered constituents in the lava flows and domes that make up the bulk of the eruptive volume. Inclusions range in size from microscopic crystal clots to $70 \mathrm{~cm}$ in diameter (fig. 30). Inclusions large enough for analysis (typically $>7 \mathrm{~cm}$ ) are relatively rare. Several types of magmatic inclusions are present, including a variety of QMI ranging in silica content from 52.2 to 62.2 weight percent $\mathrm{SiO}_{2}$, and cumulate inclusions that span a compositional range from 51.8 to 57.3 weight percent $\mathrm{SiO}_{2}$, most of which are hornblende gabbro cumulates containing $\sim 53$ to 56 weight percent $\mathrm{SiO}_{2}$. Table 1 includes 9 analyses of the host rhyolite and 49 total analyses of magmatic inclusions, 27 of which are hornblende-bearing and show cumulate textures. Among the 22 other inclusions, 20 are QMI, of which 10 contain hornblende. Two other inclusions are possibly cumulate, one with and one without hornblende. Photomicrographs of a variety of inclusions are shown as figure $28 B-F$. Some analyses were previously published in Grove and Donnelly-Nolan (1986) and Brophy and others (1996).

Detailed petrographic descriptions of the inclusions can be found in both Grove and Donnelly-Nolan (1986) and Brophy and others (1996), so only a general description will be included here. Among the QMI, the basaltic andesite to lower-silica andesite inclusions are typically aphyric, but contain microphenocrysts of olivine, plagioclase, and clinopyroxene in a vesicular glassy groundmass. Andesitic inclusions with $>57$ weight percent $\mathrm{SiO}_{2}$ contain orthopyroxene, plagioclase, and Fe-Ti oxide phenocrysts \pm hornblende \pm clinopyroxene phenocrysts in a vesicular rhyolitic glass matrix. The QMI with the highest silica contents are aphyric and contain

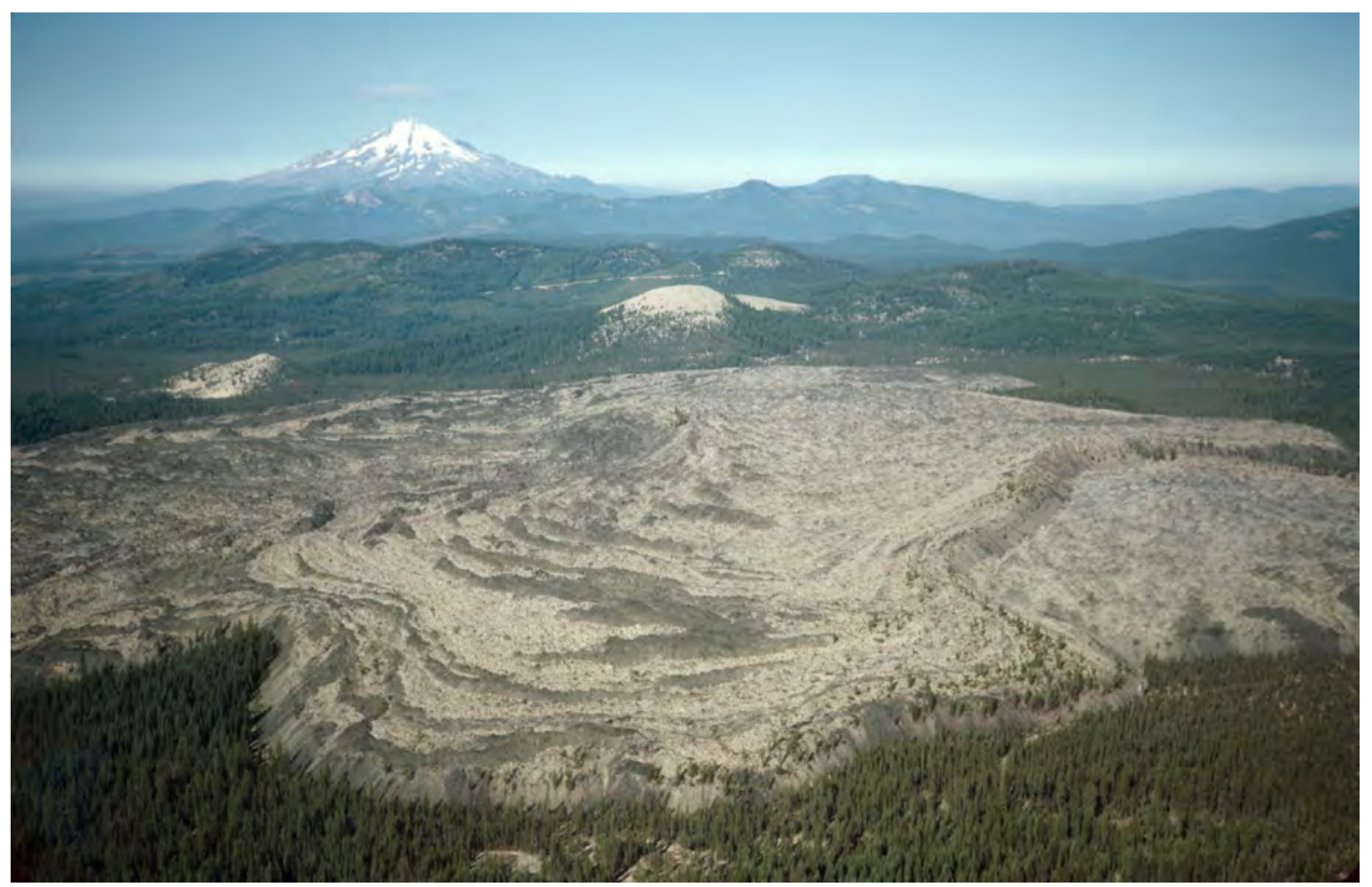

Figure 23. Aerial view of Little Glass Mountain, looking west, with snow-covered Mount Shasta on the horizon. Prominent white cone in center just beyond the Little Glass Mountain rhyolite flow is Pumice Stone Mountain, which is mantled by early tephra of the Little Glass Mountain eruption. On left, just beyond the rhyolite flow is late Holocene Paint Pot Crater, also mantled by younger tephra of Little Glass Mountain. 


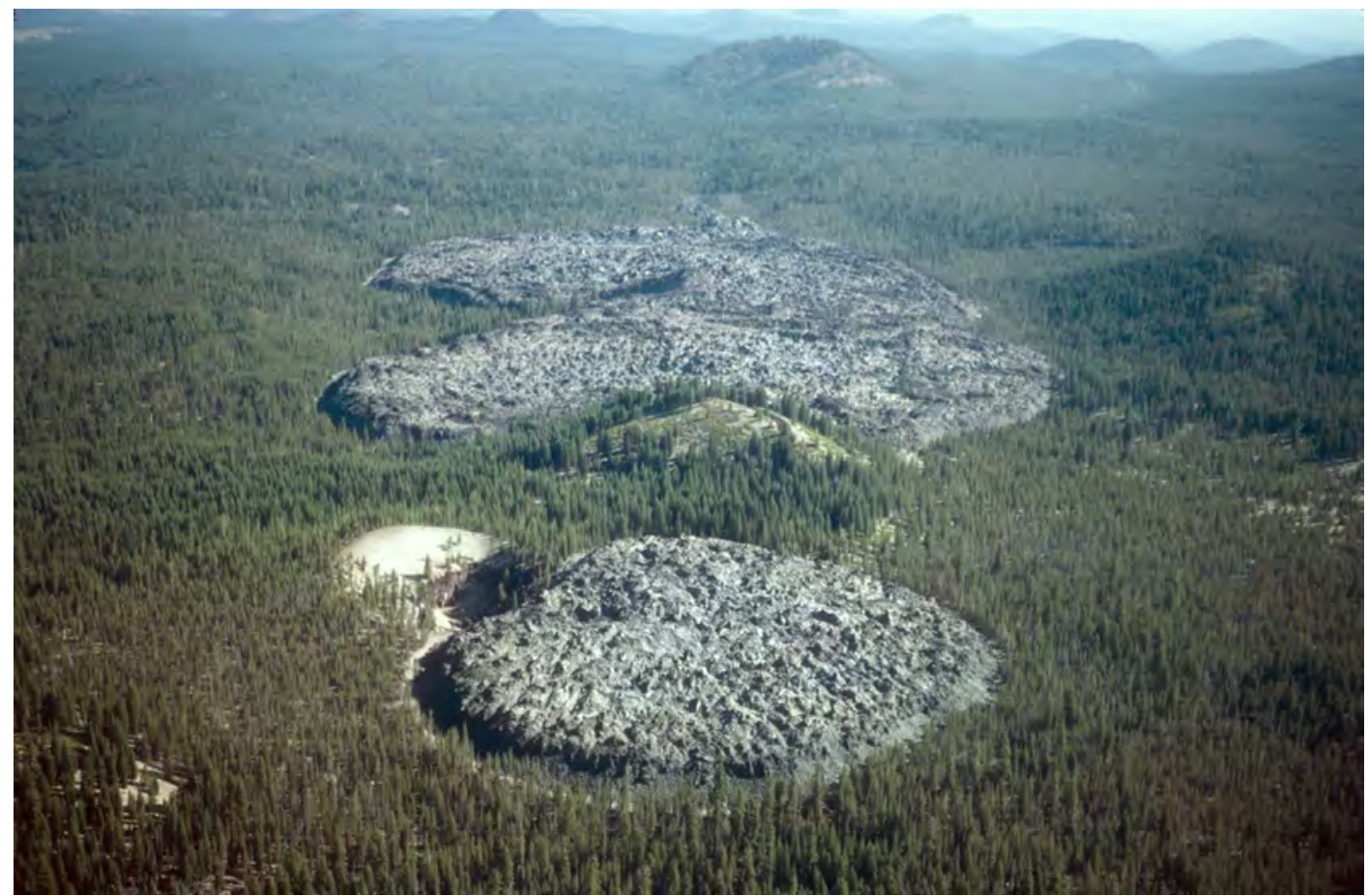

Figure 24. Aerial view looking northeast across the rocky and unvegetated Crater Glass flows. The small explosion crater to the left of the nearest flow gives this part of the Little Glass Mountain rhyolite fissure its name.

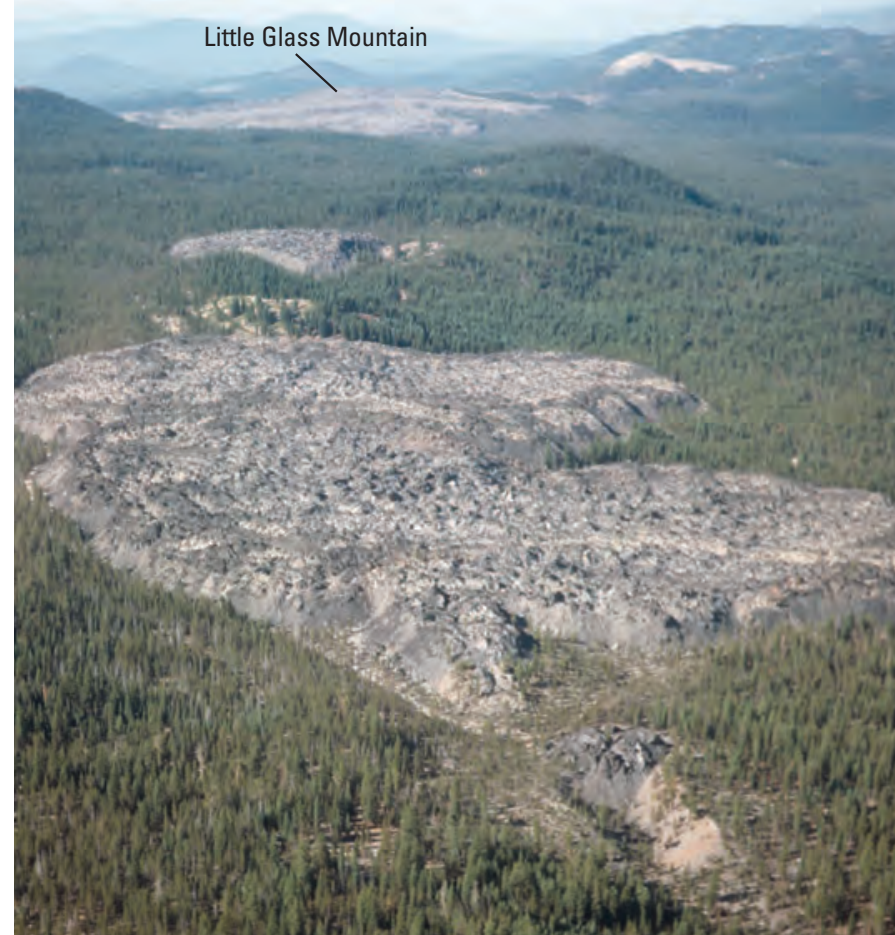

Figure 25. Aerial view looking southwest over the Crater Glass flows toward Little Glass Mountain along the entire length of the $\sim 1,000$-yr-old rhyolite eruptive fissure.

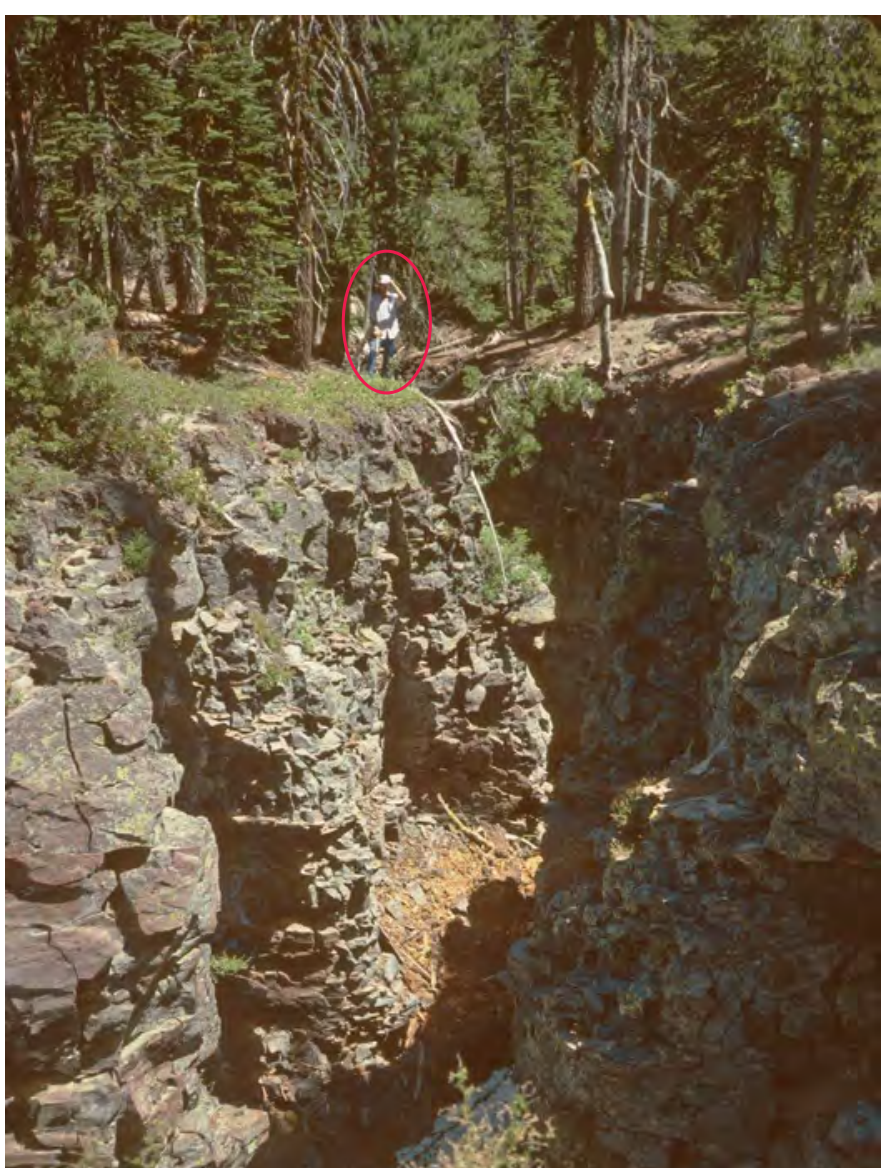

Figure 26. The Little Glass Mountain eruption was accompanied by the opening of cracks along, and parallel to, the vent fissure (Fink and Pollard, 1983). The walls of the crack fit back together in east-west direction. Red ellipse encompasses person for scale. This photograph was previously published as figure 7 in DonnellyNolan and others (2007). 


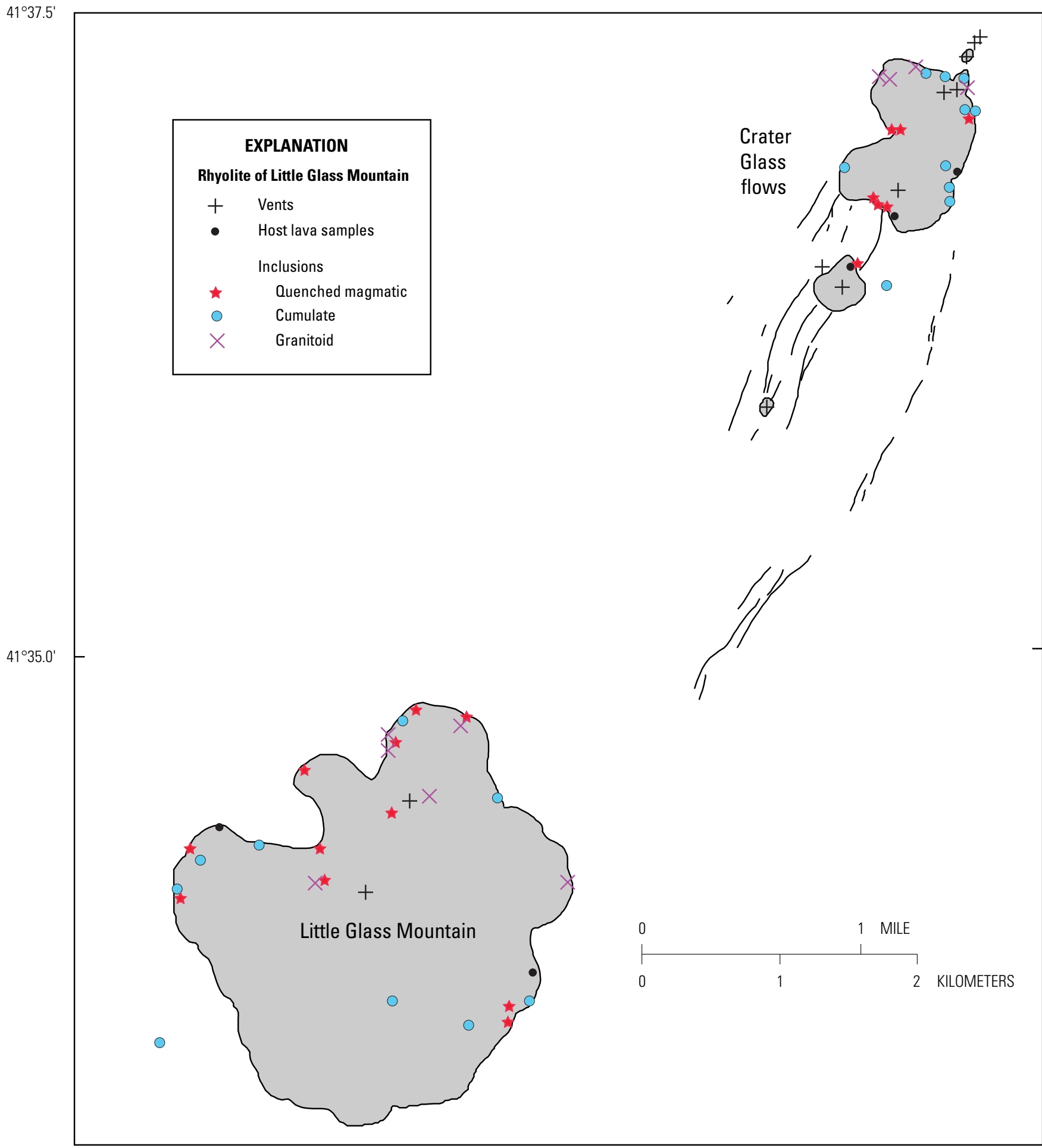

Figure 27. Map showing lavas erupted from the Little Glass Mountain fissure (gray) and vents (black crosses). Also shown are the locations where samples of lava and the different types of inclusions were collected. Two of the cumulate inclusions were collected in the tephra deposits and plot away from the lava flows. Open ground cracks shown as black lines are from Donnelly-Nolan (2010). More detailed mapping of the cracks is shown in Fink and Pollard (1983). 

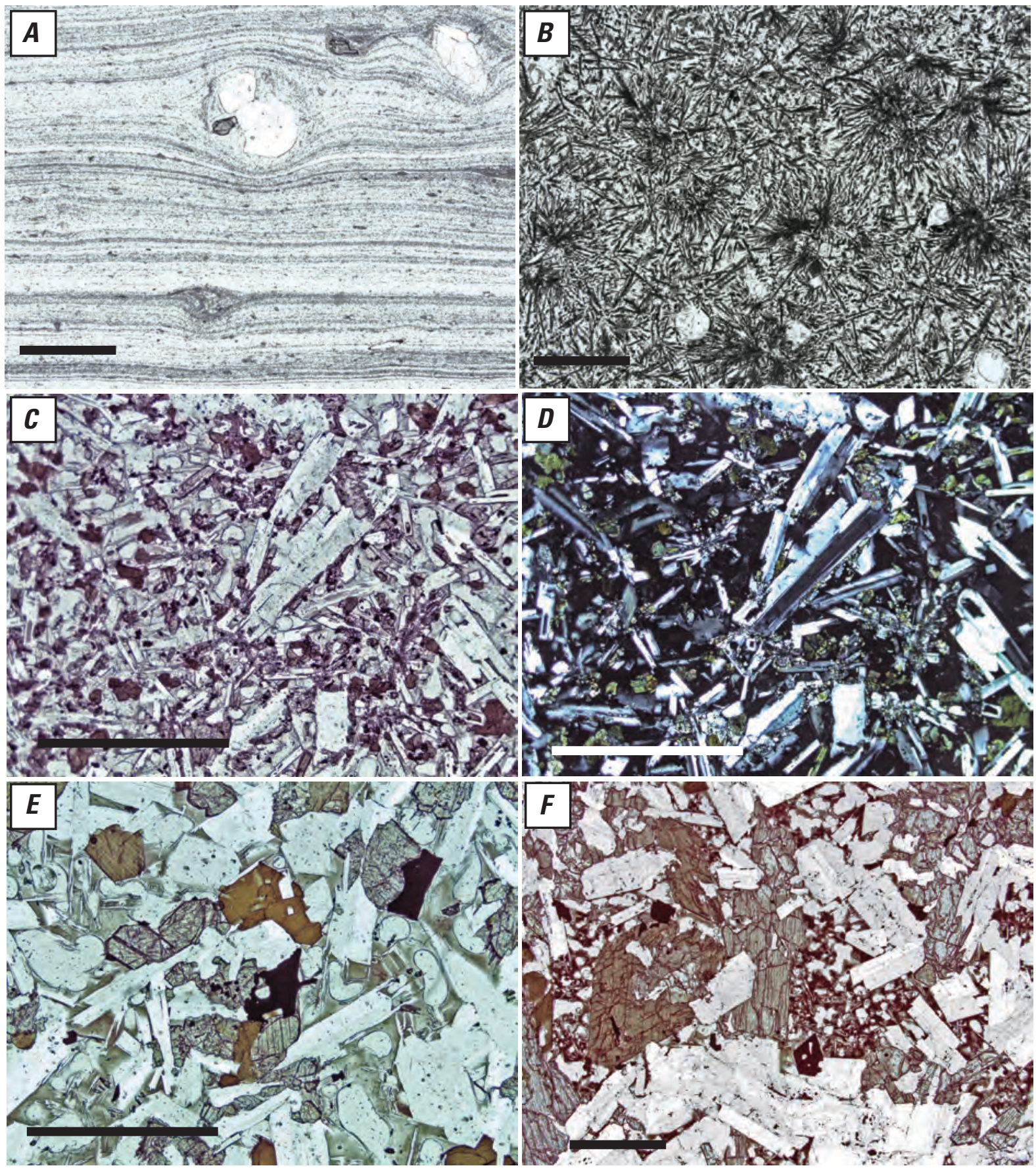

Figure 28. Photomicrographs of the Little Glass Mountain host lava and a variety of inclusions. $(A)$ The host rhyolite lava (sample 35M, 73.7 weight percent $\mathrm{SiO}_{2}$ ) showing flow foliation defined by aligned microlites wrapping crystals of plagioclase and orthopyroxene; plane light. $(B)$ Sample 1235M (a quenched magmatic inclusion containing 59.8 weight percent $\mathrm{SiO}_{2}$ ), in plane light shows rosettes dominated by dark hornblende needles; needles of pyroxene and plagioclase are less visible; round white areas are vesicles surrounded by clear glass. $(C, D)$ Plane and crossed-polarized light views of sample 1025M-i (a quenched magmatic inclusion containing 55 weight percent $\mathrm{SiO}_{2}$ ) show larger euhedral plagioclase crystals set among smaller plagioclase, pyroxene, hornblende, and Fe-Ti oxides; some of the smaller crystals are arrayed in rosettes best seen in (D); glass and vesicles are present in interstices. (E) Plane light view of sample 1746M, a hornblende gabbro cumulate inclusion containing 55.3 weight percent $\mathrm{SiO}_{2^{\prime}}$ that shows brown hornblende together with plagioclase, two pyroxenes, and $\mathrm{Fe}$-Ti oxide grains in a vesicular glassy groundmass; see also figure 30 for a photograph of the inclusion as discovered in the field; other hornblende gabbro inclusions are depicted and described in Grove and Donnelly-Nolan (1986). (F) Plane light view of sample 1025M-f, a cumulate hornblende gabbro inclusion with 53.6 weight percent $\mathrm{SiO}_{2}$, that displays the same mineralogy as $1746 \mathrm{M}$ except that it is coarser and olivine is also present (high-relief irregularly fractured mineral in upper right of view). Scale bars are each $1 \mathrm{~mm}$ in length. Chemical analyses are in table 1. 


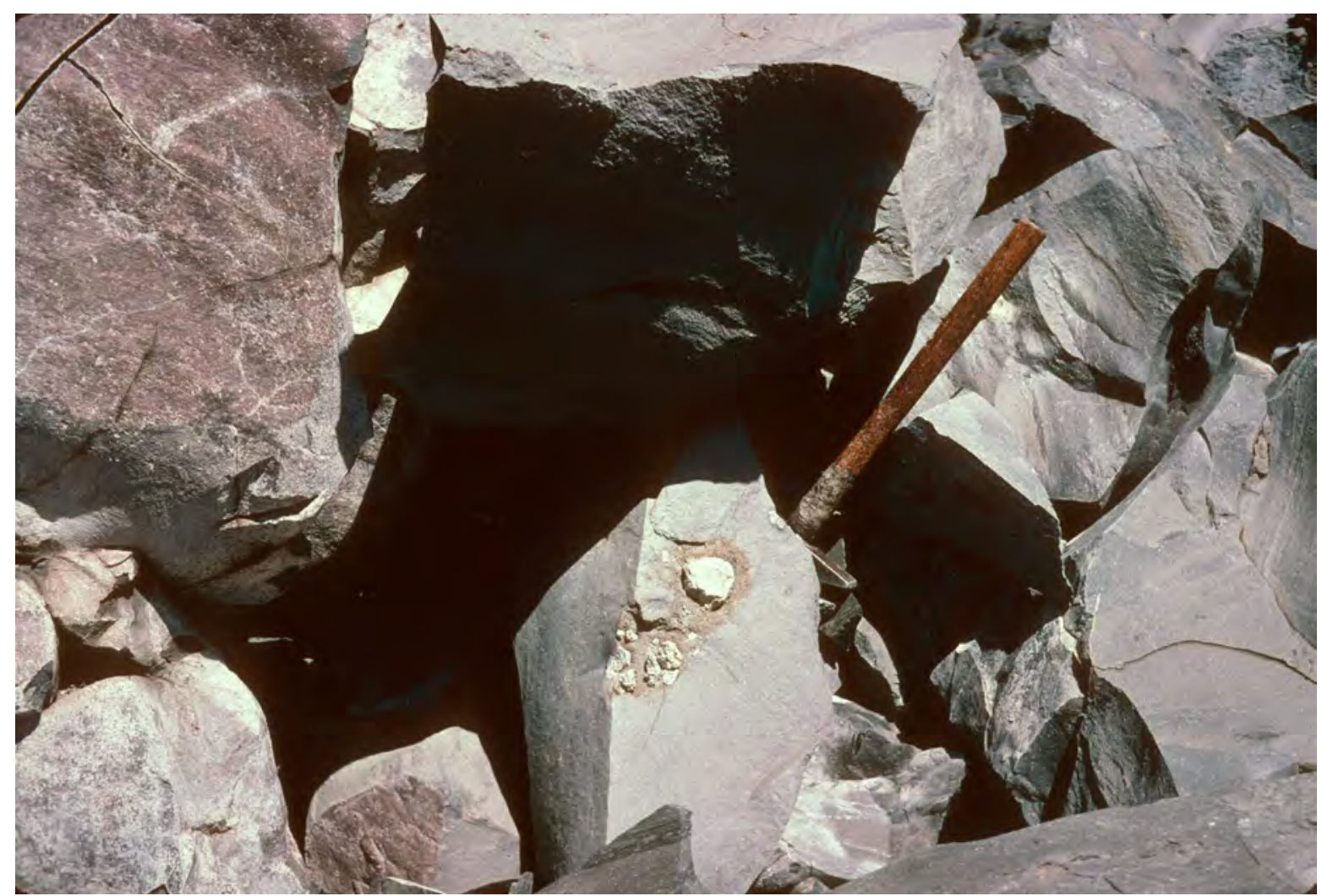

Figure 29. Photograph showing typical occurrence of granitic inclusions found in Little Glass Mountain lava. Hammer handle is $47 \mathrm{~cm}$ long.

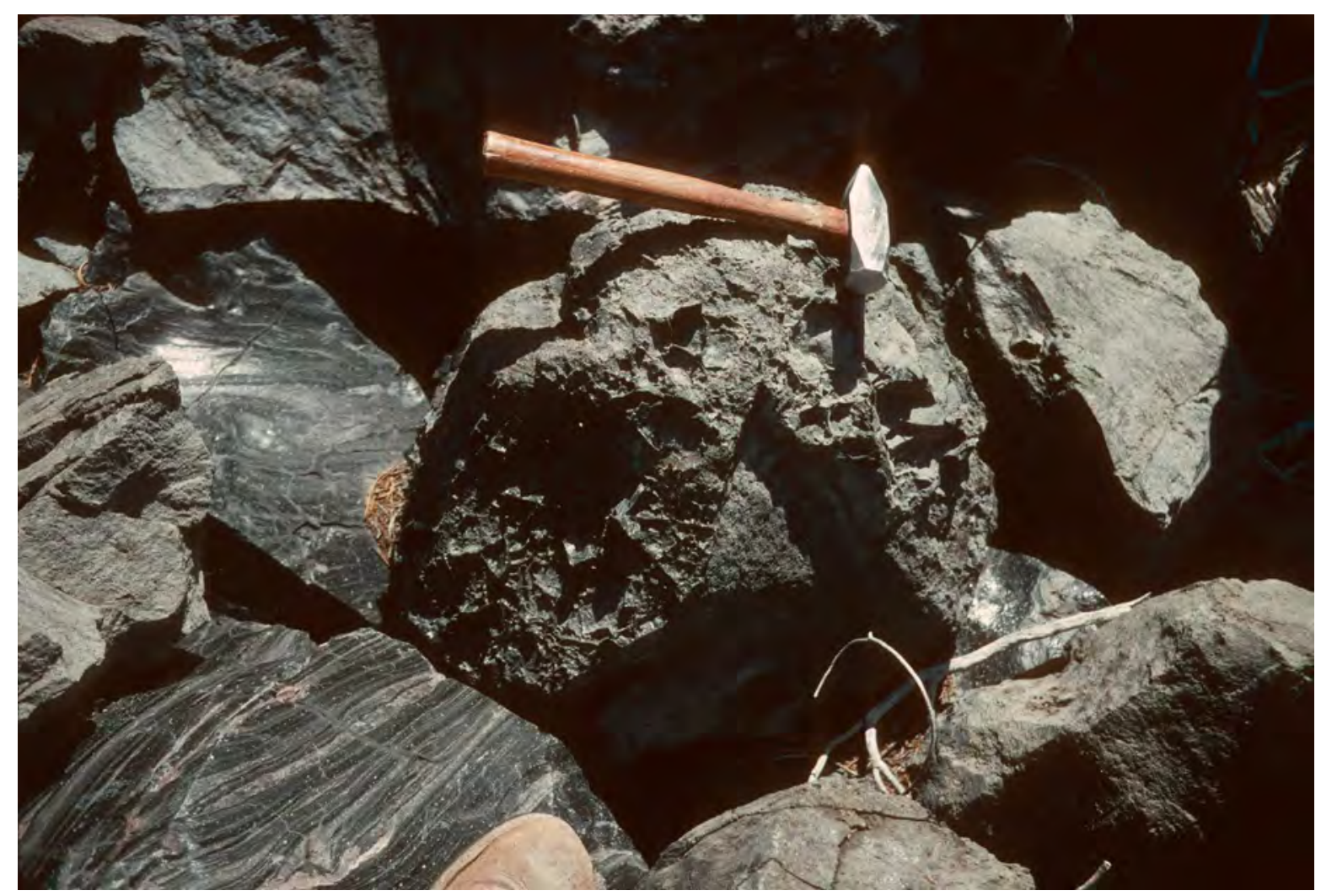

Figure 30. Largest sampled magmatic cumulate inclusion (1746M) in Little Glass Mountain sits among blocks of rhyolite at the edge of the flow. Hammer handle is $33 \mathrm{~cm}$ long. See table 1 for chemical analysis and location information, figure 28 for photomicrographs. 



Figure 31. Plots comparing mafic magmatic inclusion suites in the Glass Mountain (GM, red symbols) and Little Glass Mountain (LGM, blue symbols) lavas. Solid symbols are cumulate inclusions; open symbols represent quenched magmatic inclusions.

quench groundmass amphibole in a vesicular glass matrix. The cumulate inclusions typically contain plagioclase, clinopyroxene, olivine, orthopyroxene, hornblende, and Fe-Ti oxides that form a network of crystals set in a vesicular matrix of rhyolite glass.

Silica variation diagrams that compare compositions of QMI and cumulate inclusions in Little Glass Mountain and Glass Mountain are shown in figure 31. The inclusions brought to the surface in the two eruptions overlap in composition. Only a few of the Glass Mountain inclusions contain hornblende and closely resemble the hornblende gabbro cumulates found at Little Glass Mountain. The Little Glass Mountain QMI show a broader range of compositions.

\section{Basaltic Andesite of Paint Pot Crater}

The Paint Pot Crater eruption produced the youngest mafic lava flow at MLV. This small flow, known locally as "tilted rocks" for its rugged surface, erupted from a cinder cone and spatter vents located $\sim 5 \mathrm{~km}$ southwest of the caldera rim (fig. 4A). The eruption took place on the same northeast-trending alignment as the subsequent Little Glass Mountain rhyolite. The unit covers $\sim 2.7 \mathrm{~km}^{2}$ and has a volume of $\sim 0.04 \mathrm{~km}^{3}$. Its name is derived from the multi-colored red and black cinder cone, which is heavily mantled by white pumice (figs. 6 and 32) from the nearby Little Glass Mountain eruption. The Paint Pot Crater flow was not directly dated, but its age is closely 


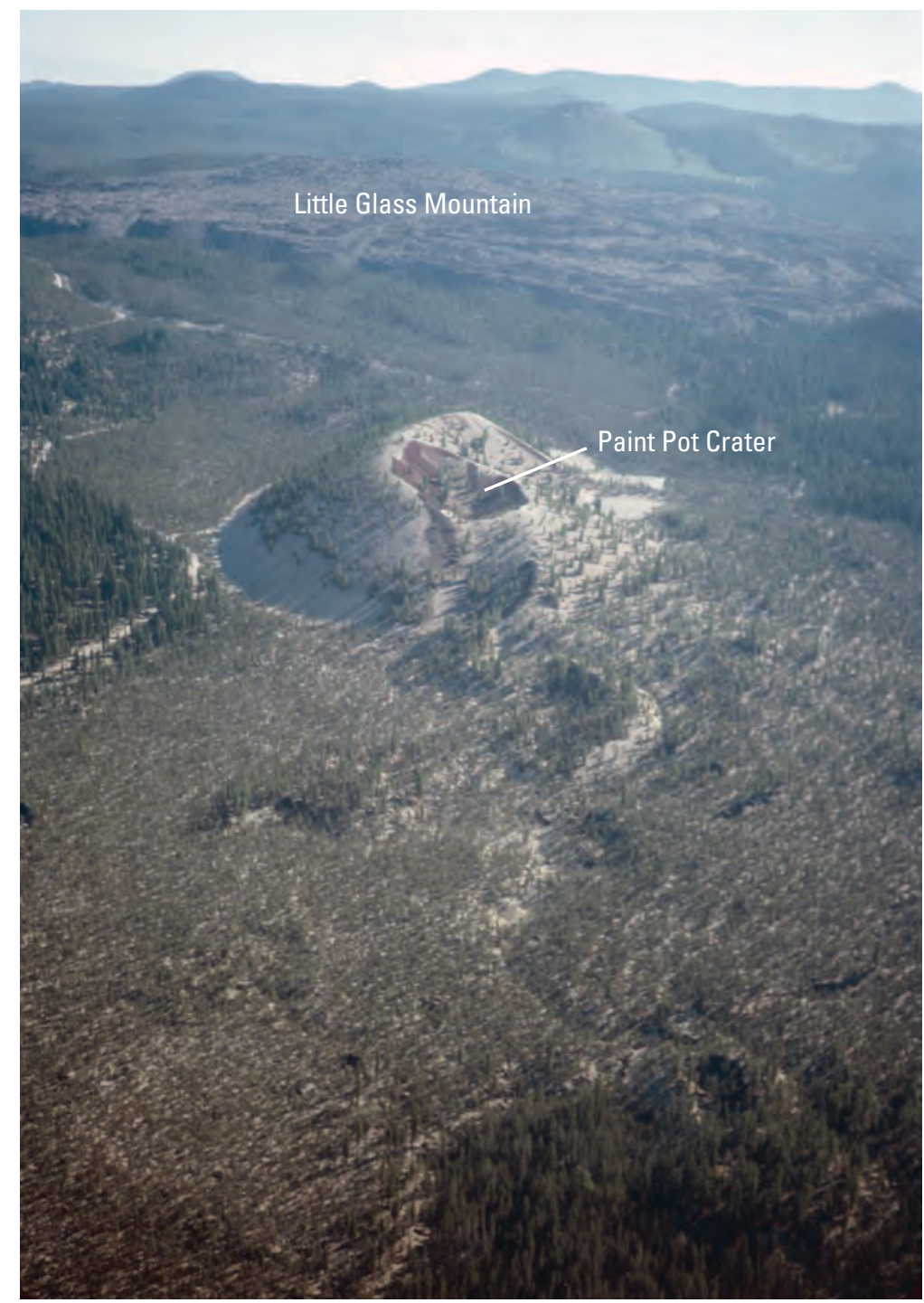

Figure 32. Aerial view looking northeast across the late Holocene Paint Pot Crater flow and cone, which displays a mantle of white pumice from the slightly younger (by a few decades) Little Glass Mountain eruption. The Little Glass Mountain rhyolite flow fills the middle ground just above and beyond Paint Pot Crater, with the rim of Medicine Lake caldera on the horizon.

constrained because its early tephra is enclosed between the underlying Callahan Flow tephra and the overlying Little Glass Mountain tephra (Donnelly-Nolan and others, 1990). The age is further constrained to $\sim 1,170$ years ago by the nearly identical orientation of its paleomagnetic direction with that of the radiocarbon-dated Callahan Flow (Nathenson and others, 2007).

Kinzler and others (2000) found no evidence of significant compositional zonation. Four chemical analyses of the lava ranging from 52.9 to 53.2 weight percent $\mathrm{SiO}_{2}$ are presented in table 1. Fine-grained basaltic crystal clots from $<1 \mathrm{~mm}$ to $\mathrm{cm}$-sized are present in the lava flow although none were large enough for chemical analysis. A few granitoid inclusions were also found (table 2). The flow contains noticeable 2-mm-wide olivine phenocrysts, among a total of approximately 5 percent of $1-2 \mathrm{~mm}$ plagioclase and olivine phenocrysts, with plagioclase more abundant than olivine. A photomicrograph of the lava is shown in figure $33 \mathrm{~A}$.

The Paint Pot Crater flow, the youngest mafic lava flow at Medicine Lake volcano, represents a wet calcalkaline basalt with geochemical characteristics typical of arc basalts. However, it is not the most recent mafic magma to be erupted because the younger Little Glass Mountain and Glass Mountain eruptions brought up numerous quenched magmatic inclusions (QMI) of calcalkaline basaltic andesite and andesite.

\section{Callahan Flow}

The andesite-to-basalt compositionally zoned Callahan Flow (Kinzler and others, 2000) erupted on the north flank of MLV $\sim 1,180$ years ago. The primary vent is a large cinder cone named Cinder Butte (fig. 34), but lava also escaped to 

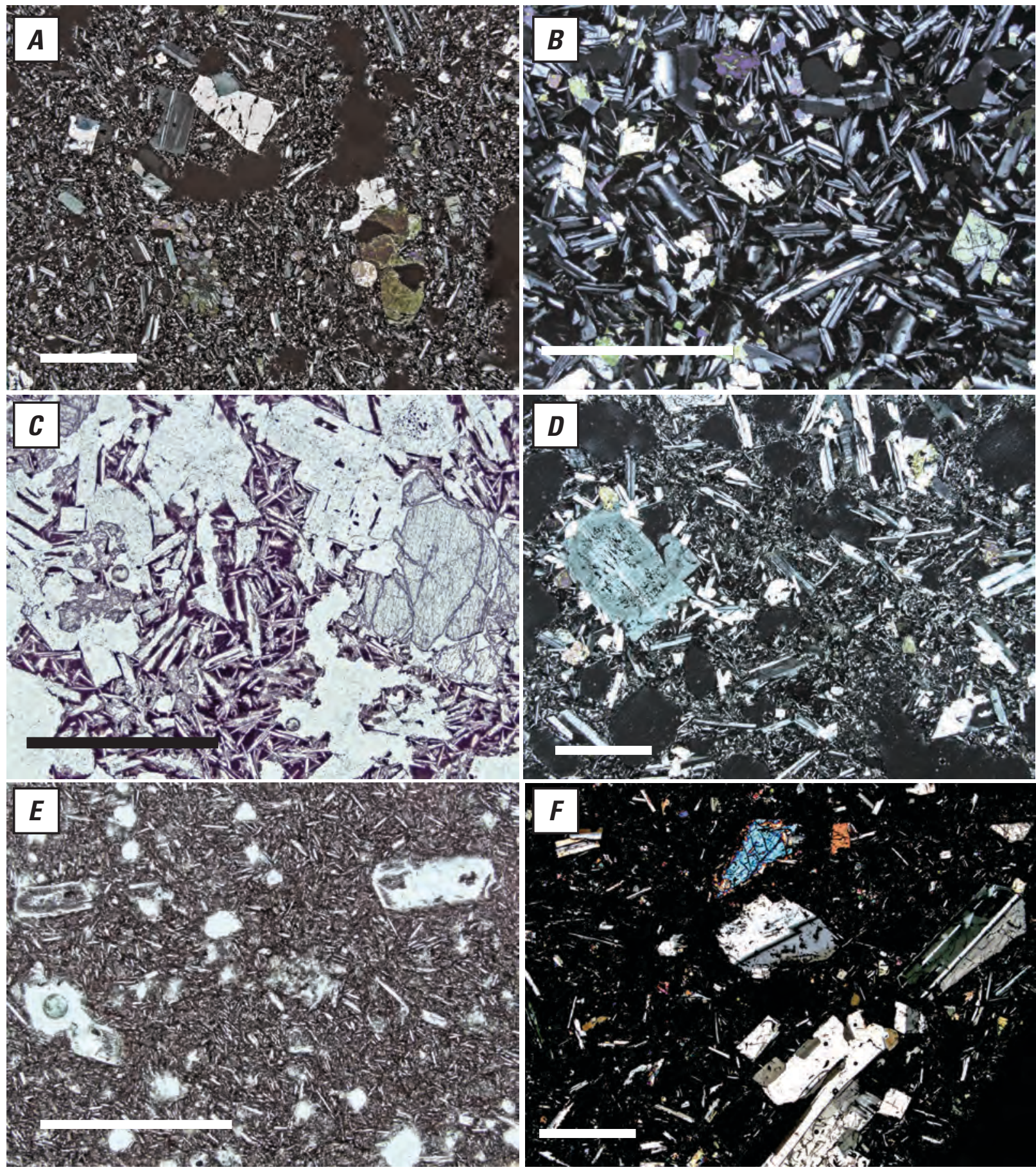

Figure 33. Photomicrographs of the late Holocene mafic host lavas. $(A)$ The basaltic andesite of Paint Pot Crater flow (sample 1662M, 53.2 weight percent $\mathrm{SiO}_{2}$ ), in crossed-polarized light, shows phenocrysts of olivine and plagioclase in a glassy to microcrystalline groundmass containing smaller plagioclase and olivine. $(B-D)$ Three samples of the Callahan Flow showing lava samples with a range of silica contents and a variety of plagioclase-dominated textures: $(B)$ sample $146 \mathrm{M}$ (crossed-polarized light) contains 57.6 weight percent $\mathrm{SiO}_{2} ;(C)$ sample $1103 \mathrm{M}$ (plane light) has 54.7 weight percent $\mathrm{SiO}_{2}$; and $(D)$ sample $1399 \mathrm{M}$ (crossed-polarized light) has 51.8 weight percent $\mathrm{SiO}_{2}$. (E) A plane-light view of sample $695 \mathrm{M}$, the andesite of the Burnt Lava Flow ( 57.5 weight percent $\mathrm{SiO}_{2}$ ), shows a few larger microphenocrysts of plagioclase in a felted matrix dominated by small plagioclase. $(F)$ crossed-polarized light image of sample $1675 \mathrm{M}\left(50.3\right.$ weight percent $\left.\mathrm{SiO}_{2}\right)$ from the Black Craters flow of the basalt of Black Crater and Ross Chimneys; the unit is typically porphyritic with as much as 25 percent of plagioclase and olivine phenocrysts. Scale bars are each $1 \mathrm{~mm}$ in length. Chemical analyses are in table 1. 


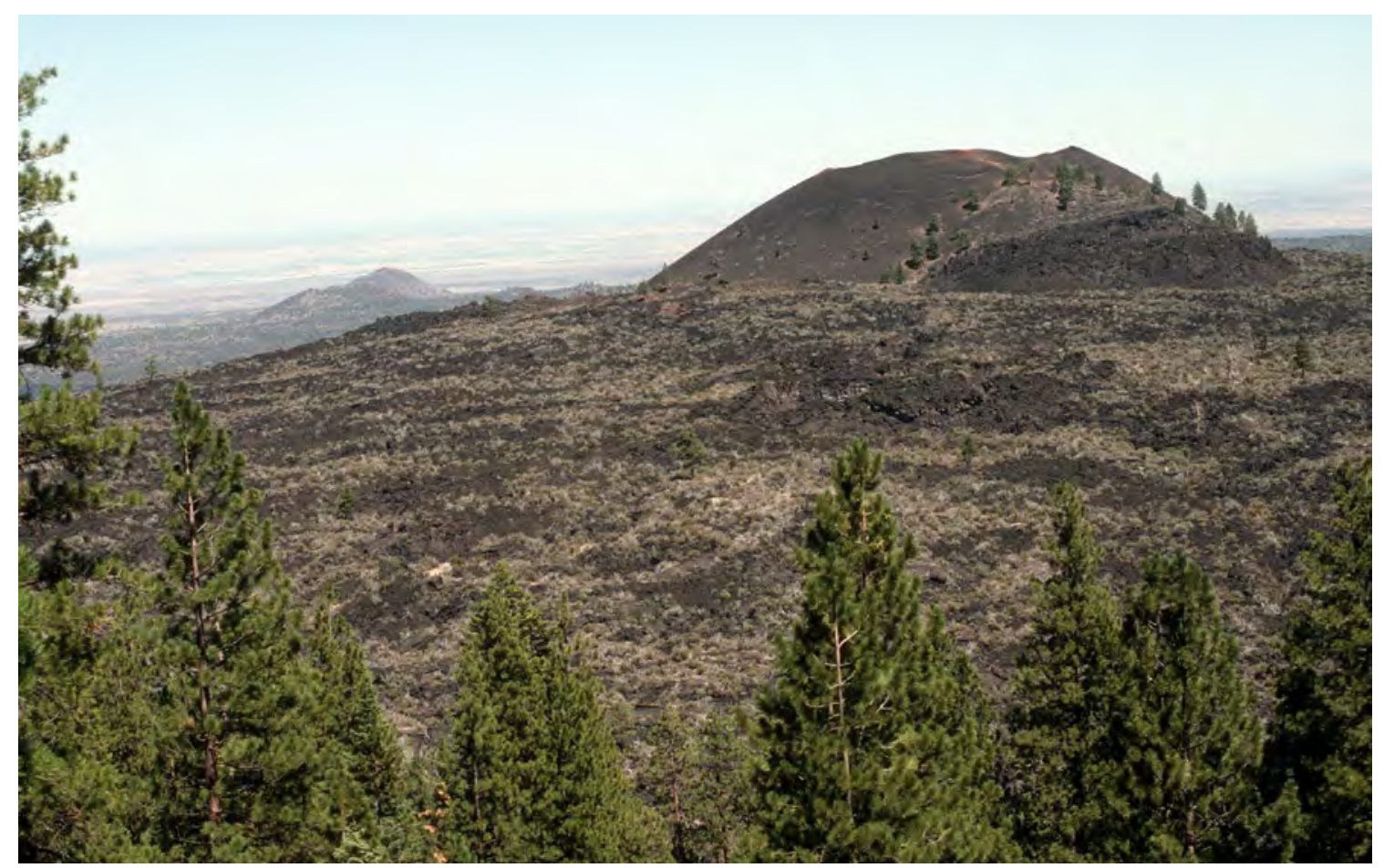

Figure 34. View northeast across the southern Callahan Flow and its main vent, Cinder Butte. Cone on left in middle distance is Schonchin Butte in Lava Beds National Monument.

the surface by way of adjacent north- and northwest-trending spatter vents. The flow covers an area of $23.7 \mathrm{~km}^{2}$, part of which lies within Lava Beds National Monument (fig. 3). The estimated volume of the flow is $0.33 \mathrm{~km}^{3}$. Silica content ranges from 51.8 percent to 58.0 percent (table 1), with the first-erupted andesite making up 50 percent of the volume, whereas the last-erupted basalt amounts to just 1 percent. This mostly treeless, dominantly 'a'ā lava flow was subdivided and mapped in five groups using petrographic and compositional criteria. A map showing the aerial distribution of the five different composition groups is shown as figure 1 in Kinzler and others (2000). Their figure 3 is a plot of log volume versus $\mathrm{MgO}$ content for the five compositional groups showing a nearly linear trend, indicating that both volume and silica content decreased as the eruption proceeded. Heights of flow fronts also decreased as silica content and viscosity decreased.

The eruption also produced tephra, some of which was found to the southwest underlying tephra from the Paint Pot Crater eruption (Donnelly-Nolan and others, 1990). Additional tephra was deposited on top of early flow lobes, indicating that explosive activity persisted during the eruption (Kinzler and others, 2000).

Photomicrographs of Callahan Flow lavas are shown in figure $33 B-D$. The early andesite facies is noticeably phyric and has $2-5$ percent of $1-3 \mathrm{~mm}$ plagioclase and $<1$ percent of $1 \mathrm{~mm}$ orthopyroxene, along with rare $1 \mathrm{~mm}$ olivine and a glassy interstitial groundmass. The most mafic rocks are nearly aphyric, with rare $1-3 \mathrm{~mm}$ plagioclase set in a crystalline, sugary groundmass. Compositional variations in the Callahan lavas resulted from the combination of fractional crystallization, crustal assimilation, and magma mixing prior to eruption. The mineral assemblages preserve evidence of these processes in populations of phenocrysts of widely varying composition (Kinzler and others, 2000).

No quenched magmatic inclusions were found in the flow although one cumulate inclusion was collected (Kinzler and others, 2000). Numerous melted silicic inclusions present in the Cinder Butte vent cone match a nearby older rhyolite flow in composition and petrography. No granitoid fragments were found.

\section{Hoffman Flows}

The earliest of the three late Holocene rhyolite eruptions at Medicine Lake volcano, the informally named Hoffman flows erupted $\sim 1,230$ years ago from a north-northwest-trending 2-km-long fissure tangential to the northeast caldera rim and $1 \mathrm{~km}$ west of the parallel Glass Mountain fissure (fig. 35). An early tephra deposit was exposed under the Glass Mountain tephra by quarrying adjacent to the north side of the Glass Mountain flow. Two separate areas of lava flow were produced from multiple vents (fig. $4 A, B$ ). The southern lobes flowed west into the caldera and east an unknown distance where they underlie the younger rhyolite of Glass Mountain. An estimate of the original areal extent of the unit is $\sim 8 \mathrm{~km}^{2}$; the estimated volume is $\sim 0.2 \mathrm{~km}^{3}$. Seven chemical analyses indicate a range of compositions with two analyses at 68.4 weight percent $\mathrm{SiO}_{2}$ and the other five between 71.3 and 72.4 weight percent. Two chemical analyses were presented in Grove and DonnellyNolan (1986); these, plus additional data are included in table 
1. No attempt was made to map out areas of lower-silica and higher-silica lava in the flows because only the westernmost intracaldera part of the southern flow area is sufficiently exposed. Closer to Glass Mountain, tephra from that eruption mantles the Hoffman flows and a thick tree cover is present, limiting exposures.

The Hoffman flows contain ubiquitous QMI ranging in size from microscopic to $30 \mathrm{~cm}$ in length. The larger QMI are disc-shaped, unlike the typical spheroidal shape of Glass Mountain and Little Glass Mountain inclusions and those described by Bacon (1986). Lower-silica host samples show abundant microscopic crystal clots containing plagioclase, olivine, and clinopyroxene, whereas the higher-silica samples display far fewer tiny inclusions, suggesting that the compositional variation is most likely caused by disaggregation of mafic magmatic inclusions. The rhyolite of the Hoffman flows is the most porphyritic of the three late Holocene rhyolites. Photomicrographs of thin sections are shown in figure 36 . The highest-silica (and thus least mixed) samples contain 5-10 percent of 1-2 $\mathrm{mm}$ plagioclase phenocrysts, plus $\sim 1$ percent of $1 \mathrm{~mm}$ orthopyroxene and $<1 \mathrm{~mm}$ magnetite.
A variety of inclusions were collected from the two areas of lava flow, among them one cumulate inclusion and eight QMI. No plutonic-textured fragments were seen. Among the eight analyzed QMI, two distinct types are present: (1) two andesitic inclusions containing plagioclase phenocrysts have 55.9 and 57.9 weight percent $\mathrm{SiO}_{2}$ and resemble the wet calcalkaline QMI that are present in Glass Mountain and Little Glass Mountain lavas; (2) five of the much more abundant fine-grained, nearly aphyric basaltic inclusions have 49.6 to 51.6 weight percent $\mathrm{SiO}_{2}$. QMI with basaltic compositions are rare (Bacon, 1986) and QMI with such low silica contents are absent from the other late Holocene rhyolites, although they are present in the $\sim 3$-ka andesitic Burnt Lava Flow. These low- $\mathrm{SiO}_{2}$ inclusions resemble dry tholeiitic magmas like those described by Hart and others (1984) who labeled them HAOT (high-alumina olivine tholeiite). Thus both wet calcalkaline and dry tholeiitic magmas were present beneath the volcano.

One cumulate inclusion (1044M-a, table 1) was analyzed and is shown in figure $36 E, F$ along with photomicrographs of host lavas and one fine-grained basaltic QMI.



Figure 35. Aerial view west across the northern domes of the Glass Mountain fissure in the foreground to the northern part of the Hoffman flows in the center of view. The rhyolitic Hoffman flows erupted about three centuries prior to the Glass Mountain eruption along a parallel north-northwest-trending fissure. Just beyond the northern Hoffman flow is Mount Hoffman, the highest point on the rim of Medicine Lake volcano at $\sim 8,000 \mathrm{ft}$. $(2438 \mathrm{~m})$ and the dome of a late Pleistocene rhyolite flow. To the left of Mount Hoffman, near the edge of the photo and surrounded by trees is Medicine Lake. Snow-covered Mount Shasta is seen on the horizon. 


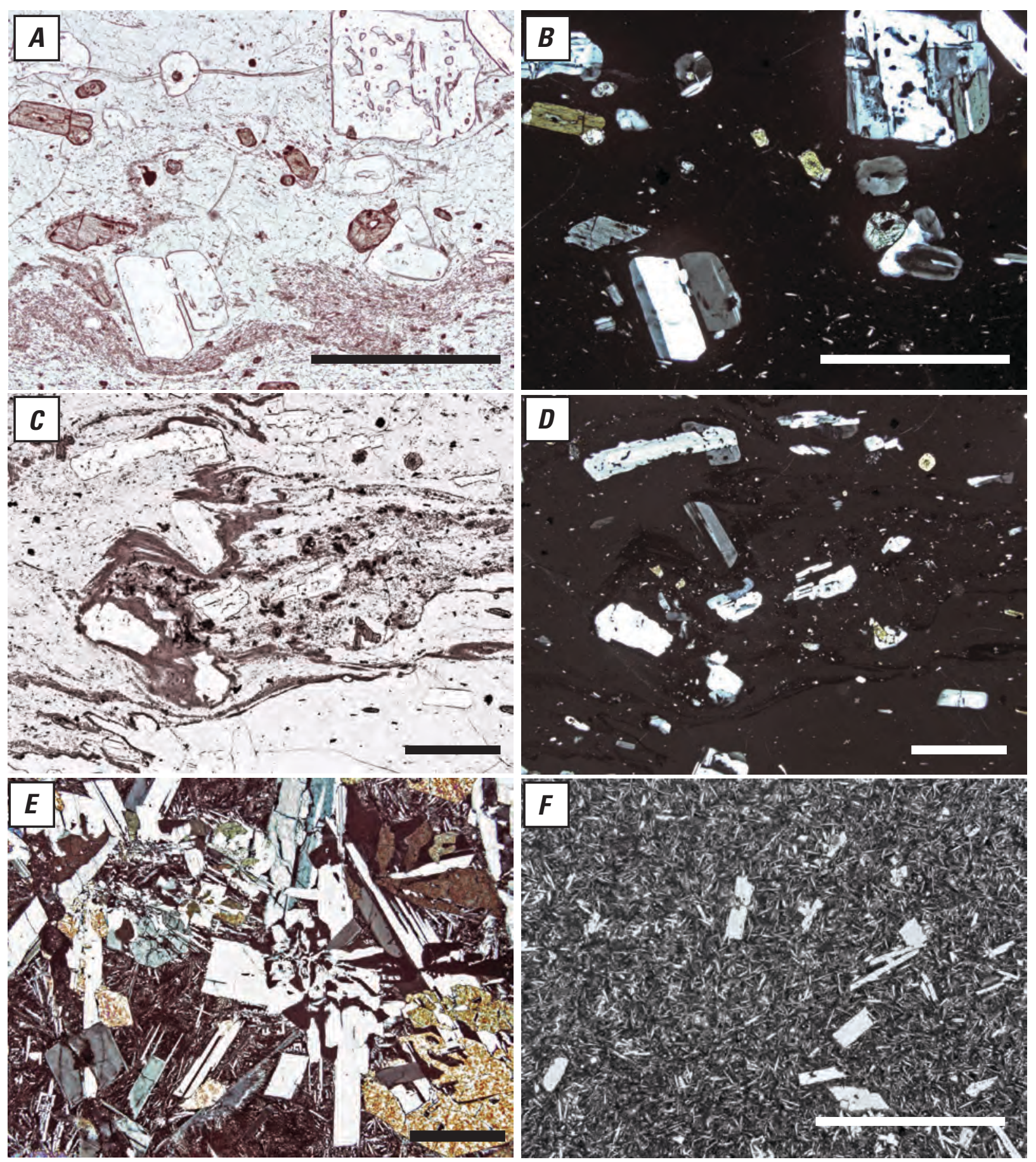

Figure 36. Photomicrographs of the host lava and inclusions from the Hoffman flows. Views $A-D$ are of host lava sample $26 \mathrm{M}$ (71.8 weight percent $\left.\mathrm{SiO}_{2}\right)$. $(A, B)$ Plane and crossed-polarized light images showing plagioclase phenocrysts along with microphenocrysts of plagioclase and pyroxene in a glassy matrix that displays zones with flow-aligned microlites that wrap around crystals. $(C, D)$ Plane and crossed-polarized light images showing a wider view and apparent mingling of different glass compositions. (E) crossed-polarized light image of cumulate inclusion sample 1044M-a (47.8 weight percent $\mathrm{SiO}_{2}$ ) with intergrown olivine and plagioclase phenocrysts set in a matrix displaying rapid growth morphologies in small plagioclase; ( $F$ A fine-grained basaltic inclusion (sample 1652M, 51.6 weight percent $\mathrm{SiO}_{2}$ ), in plane light, displays some microphenocrysts of plagioclase in a groundmass dominated by plagioclase microlites. Scale bars are each $1 \mathrm{~mm}$ in length. Chemical analyses are in table 1. 


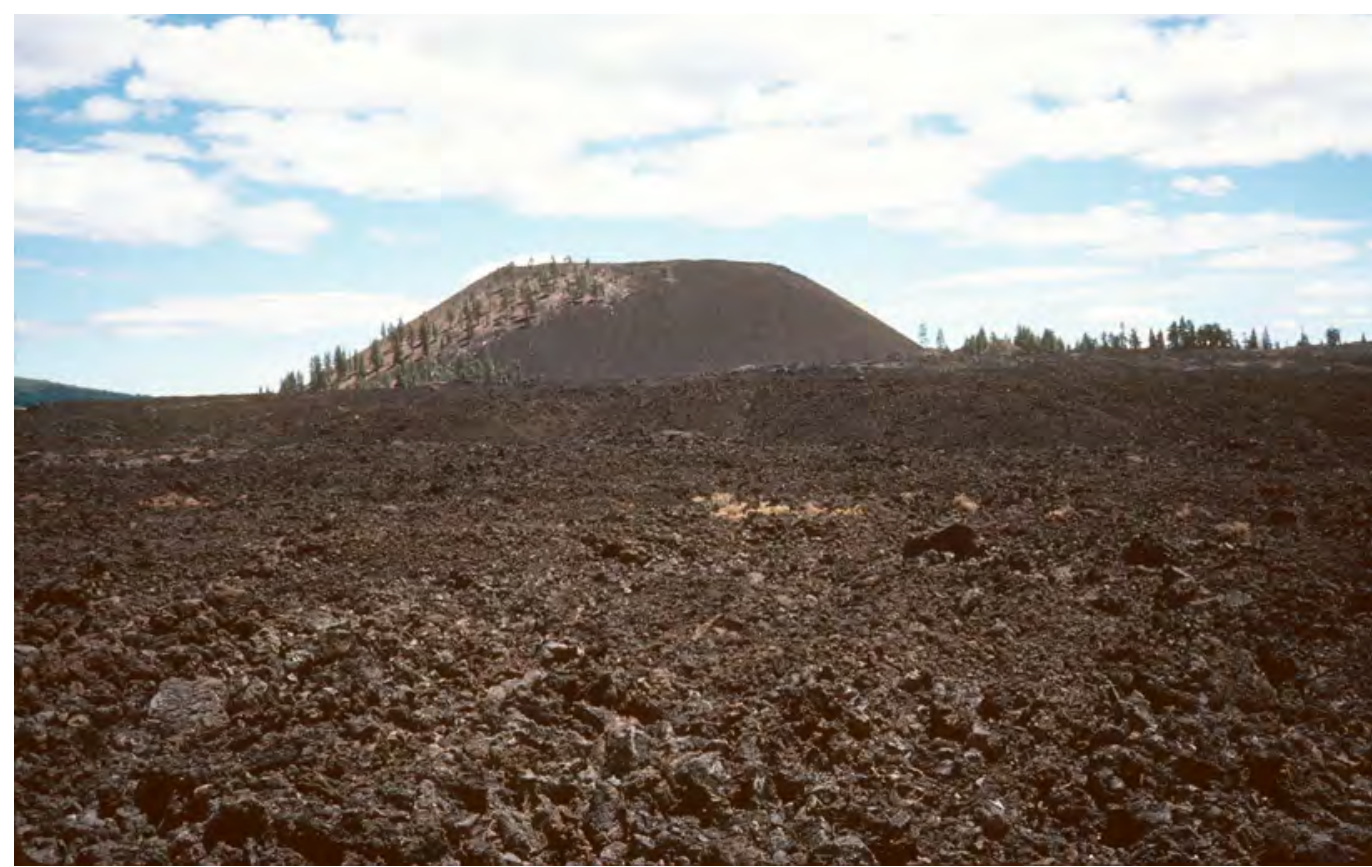

Figure 37. Photograph of High Hole Crater, vent for the 3-ka Burnt Lava Flow, as seen across a part of this blocky andesite flow.

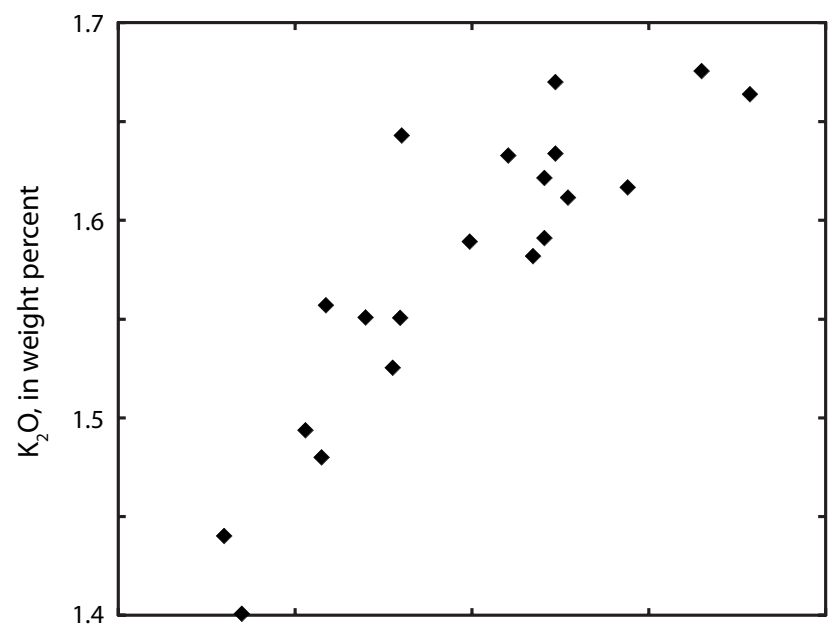

\section{The 3-ka Episode}

Nearly two millenia prior to the $\sim 1$ ka eruptive episode, two eruptions took place within a brief time span of $\sim 130$ years (Nathenson and others, 2007). The andesite of the Burnt Lava Flow erupted on the south flank and was preceded by the basalt of Black Crater and Ross Chimneys on the far north flank (fig. 4A). The total erupted volume for this episode was just over $0.5 \mathrm{~km}^{3}$, nearly all of it in the Burnt Lava Flow. The area covered by eruptions during this episode was $34.75 \mathrm{~km}^{2}$, including $0.45 \mathrm{~km}^{2}$ for the basalt of Black Crater and Ross Chimneys. Both of the eruptions generated spatter vents that were readily sampled for their paleomagnetic directions. These units also display compositional zonation, with the most mafic lava erupting early in both cases.

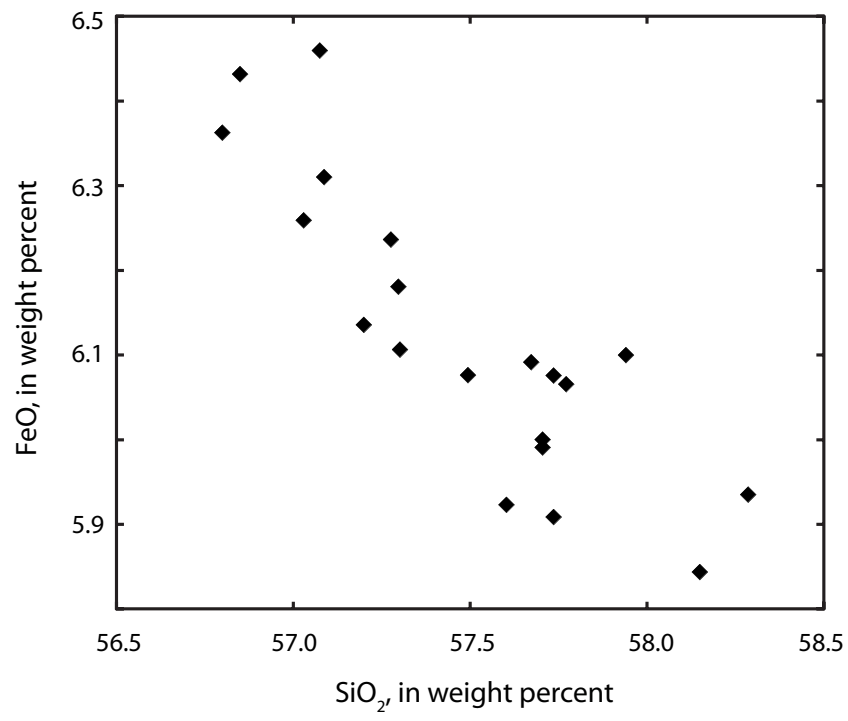

\section{Burnt Lava Flow}

This rugged, mostly unvegetated lava flow has an estimated volume of $0.5 \mathrm{~km}^{3}$. Lava erupted from a north-south alignment of vents including High Hole Crater (fig. 37) and covered $34.3 \mathrm{~km}^{2}$. Early explosive activity built the large cinder cone, but no evidence of a tephra has been found beyond the limits of the lava flow. Because of its youthful appearance, this flow was originally thought to have erupted as recently as 300 years ago (Finch, 1933), but charcoal retrieved from a large tree mold in a distal flow lobe indicated that the eruption occurred about 3,010 years ago. Silica content of the lava flow ranges from 56.8 to 58.3 weight percent based on 20 analyzed samples (Grove and others, 1988). Plots of $\mathrm{SiO}_{2}$ versus $\mathrm{FeO}$ and $\mathrm{K}_{2} \mathrm{O}$ (fig. 38) show that cryptic compositional variation is present, although no attempt was made to map out the areal distribution of the compositional range because of limited petrographic variability in the field. However, examination of

Figure 38. Plots showing compositional variability in the Burnt Lava Flow. Data available in table 1 and in Grove and others (1988). 

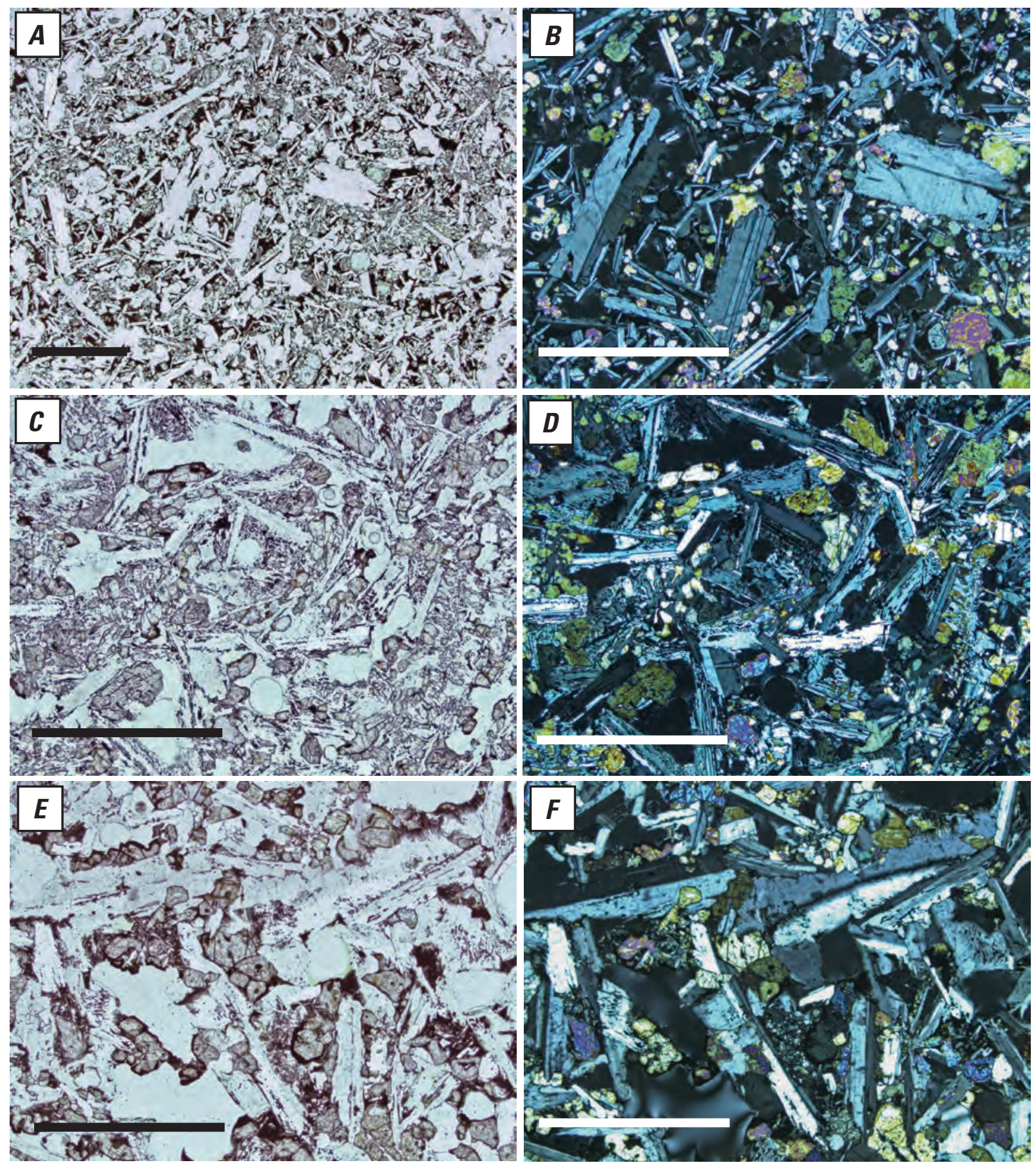

Figure 39. Photomicrographs of quenched basaltic inclusions in the Burnt Lava Flow. Plane light (left) and crossedpolarized light (right) views of three quenched magmatic inclusions. $(A, B)$ sample $659 \mathrm{M}$ (48.4 weight percent $\mathrm{SiO}_{2}$ ); $(C, D)$ sample $695 \mathrm{Mb}\left(47.9\right.$ weight percent $\left.\mathrm{SiO}_{2}\right)$, and $(E, F)$ sample $1156 \mathrm{M}$ (49.4 weight percent $\left.\mathrm{SiO}_{2}\right)$. Elongate euhedral plagioclase and smaller olivine crystals are accompanied by interstitial clinopyroxene in all samples. The chilled texture and rapid growth morphologies are best seen in $(C, D)$. Additional images and petrographic descriptions are in Grove and others (1988). Scale bars are each $1 \mathrm{~mm}$ in length. Chemical analyses are in table 1.

aerial photos together with the known locations of the analyzed samples in Grove and others (1988) indicates that the lava erupted earlier is more mafic than later lobes.

A photomicrograph of one sample (fig. $33 E$ ) shows the compositionally and texturally diverse population of crystals that record fractional crystallization, assimilation, and magma mixing processes that gave rise to the andesite of Burnt Lava Flow. The inclusions are typically fine-grained and aphyric with a crystalline groundmass (fig. 39). Partly melted granitoid inclusions were also found in this flow (table 2). Additional 


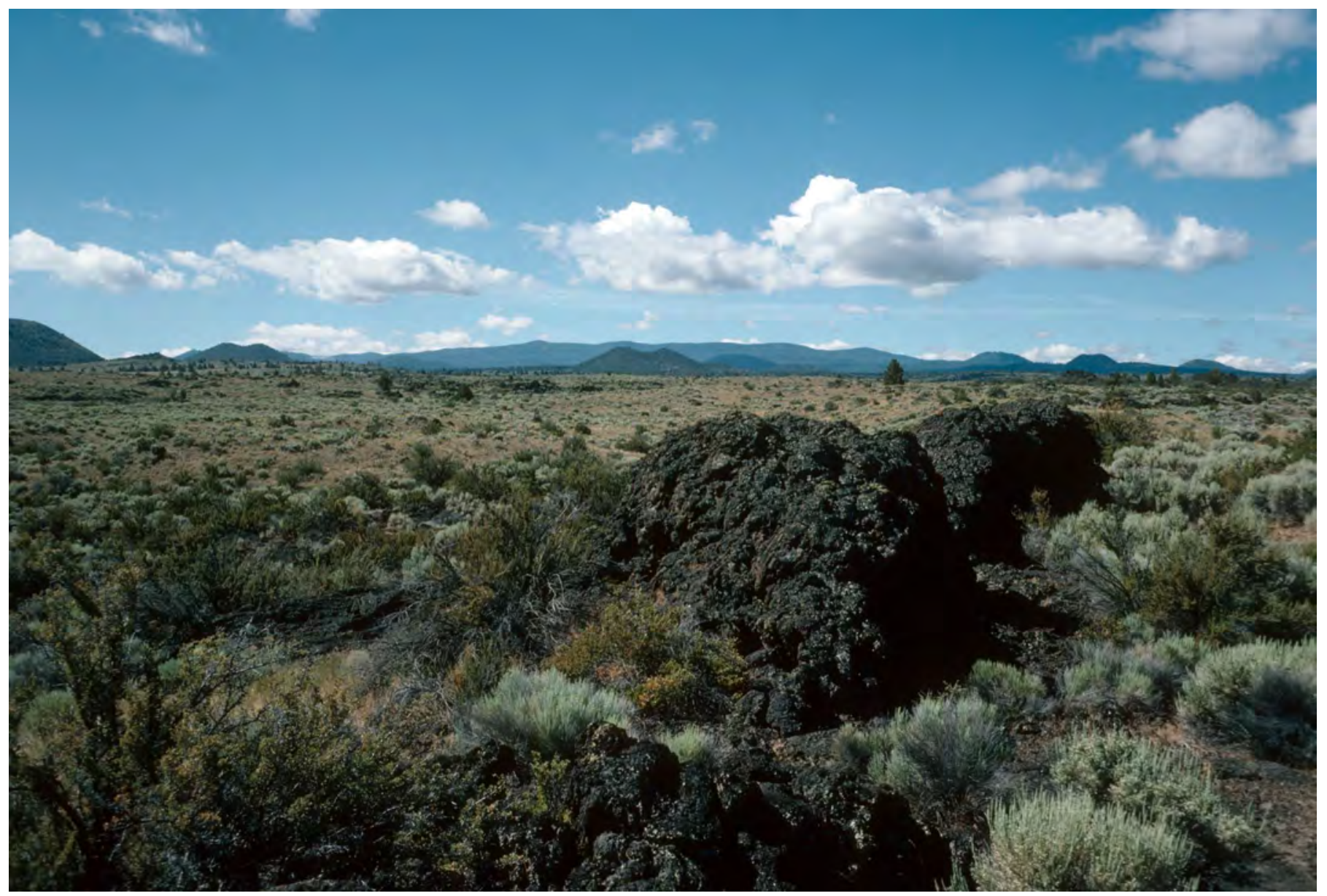

Figure 40. Photograph of the uppermost Ross Chimneys spatter vents in northern Lava Beds National Monument. This view looking south shows numerous flank cinder cones and the top of Medicine Lake volcano on the horizon.

photomicrographs and more detailed petrographic descriptions can be found in Grove and others (1988).

Five analyses of host rocks, along with seven analyses of inclusions are included in table 1 . Six analyzed basaltic inclusions range in composition from 48.4 to 49.6 weight percent $\mathrm{SiO}_{2}$. One inclusion with 51.7 weight percent $\mathrm{SiO}_{2}$ shows physical evidence of contamination by andesite or melted granite (Grove and others, 1988). These QMI are similar in composition to the basaltic QMI in the later Hoffman flows and to high-alumina olivine tholeiites (HAOT of Hart and others, 1984) that have erupted intermittently throughout the history of MLV.

\section{Basalt of Black Crater and Ross Chimneys}

Numerous spatter vents (fig. 40) scattered along a 2.5-kmlong north-northeast-trending fissure produced two very small areas of basalt flows (Donnelly-Nolan and Champion, 1987; Donnelly-Nolan, 2010) that together cover $0.45 \mathrm{~km}^{2}$ on the lower north flank of MLV (figs. $4 A$ and 41). The lavas are compositionally similar to basaltic QMI in the Burnt Lava Flow and in the Hoffman flows. The total volume of the two thin flows that erupted $\sim 3,140$ years ago is $\sim 0.001 \mathrm{~km}^{3}$. This is the only late Holocene eruption to have taken place within the boundary of Lava Beds National Monument (see fig. 3).

Despite the small volume of the eruption and the limited compositional span (48.3 to 50.6 weight percent $\mathrm{SiO}_{2}$ ), compositional variation as a function of latitude is clearly recorded (fig. 41). Lava from the upper (southern) Black Crater vents overlies lava from the lower (northern) Black Crater vents suggesting that higher-silica lava erupted after lower-silica lava. No stratigraphic relationship was recognized within the separate Ross Chimneys lava to the north, but if the relationship holds that higher-silica lavas erupted later than lowersilica lavas, then the eruption apparently propagated from 

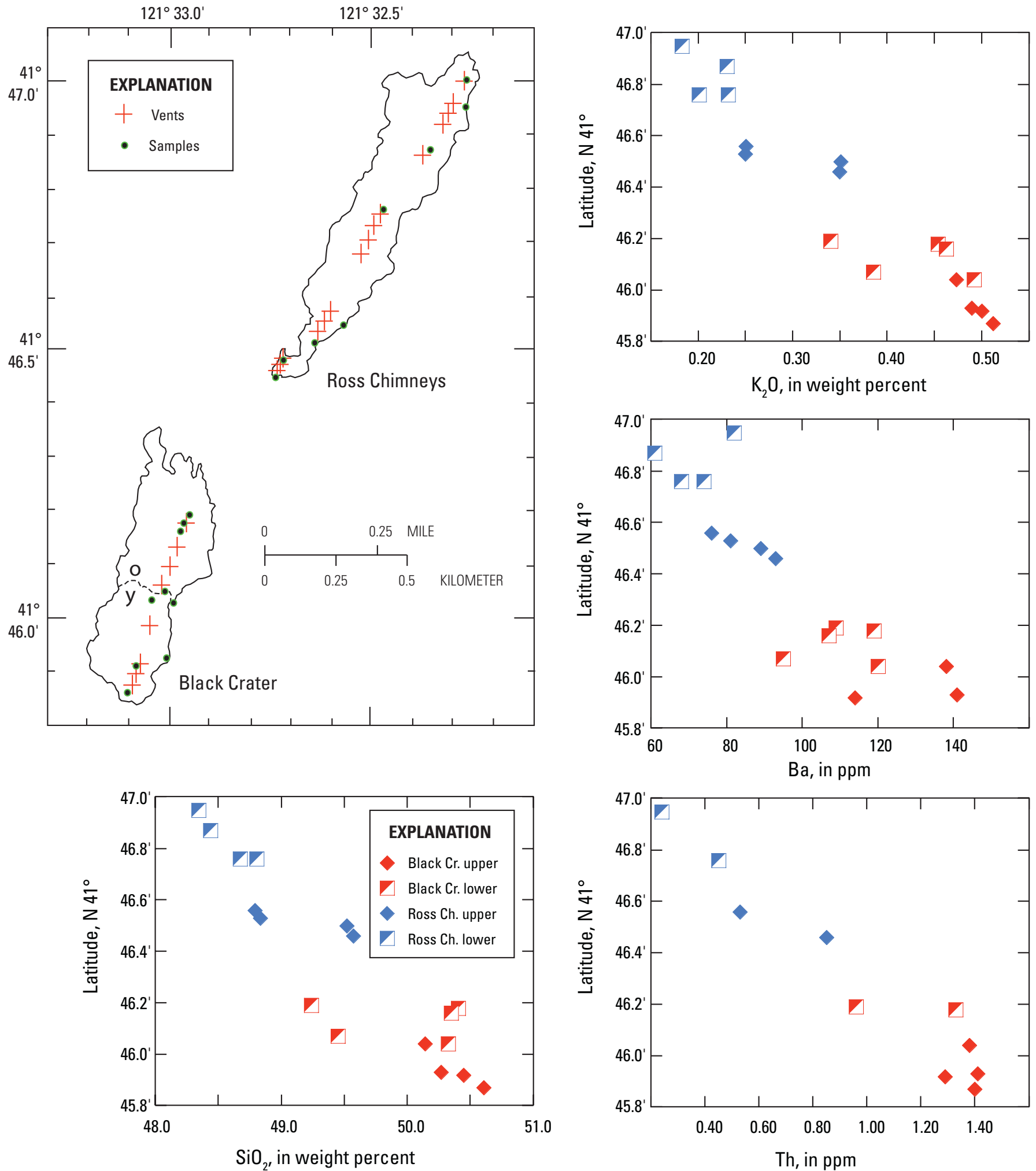

Figure 41. Outline map of the $\sim 3-k a$ basalt of Black Crater and Ross Chimneys. Vents for this small fissure eruption are shown with red crosses; sample locations with green dots, and younger (y) - older (o) relationship shown for southern part of the eruption. Accompanying the map are four plots showing chemical components versus latitude demonstrating a correlation between spatial position along the fissure and composition. Chemical analyses and location coordinates are in table 1. 


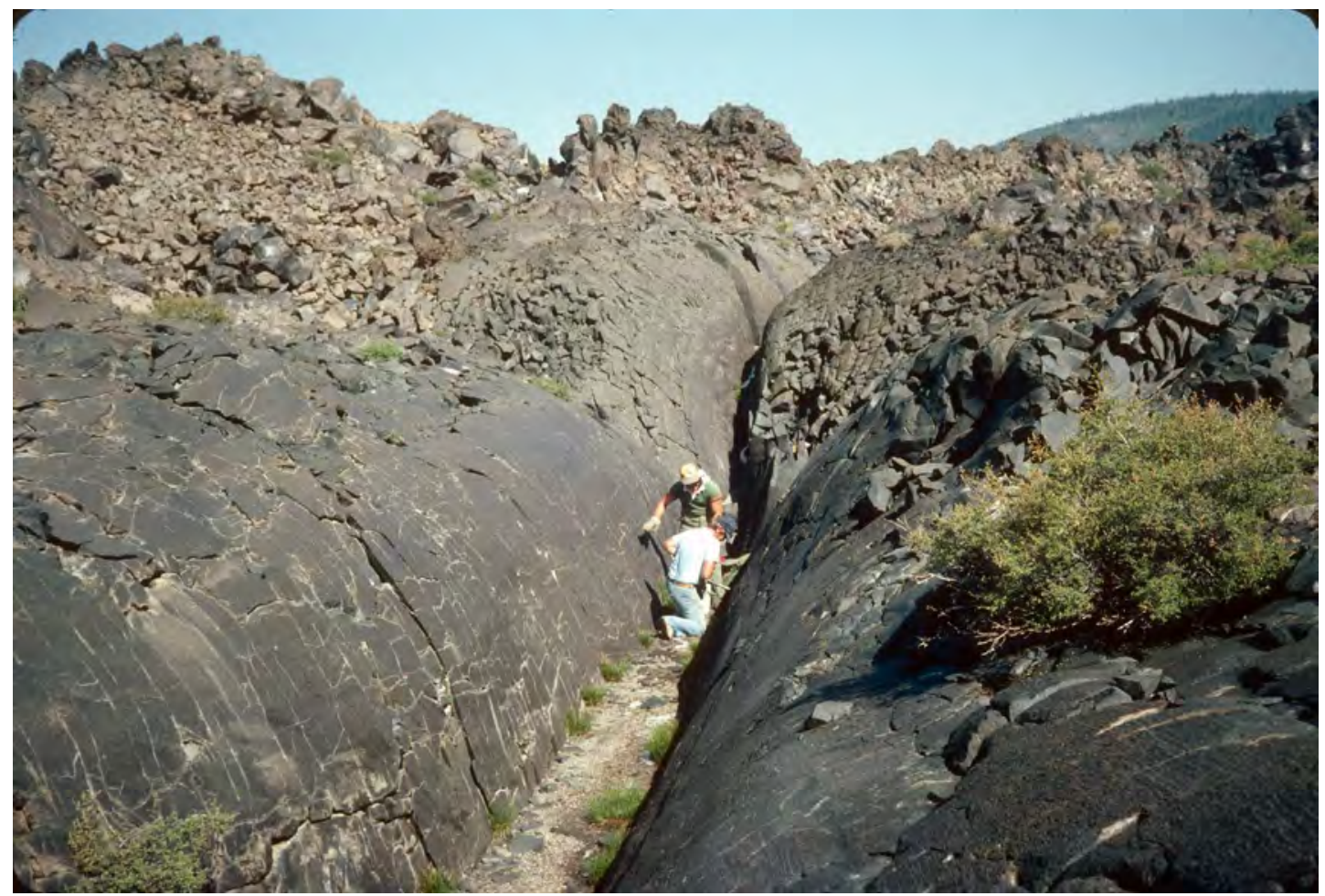

Figure 42. Paleomagnetic drilling in a crease structure on the surface of the Medicine Lake Glass Flow (site 4B306).

north to south. North-northeast-trending faults and large open ground cracks north of the lavas and on trend with the vents suggest that an extensional episode likely tapped the magma, allowing it to rise to the surface. The compositional variability recorded in the eruption likely resulted from mixing of dry tholeiitic parent basalt with more silicic evolved magma. Work by Sisson and Layne (1993) showed that glass inclusions within Black Crater olivines have very low $\mathrm{H}_{2} \mathrm{O}$ content $(<0.3$ weight percent).

Variation diagrams in figure 41 show that enrichments of some elements are pronounced when comparing the lowestto highest-silica lavas, for example, $\mathrm{K}_{2} \mathrm{O}$ more than doubled ( 0.18 to 0.51 weight percent), as did $\mathrm{Ba}(61 \mathrm{ppm}$ to $141 \mathrm{ppm})$ and Th (0.24 to $1.4 \mathrm{ppm})$ (table 1). A small, zoned magma reservoir or contaminated dike-like body is implied by the data. The porphyritic nature of the basalt ( $\sim 25$ percent of 1-4 mm phenocrysts with plagioclase much more abundant than olivine) suggests a protracted residence time for crystallization in the crust before eruption. The location of this unit is more than $20 \mathrm{~km}$ from the center of MLV, indicating the broad impact of the Medicine Lake magmatic system in late Holocene time.

\section{The 5-ka Episode}

Two small caldera-focused dacite eruptions (fig. 4) were the first lavas to reach the surface at MLV following the widespread 12.5-ka basaltic episode (fig. 3). The Medicine Lake
Glass Flow erupted nonexplosively near the northwest wall of the caldera. The lower-silica dacite of pit craters, by contrast, erupted explosively from a fissure at the southeastern caldera margin. The estimated total volume for the two eruptions is $\sim 0.1 \mathrm{~km}^{3}$ and the area covered was $\sim 4.8 \mathrm{~km}^{2}$. No stratigraphic constraints exist to establish the relative ages of the two dacites. Radiocarbon ages suggest that the dacite of pit craters is the younger and that less than $\sim 100$ years elapsed between the two eruptions (Nathenson and others, 2007). Very similar paleomagnetic directions also support the short time interval. Welded spatter in the wall of one pit crater and in a roadcut near another pit crater provided opportunities for paleomagnetic sampling. However, paleomagnetic sampling of Medicine Lake Glass Flow with its steep marginal talus-covered slopes was more challenging. Crease structures (Anderson and Fink, 1992) on the surface (fig. 42) eventually yielded a successful magnetic direction.

\section{Dacite of Pit Craters}

The low-silica dacite of the pit craters (63.1weight percent $\mathrm{SiO}_{2}$ ) erupted explosively $\sim 5,100$ years ago as nearly aphyric spatter from a northeast-trending fissure at the southeastern margin of the caldera. The fissure is marked by a nearly 3-km-long set of explosion craters rimmed by welded, phenocryst-poor (fig. $43 \mathrm{~A}$ ) dacite spatter. The thickness, degree of welding, and size of individual fragments in the deposit decreases rapidly away from the craters. The area mapped as blanketed by the eruption (Donnelly-Nolan, 2010) 

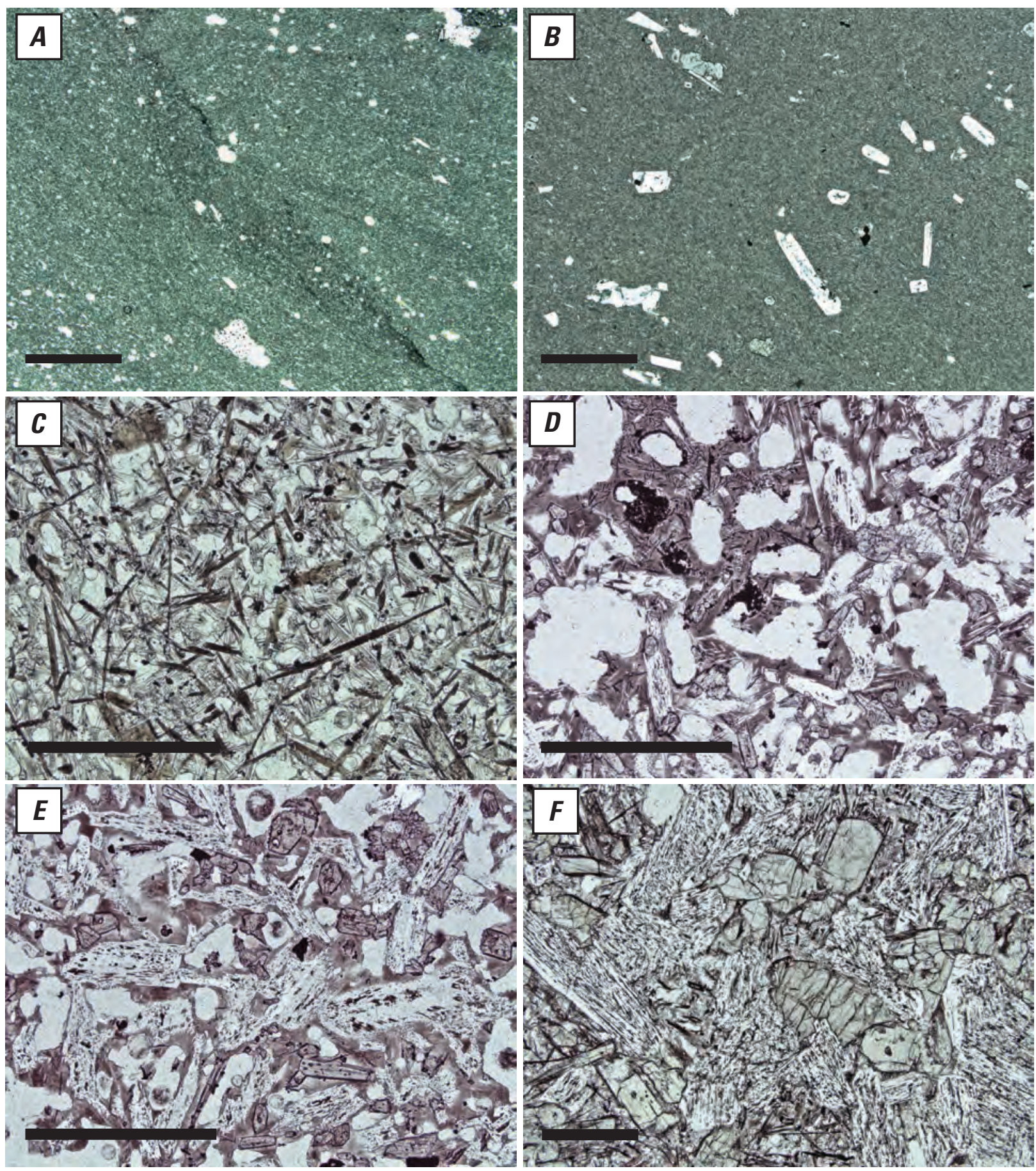

Figure 43. Photomicrographs of the $\sim 5$-ka dacitic lavas and inclusions. (A) Sample $110 \mathrm{M}$, the dacite of pit craters (63.4 weight percent $\mathrm{SiO}_{2}$ ) displays microphenocrysts of plagioclase set in a groundmass showing abundant small crystals (mostly plagioclase?) in plane light. ( $B$ - $F$ ) Samples from Medicine Lake Glass Flow; (B) Host lava sample 45M (68.5 weight percent $\mathrm{SiO}_{2}$ ) that shows phenocrysts of plagioclase and smaller pyroxene in glassy groundmass displaying incipient crystallization. $(C-E)$ Views of quenched magmatic inclusions. (C) Plane light view of sample $1151 \mathrm{M}$-c (61.6 weight percent $\left.\mathrm{SiO}_{2}\right)$ that shows needles of hornblende together with less obvious needles of colorless plagioclase and pyroxene and small equant Fe-Ti oxides in a clear, glassy vesicular groundmass. (D) Plane light view of sample 1117M ( 59.0 weight percent $\mathrm{SiO}_{2}$ ) that shows abundant white areas of vesicles; crystals are plagioclase and pyroxene, many elongate, and are set in a matrix of brownish glass. (E) Plane light view of sample $1631 \mathrm{M}$ (57.9 weight percent $\mathrm{SiO}_{2}$ ) dominated by elongate mottled plagioclase crystals together with smaller and less abundant orthopyroxene crystals in a matrix of brownish vesicular glass. ( $F$ C Cumulate inclusion sample $1151 \mathrm{M}$-a $\left(56.3\right.$ weight percent $\mathrm{SiO}_{2}$ ) in plane light view displays a coarse texture of intergrown mottled plagioclase, pyroxene, and olivine; elongate brown needles of hornblende can be seen in the interstitial finergrained matrix. Scale bars are each $1 \mathrm{~mm}$ in length. Chemical analyses are in table 1. 
covers $2.4 \mathrm{~km}^{2}$ although a thin tephra deposit extends beyond the mapped area. The erupted volume is $\sim 0.02 \mathrm{~km}^{3}$.

The erupted lava is considered homogeneous based on two chemical analyses (table 1) and the lack of petrographic variability. Except for small and rare angular lithic fragments, the unit apparently lacks inclusions.

\section{Medicine Lake Glass Flow}

The age of the Medicine Lake Glass Flow was previously estimated at $\sim 2,000$ yrs B.P. (Donnelly-Nolan and others, 1990). However, more recent studies (as discussed in Nathenson and others, 2007) of lake sediments in nearby Medicine Lake indicate that a thin layer found in the sediments matches the flow in composition. No mappable tephra deposit from this eruption was identified, suggesting that the eruption was characterized dominantly by quiescent flow emplacement. Its age is constrained by radiocarbon dating and an apparently linear sedimentation rate in the Medicine Lake sediments at $\sim 5,200$ years ago. The pancake-like dacite flow (fig. 44) erupted from two vents that trend N. $45^{\circ} \mathrm{W}$. near the northwest wall of the caldera. It covers $\sim 2.4 \mathrm{~km}^{2}$ and has an estimated volume of $0.08 \mathrm{~km}^{3}$. No compositional zonation is evident based on three very similar chemical analyses

(68.2-68.8 weight percent $\mathrm{SiO}_{2}$, table 1) and homogeneous petrographic appearances. Glassy flow rocks are noticeably porphyritic with $\sim 5$ percent of $1-3 \mathrm{~mm}$ plagioclase and $<1$ percent of 1-2 $\mathrm{mm}$ orthopyroxene. A photomicrograph is shown as figure $43 B$.

The flow hosts a sparse and interesting suite of magmatic inclusions including QMI ranging in silica content from 57.9 to 61.6 weight percent as well as cumulate-textured inclusions (Mertzman and Williams, 1981; Grove and Donnelly-Nolan, 1986). Gabbroic and granitic inclusions similar to those in Glass Mountain lavas are also present (table 2, fig. 20). Chemical analyses of host rocks, four QMI, and one cumulate magmatic inclusion are presented in table 1. Photomicrographs of three amphibole-bearing fine-grained andesitic QMI and one cumulate inclusion are shown as figure $43 C-F$. These inclusions record fractional crystallization, assimilation, and magma mixing processes similar to those documented in the Glass Mountain and Little Glass Mountain lavas. The presence of amphibole provides evidence of wet calcalkaline parentage.

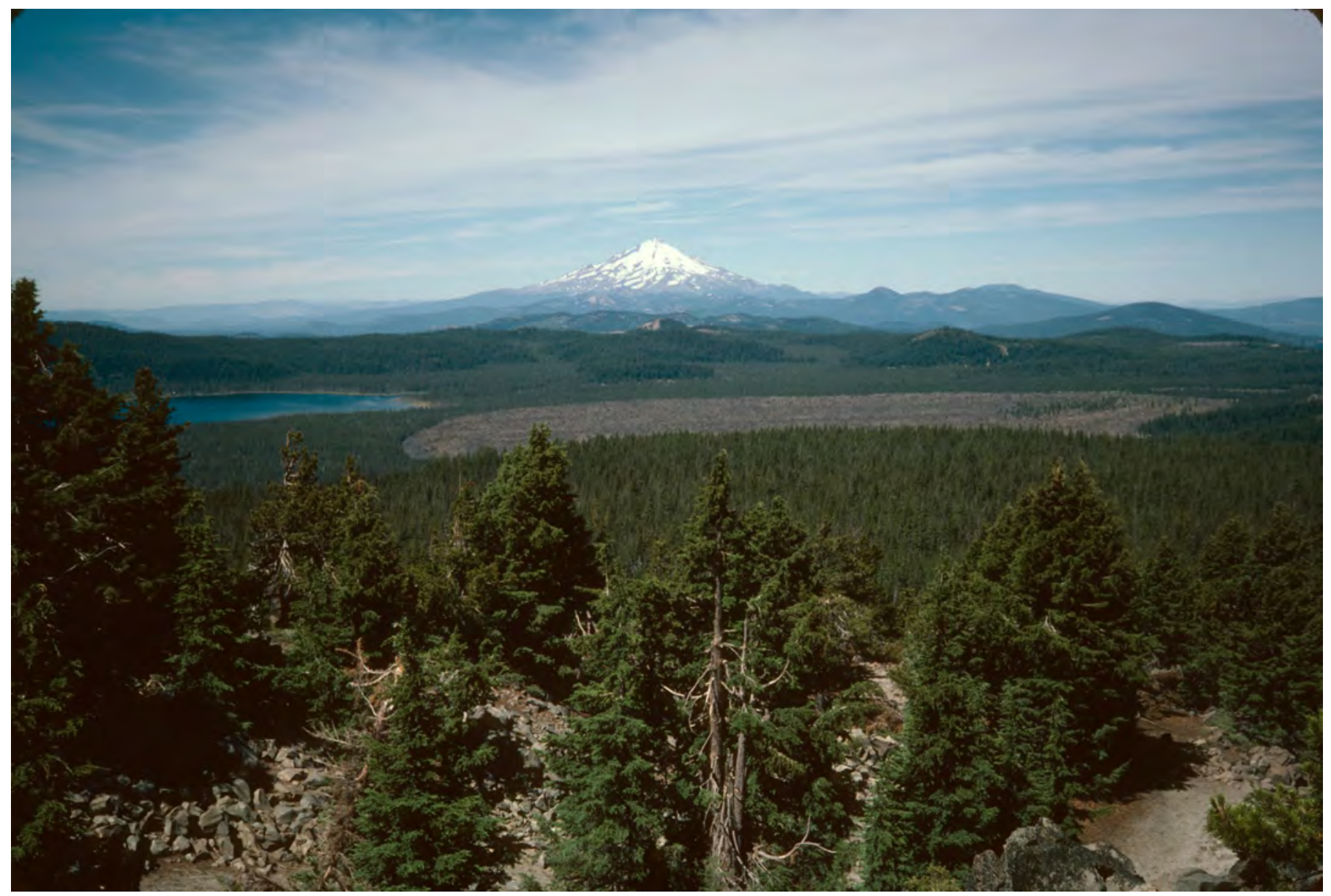

Figure 44. View west-southwest from Mount Hoffman, the highest point on the rim of Medicine Lake caldera, toward Mount Shasta. Medicine Lake Glass Flow is the unforested brown area in center of view. Part of Medicine Lake can be seen to the left of the flow. 


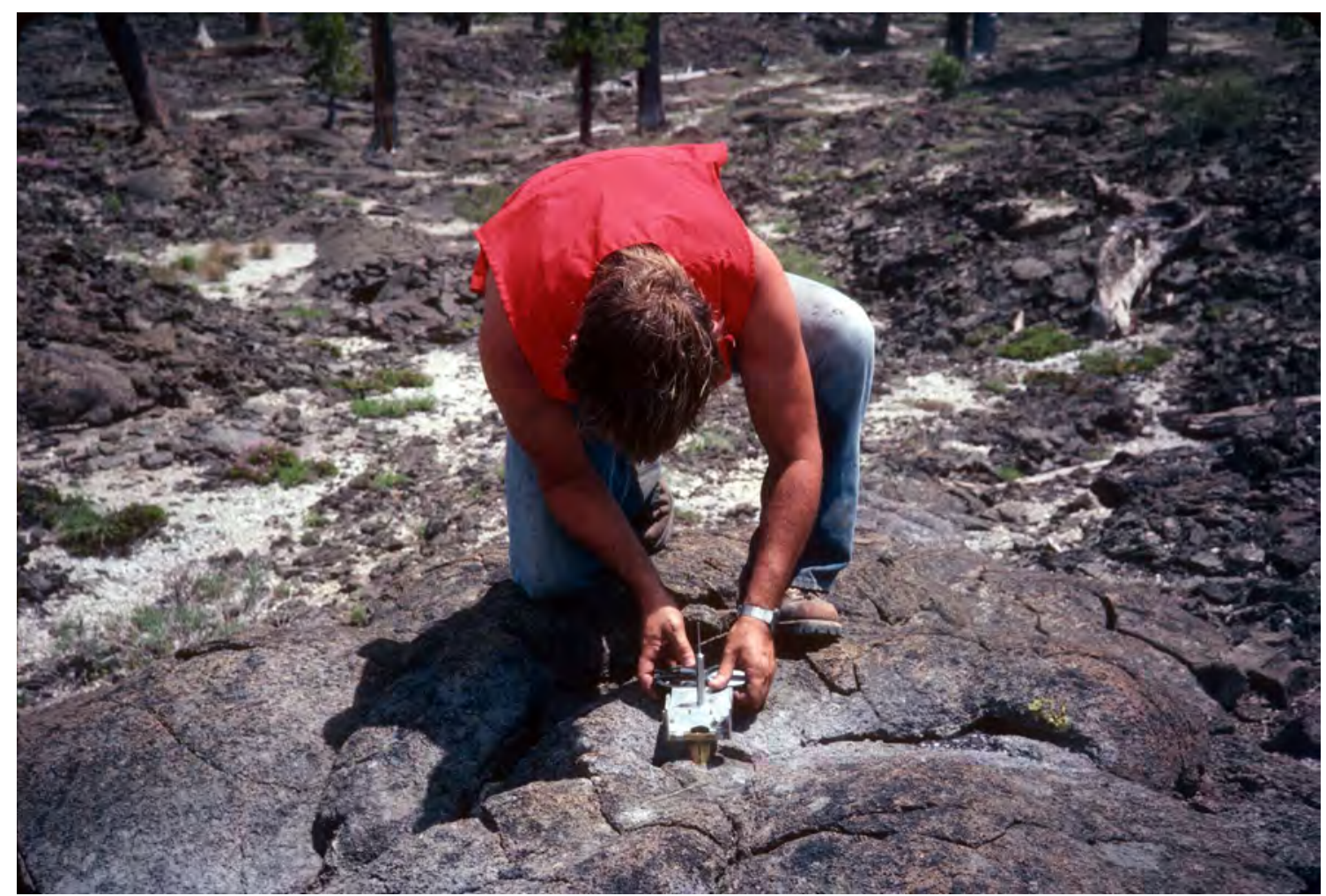

Figure 45. Photograph showing the use of a sun compass to orient core samples collected for paleomagnetic study.

\section{Identifying the Timing of the Eruptions Using Paleomagnetism}

Most late Holocene units preserved material that could be dated by radiocarbon, but large measured errors in some ages, combined with the difficulty of assessing multiple disparate age samples, and the lack of datable material for some units led to uncertainties in the ages (Nathenson and others, 2007). In order to better constrain the eruption ages of the late Holocene lavas and the time intervals between them, we utilized paleomagnetism to determine and compare their magnetic directions. Our goals included (1) using the paleomagnetic directions to constrain the ages of otherwise undated eruptive events using geomagnetic secular variation and then comparing measured directions to the magnetic directions of dated lava flows at nearby volcanic centers, (2) identifying brief episodes of activity in cases where lava flows have overlapping magnetic directions, and (3) investigating possible extended time spans of individual eruptions (for example, Champion and Donnelly-Nolan, 1994; Turrin and others, 1998; Muffler and others, 1994). We then used records of secular variation in the Western U.S. (Champion, 1980; Hagstrum and Champion, 2002) to clarify the ages of the late Holocene eruptive products, some of which were imprecisely determined or undated by radiocarbon (Nathenson and others, 2007).

We sought rock outcrop environments where the collection of oriented core samples would provide information about the direction of the magnetic field at the time the lava cooled below its Curie temperature. One-inch-diameter cores were oriented in the field using a sun compass (fig. 45), followed by laboratory analysis at the U.S. Geological Survey in Menlo Park, Calif. Obtaining highly precise directions of magnetization from viscous, high-aspect-ratio lava flows, such as the young rhyolite flows that are surrounded by steep talus-dominated slopes and mostly covered with spines and loose blocks was a significant challenge (Champion and Donnelly-Nolan, 2008). More fluid lava flows of mafic composition provide better opportunities for sampling relatively quickly chilled and unrotated magmatic products. Identifying fluid or plastic behavior in the dominantly brittle environment of silicic flows, however, can be problematic. In many cases, the viscous silicic lava flows continue to move after the exterior carapace has cooled below its Curie temperature. In the absence of any erosion or artificial cuts that expose the interior of rhyolite lava flows under a typical mantle of blocky chaos, a variety of possible outcrops and materials were tested to identify environments that preserved a stable direction and could be sampled effectively.

Sample locations are shown in figure 46; successful and unsuccessful sampling attempts are also listed in table 3 (online only). Unsuccessful sites are included in the table for completeness and are shown both in the table and on the map with parentheses. Forty-three sites were attempted, of which eight were considered to be failed sites. Well-grouped directional information was obtained from two or more sites in each late Holocene unit with the exception of the Medicine Lake Glass Flow, where just one site was successful. 


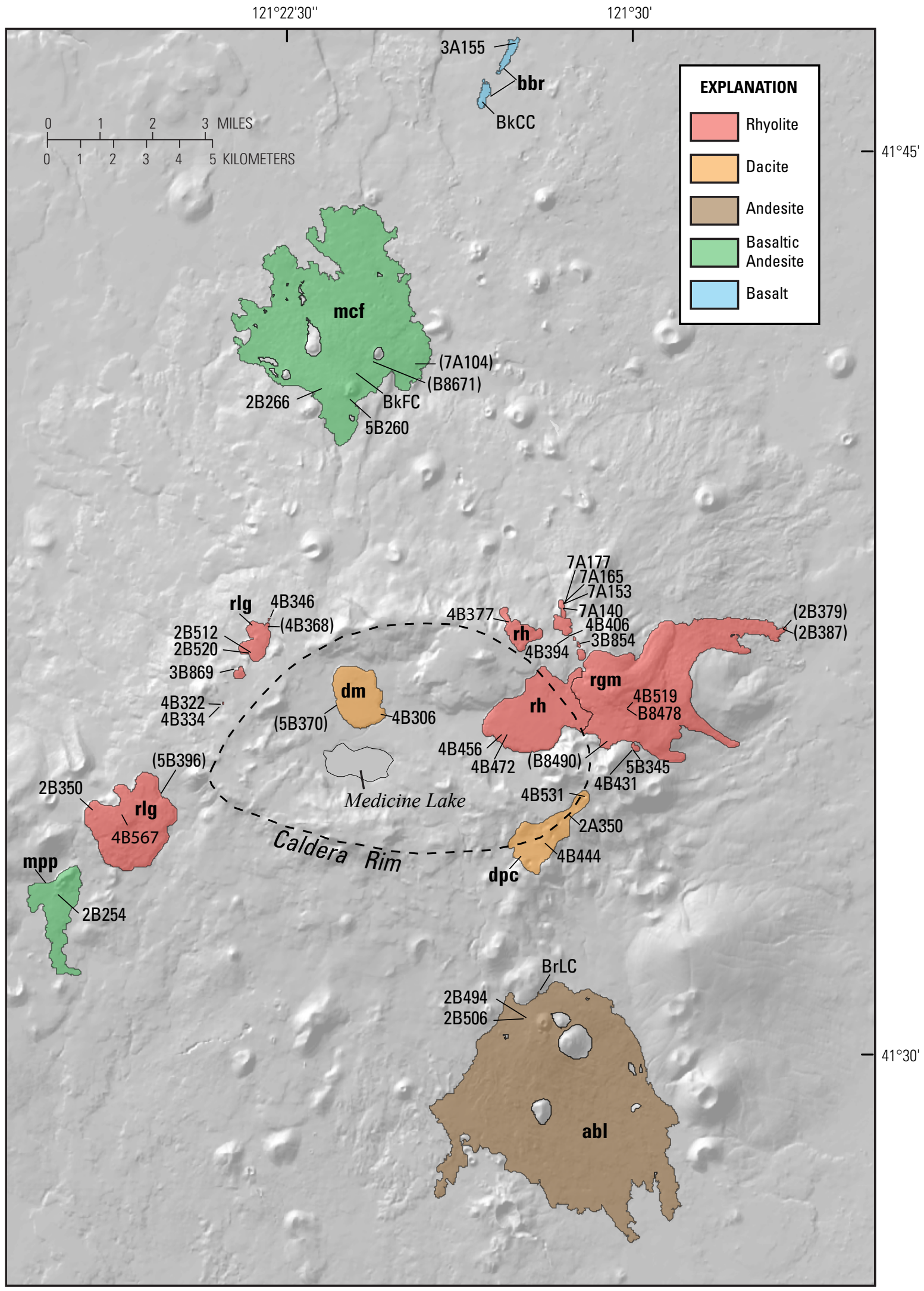

Figure 46. Map showing paleomagnetic site locations listed in table 3. Paleomagnetic sites in parentheses were attempted, but considered to be failed sites. Unit symbols are from Donnelly-Nolan (2010); rhyolite of Glass Mountain, rgm; rhyolite of Little Glass Mountain, rlg; basaltic andesite of Paint Pot Crater, mpp; basaltic andesite of Callahan Flow, mcf; rhyolite of Hoffman flows, rh; andesite of Burnt Lava Flow, abl; basalt of Black Crater and Ross Chimneys, bbr; dacite of pit craters, dpc; dacite of Medicine Lake Glass Flow, dm. 


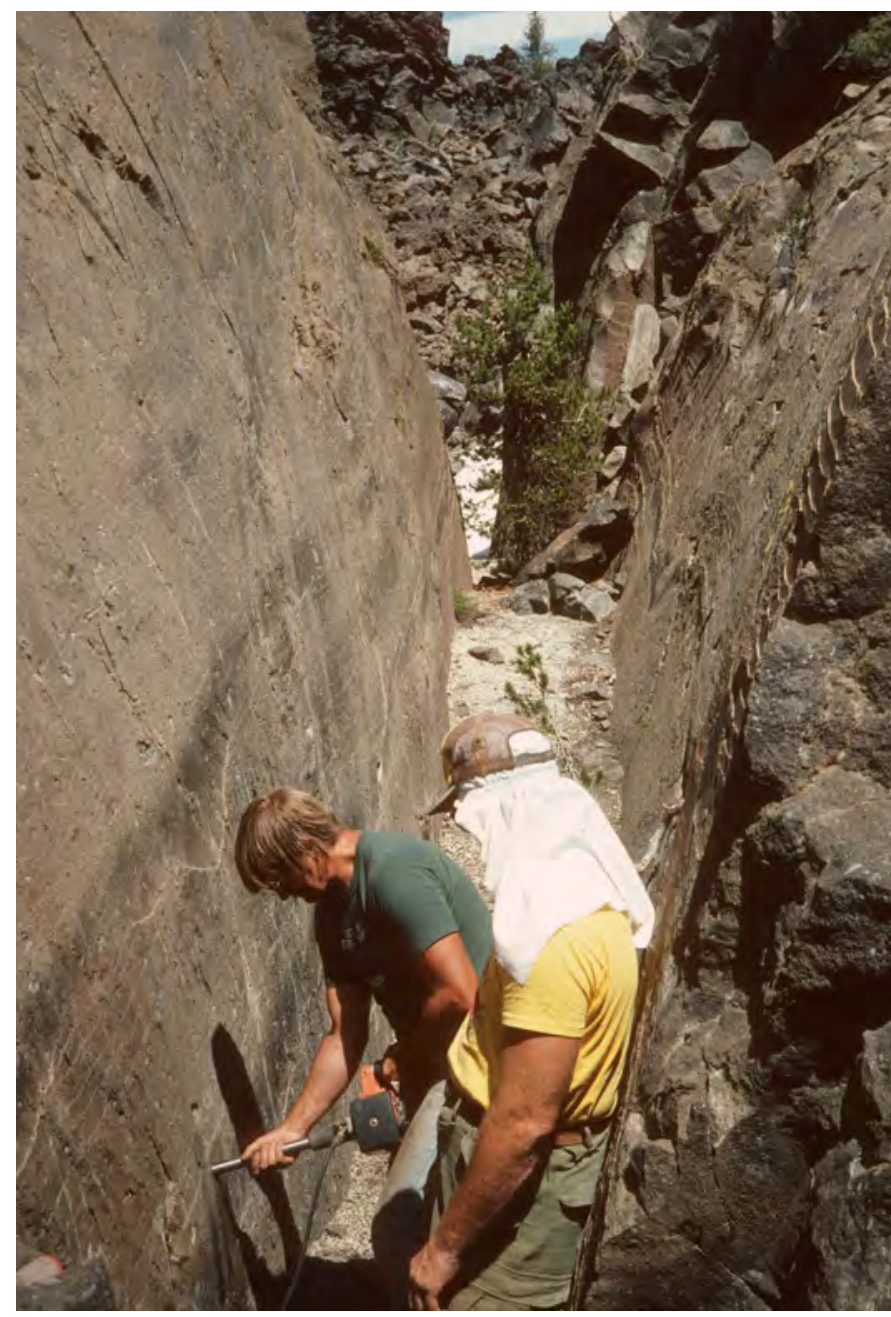

Figure 47. Paleomagnetic drilling in crease structures on the southern of the two Hoffman flows (site 4B456).

\section{Crease Structures}

Crease structures (Anderson and Fink, 1992) are fractured diapiric structures that form when lateral flow advance is restricted and hot, ductile, internal lava is forced upward and outward in a dominantly plastic manner, akin to the more brittle tumuli on basaltic lava flows. An axial crack in the center of the structure is flanked by outwardly curving walls that progressively rotate and separate. These walls can be rough in detail, but smooth compared to the surrounding blocky lava surface (figs. 42 and 47). The angle separating the walls can be as small as 20 degrees (Anderson and Fink, 1992) or as much as 180 degrees where the walls have flattened by continued outward movement.

Crease structures provided opportunities to sample plastic flow morphologies on the tops of silicic lava flows. When available, we sampled crease structures with subparallel walls within 45 degrees of vertical. Sites were selected, when possible, in crease structures with differing orientations, and cores were drilled on both sides of the axial cracks. Sequences of magnetic directions derived through progressive thermal demagnetization of individual samples from opposite sides of the crack were fitted with small circle planes to solve the nature of rotation of each crack. Contrasting crack orientations allowed us to fit mean directions of remanent magnetization to the intersections of planes from different cracks using the method of Kirschvink (1980). In several cases, by way of line fits on vector component diagrams, we were able to derive low temperature PTRM (partial thermal remanent magnetization) acquired after the crack ceased moving, but while it was still hot. In at least two cases (B8490 and 4B368) the crease structure had moved appreciably after cooling, and no reliable plane nor low temperature PTRM line-fit solutions could be derived through thermal demagnetization.

Results with statistically good values (high kappa) were obtained from crease structures on rhyolites of Little Glass Mountain, the Hoffman flows, and the Medicine Lake Glass Flow. Only a few, small crease structures were seen on Glass Mountain, where thermal demagnetization on samples from a single site (B8490) produced only a poorly defined normal polarity. Crease structures where the angle between the walls exceeded 90 degrees are apparently too deformed and were likely too cold by the time of final deformation to appreciably and accurately record the magnetic field.

\section{Near-vent Welded Tephra}

Good results were also obtained from variably welded agglutinate deposits generated by early near-vent tephra falls along both the Glass Mountain fissure (where Anderson [1933] referred to them as pumice cones) and the Little Glass Mountain fissure. Initial tephra that fell close to the vents was hotter and coarser than more distal tephra, allowing variably inflated fragments to stick together (figs. 48 and 49) and sometimes flatten. Most such deposits were found adjacent to the small domes along the Glass Mountain (fig. 49) and Little Glass Mountain rhyolite fissures. All of these sites produced well-grouped magnetic directions.

\section{Quenched Magmatic Inclusions (OMI)}

In one isolated case, quenched magmatic inclusions (QMI) in Glass Mountain obsidian were drilled where they were exposed in the vertical walls of a deep crack within the rhyolite flow (fig. 7 and 50). This 20 -m-deep crack appears to be a crevasse that formed when the front of the rhyolite flow descended down the steep eastern slope of the volcano. The crack apparently opened without producing rotations of the walls when the interior of the flow was still very hot, with hot gases traveling up the crack and oxidizing the exterior surfaces of the broken rhyolitic glass and the QMI. The inclusions were quite crystalline and easily drilled, whereas attempts to drill cores in the surrounding rhyolitic obsidian failed. Results of two sampling trips to this locality, one when much of the crack was filled with snow and enabled drilling high on the walls (fig. 50A, site 4B519), and a second much deeper when most 


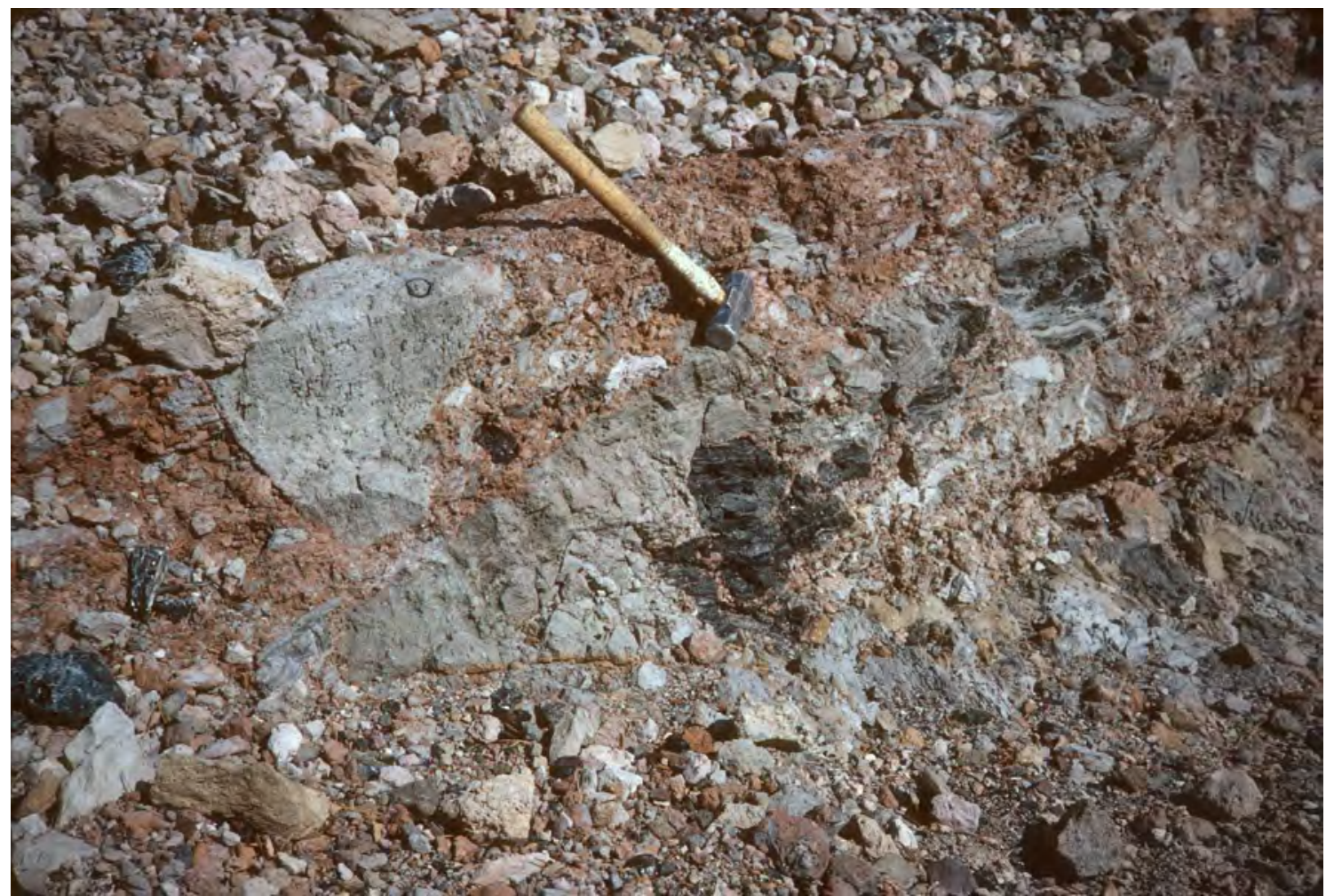

Figure 48. Photograph of welded near-vent agglutinate located adjacent to Glass Mountain dome 3 (site 3B854). A 1-inch-diameter drill core located to left of hammer and not yet removed is a typical example of the dozen cores drilled at each sample site.

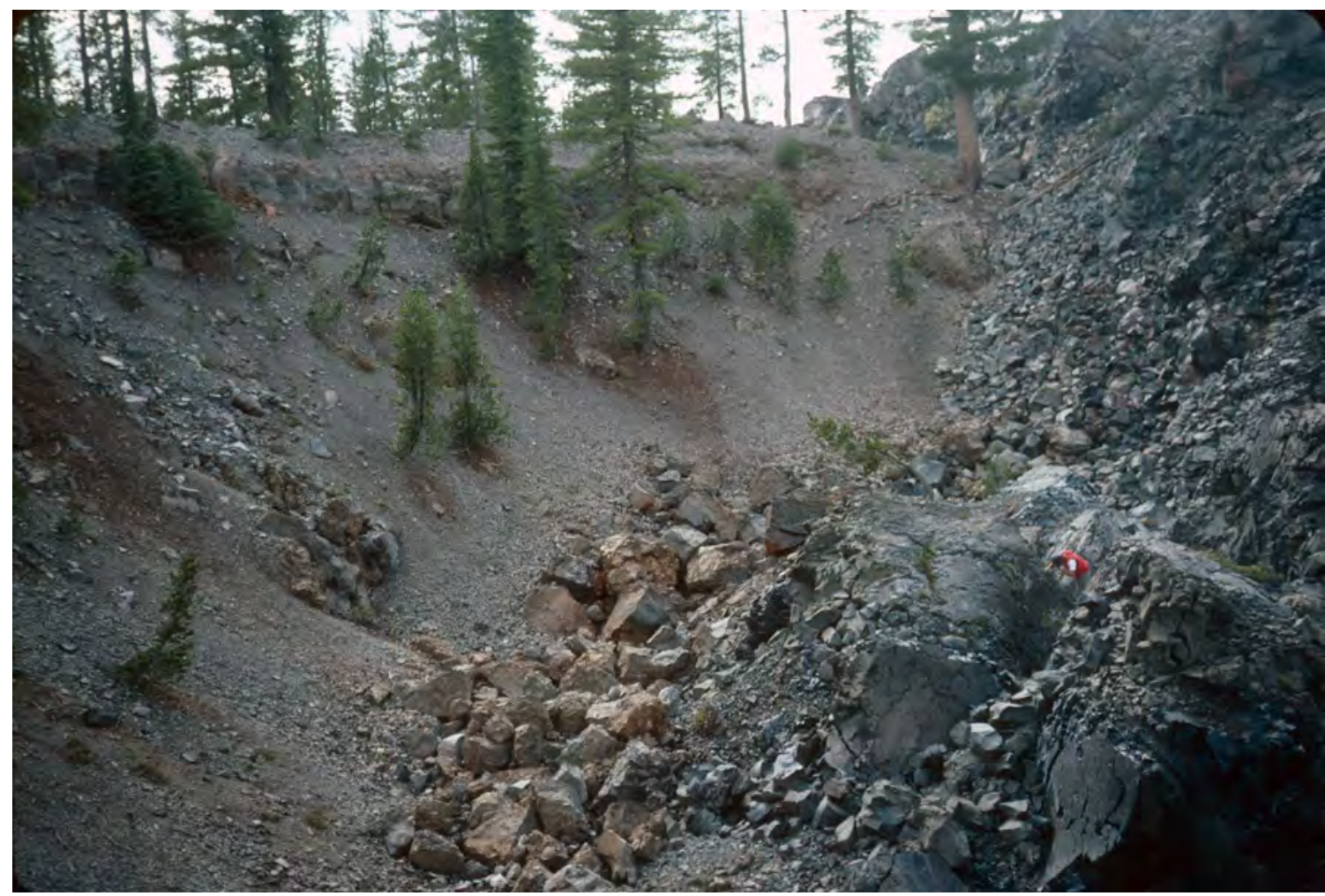

Figure 49. Photograph of drilling in a crease structure on dome 6, the smallest of the Glass Mountain domes. The dome was emplaced into a crater formed by explosion through the initial near-vent welded tephra, which can be seen rimming the crater. Both the dome and the welded tephra were sampled (sites 4B406 and 4B394 in table 3). On the right is dome 7, which has in part flowed south into the dome 6 crater. 

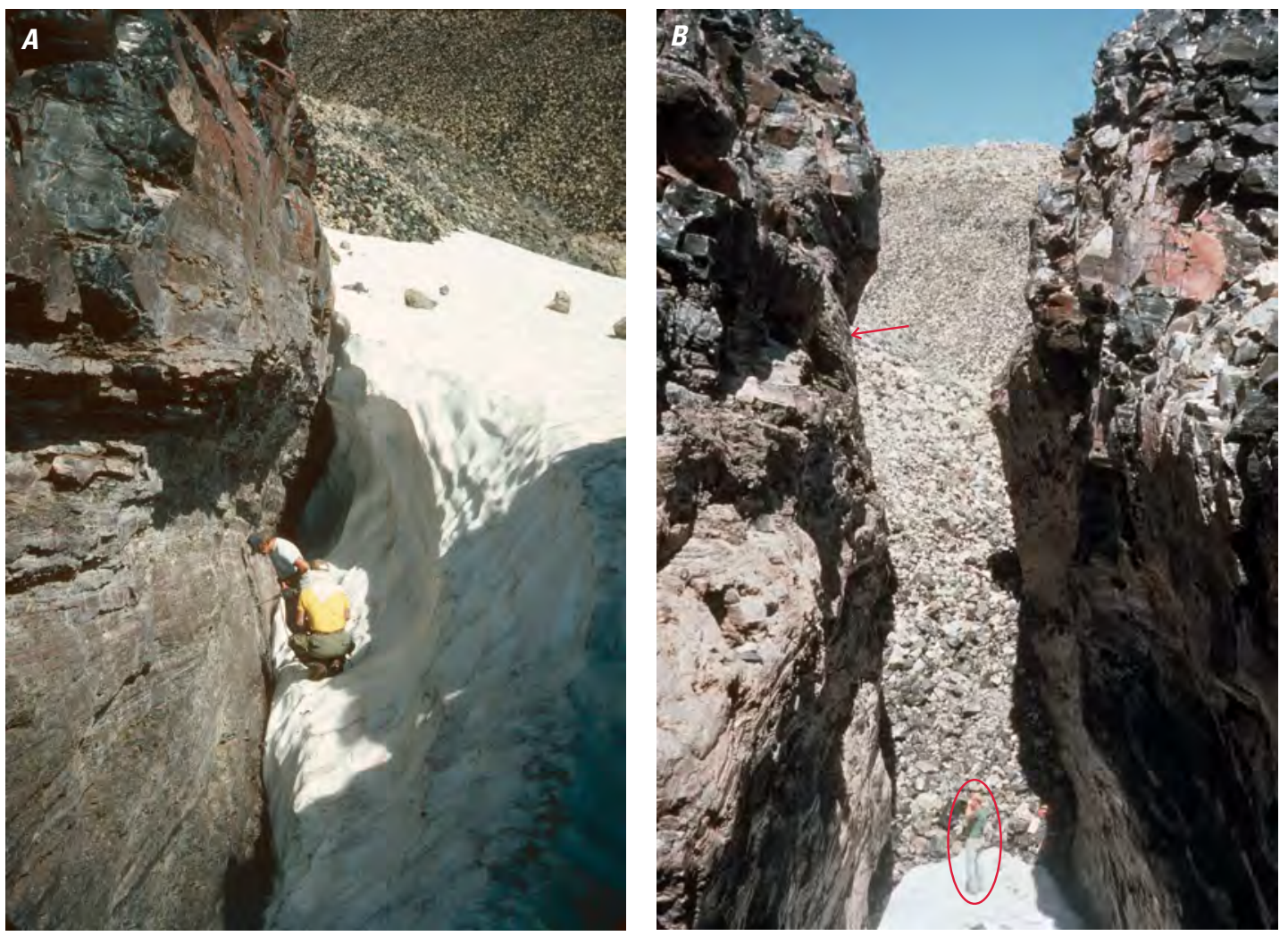

Figure 50. Photographs of paleomagnetic sampling at big crack in the center of the main Glass Mountain flow. This is crack labeled " $C$ " in the aerial view in figure 7. Photo $(A)$ shows the location of the first sampling trip (site 4B519) when the crack was mostly filled with snow; $(B)$ shows the crack on the second trip later in summer when most of snow had melted and samples could be collected low in the crack (site B8478) (photograph by C.D. Miller). Both photos look north. The red arrow pointing to the left wall of the crack in $(B)$ shows the approximate location of sampling site in $(A)$.

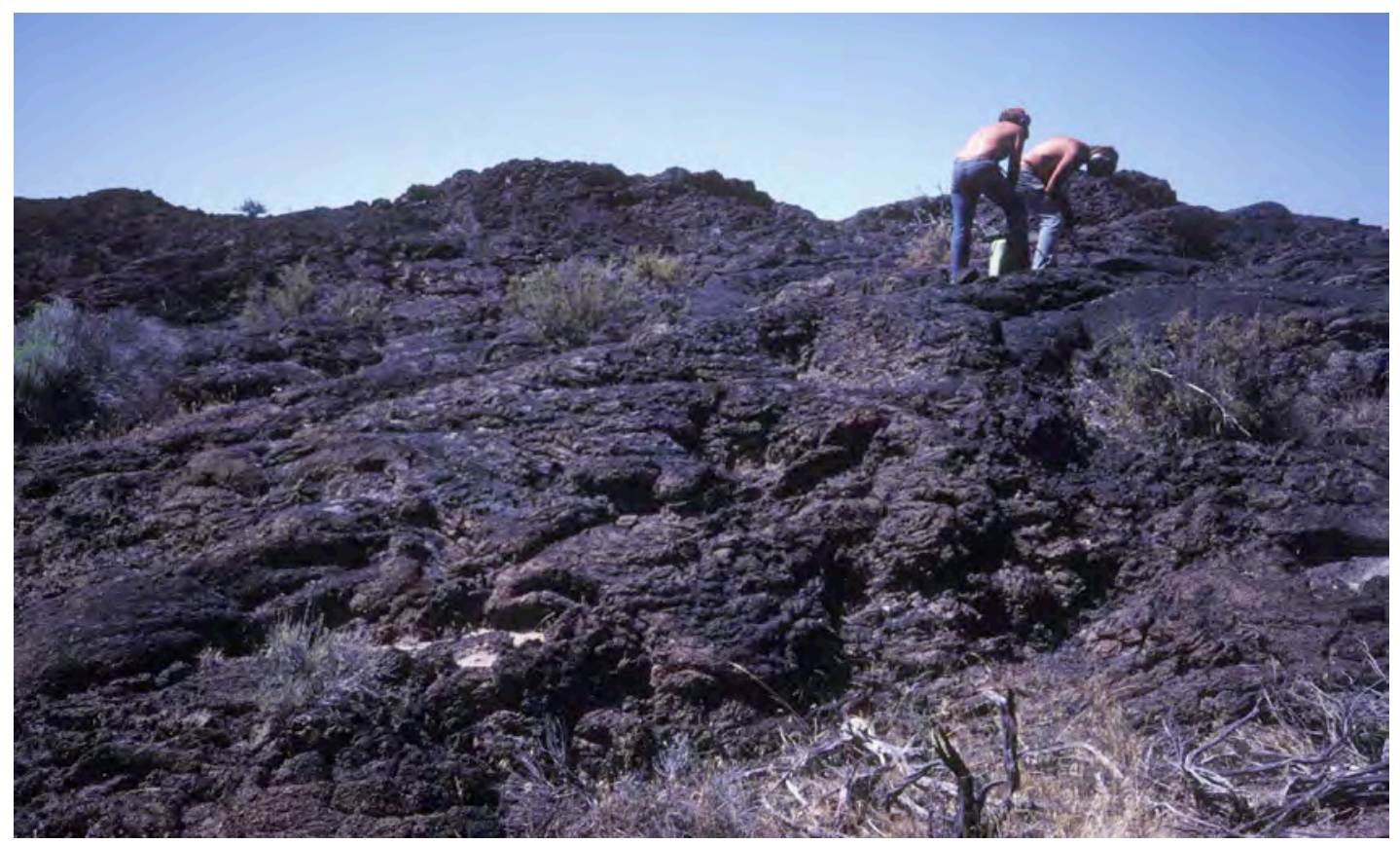

Figure 51. Paleomagnetic drilling at Ross Chimneys in mafic lava showing evidence of fluid morphology. Near-vent spatter flows offer readily sampled material that typically provides well-grouped results. 
of the snow had melted (fig. $50 \mathrm{~B}$, site B8478), are listed in table 3.

\section{Prismatically Jointed Peripheral Blocks}

Blocks displaying radial joints that form intersecting surfaces having the appearance of jigsaw-puzzle pieces can be found at the edges of many of the silicic flows immediately adjacent to steep flow margins. The joints are interpreted as cooling cracks analogous to columnar joints in basalt flows. Intact, but significantly cracked blocks as much as several meters across were interpreted to be hot when they fell off the side of the adjacent flow or dome, with the joints having formed after the block fell. Had the joints existed and blocks been cold when they fell, they would presumably have broken apart along the joints. We identified potential candidate blocks adjacent to both the Little Glass Mountain flow and the Medicine Lake Glass Flow and drilled them following successful application of the method used for Chaos Crags rhyodacite domes at the Lassen Volcanic Center farther south in the Cascades arc (D.E. Champion and M.A. Clynne, unpub. data). However, our results (table 3) were dispersed, suggesting that the sampled blocks had substantially cooled below their Curie temperature before tumbling off the side of the flow.

\section{Lava Levee Environments Including Channel Walls and Shear Planes}

Examples of surfaces exhibiting plastic behavior were found on marginal walls of lava channels that transported dacite of the compositionally zoned Glass Mountain flow. Lava shear zones and adjacent surfaces identified locally within the andesitic Callahan and Burnt Lava Flows also exhibited the morphology of chilled, but plastically deformed surfaces.

The channel walls of Glass Mountain dacite (2B379 and 2B387) yielded initially scattered results, and thermal demagnetization failed to reveal a coherent low temperature PTRM with a single normal polarity direction. Evidently both sites, sampled on opposing levees, were deformed by brittle deformation of the levees during inflation and deflation of the block lava flow. Sites in the more mafic parts of the compositionally zoned Callahan Flow were successfully sampled in deep, railroad cut outcrops (BkFC and 2B266) and at one surface outcrop of late-erupted, less viscous basalt (5B260). Two attempts (7A104 and B8671) to sample the higher silica, more viscous early-eruption parts of that flow produced coherent directional groups, but the directions were not similar to each other, nor to the three closely grouped magnetic directions obtained from sites in more fluid lava. In the latter cases, thermal demagnetization did not reveal an interpretable low temperature PTRM component. Apparently, post-magnetization deformation of lava blocks the size of railroad cars was possible in this flow field.

\section{Spatter Vents and Flow Surfaces in Mafic Lava Flows}

Mafic spatter vents provide environments where fluid magma chills rapidly. Reliable magnetic directions can be recorded even in vesiculated low-density lava materials. Such outcrops were sampled (fig. 51) at Black Crater and Ross Chimneys (sites BkCC and 3A155), at the fissure vent at the northern margin of the Burnt Lava Flow (BrLC), and at the rim of a spatter vent for the Paint Pot Crater flow (2B254). Two large horizontal flow surfaces at Burnt Lava Flow (2B494 and 2B506) also produced well-grouped results. In general these types of outcrops provide the most coherent and reliable sites for field paleomagnetic study of mafic volcanic terranes.

\section{Results of Paleomagnetic Sampling}

Plots showing the paleomagnetic results for each of the nine late Holocene lava flows are shown in figure 52. The locations of sample sites are on figure 46 . Because it is more difficult to sample the silicic lava flows, more sites were necessary to obtain a reliable magnetic direction. Multiple approaches and different kinds of sites were valuable as checks on the accuracy of the results. Paleomagnetic field studies at other volcanoes in the Western U.S. document similar directions of magnetization at these times (Hagstrum and Champion, 2002). Identification of potential sample sites typically involved both examination of aerial photographs, preferably of 1:24,000 scale or better, and field exploration.

A total of eight sites were rejected from consideration because of their scattered or deviant directions of magnetization compared to other sites in the same volcanic units. Of these, six were in rhyolite and dacite block flows, where the stability of outcrops can be easily misjudged. Thermal demagnetization, which can usually detect some low temperature vestige of coherent PTRM magnetizations, failed to reveal a reliable signal from these sites, which are shown in parentheses in table 3.

In a few cases, radiocarbon ages suggested that some of the Holocene volcanic units were of similar age. In other cases, the spatial contiguity, the on-strike or en echelon aspect of vents, chemical compositional similarity, or morphologic appearance also suggested units that might share the same general age. For example, sites in the dacite of Medicine Lake Glass Flow and in the dacite of pit craters, both radiocarbondated at $\sim 5 \mathrm{ka}$, share very similar magnetizations. The same situation exists for the basalt of Black Crater and Ross Chimneys and for the andesite of Burnt Lava Flow, both dated at $\sim 3 \mathrm{ka}$. The similar remanent directions for each of these two cases suggest two episodes of volcanism each enduring only decades or 100-200 years at most (Champion and Shoemaker, 1977). Based on both radiocarbon (Nathenson and others, 2007) and paleomagnetic evidence (fig. 52, table 3), two short periods of activity occurred during the $\sim 1$-ka episode. First, the Hoffman flows erupted, soon followed by the Callahan 

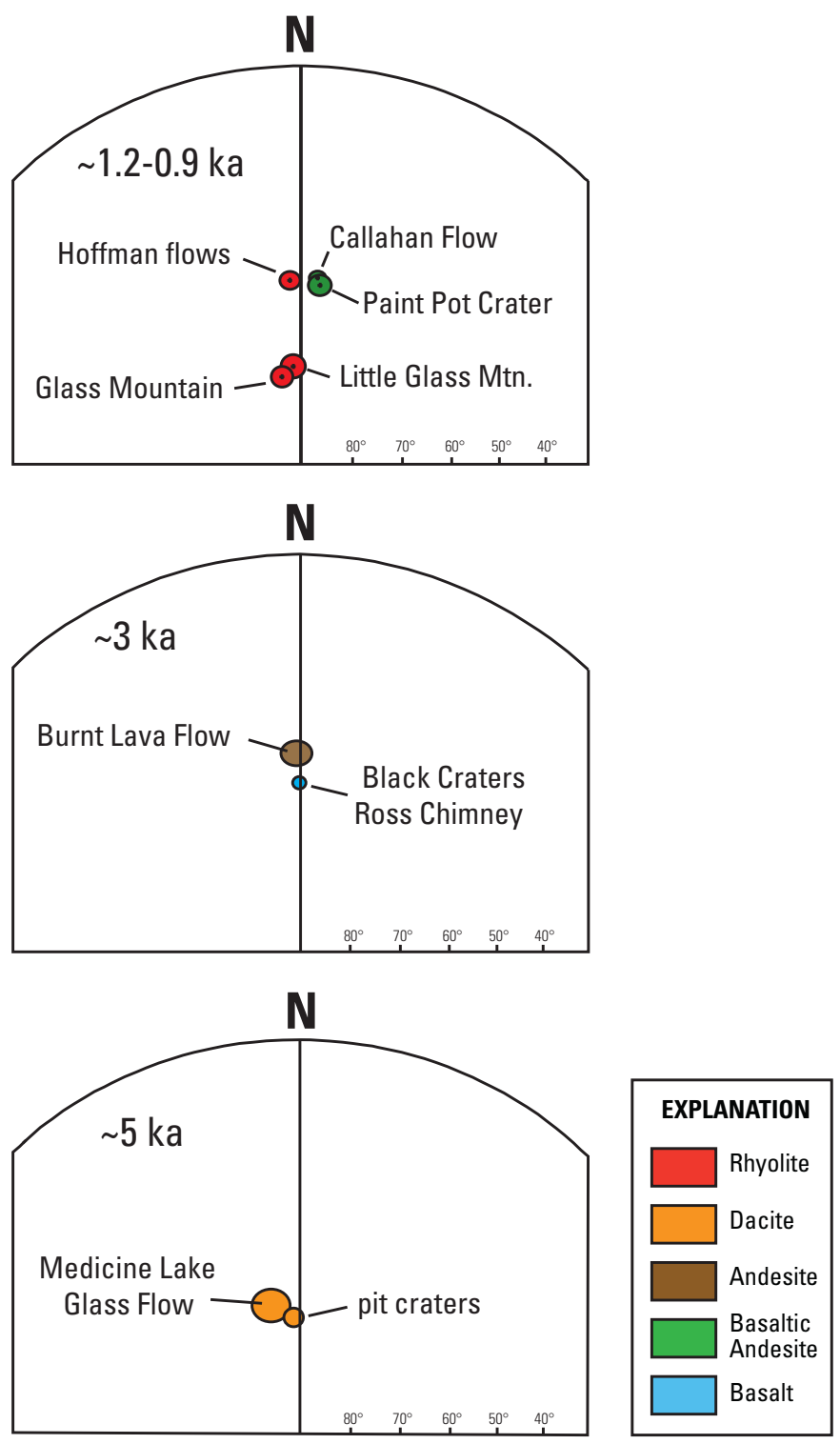

Figure 52. Plots of paleomagnetic directions for late Holocene units grouped by age.

Flow and then the Paint Pot Crater flow between $\sim 1,230$ and 1,170 years ago. After a hiatus of $<200$ years, the Little Glass Mountain and Glass Mountain eruptions occurred $\sim 50$ years apart.

\section{Geophysical Data and Implications}

Geodetic data obtained from leveling, global positioning system surveys, and satellite interferometry at MLV (Dzurisin and others, 1991, 2002; Poland and others, 2006; Parker and others, 2013) indicate relatively rapid subsidence centered on the caldera, with nearly $1 \mathrm{~cm} / \mathrm{yr}$ maximum subsidence since 1954 decaying symmetrically outward over the flanks of the volcano. Ongoing subsidence focused on the central caldera, along with fumarolic activity near Glass Mountain, the presence of an explored geothermal system, and long-period (LP) seismic activity all combine to suggest that the volcano is likely to erupt again.

Two long-period volcanic earthquakes have been recorded at MLV (Pitt and others, 2002). The location of the 1986 event was poorly constrained by the single seismometer in place on the volcano. However, the 1989 event was located at a depth of $15 \mathrm{~km}$ below the western part of the caldera by a temporary array of seismometers installed to monitor a swarm of shallow, brittle failure earthquakes that began under the caldera in 1988. Pitt and others (2002) interpret the LP events as likely related to movement of basaltic magma at depth. It is possible that additional LP events have occurred at the volcano, but were not recorded during lengthy gaps in seismic monitoring.

A low-velocity anomaly was identified under the caldera by a high-resolution active source seismic tomography experiment with 1-2 km resolution (Evans and Zucca, 1998). The authors interpret the anomaly as a small silicic magma chamber no larger than a few tens of cubic kilometers in volume. Using the tomographic data together with seismic refraction data, Chiarabba and others (1995) identified a low-velocity zone at a depth of 3-7 km beneath a cone-shaped highvelocity body in the first $3 \mathrm{~km}$ of the crust. They interpret the high-velocity body as a shallow, subsolidus, intrusive complex that was previously identified by Finn and Williams (1982) using gravity data. The central zone of low velocity is as small as $10 \mathrm{~km}^{3}$ and the authors suggest that it may be a small silicic magma chamber containing partially molten material. Further analysis of teleseismic tomography data (Ritter and Evans, 1997) concluded that no large $\left(>100 \mathrm{~km}^{3}\right)$ silicic magma chamber is present under MLV.

Geothermal drilling at the volcano encountered temperatures in excess of $250{ }^{\circ} \mathrm{C}$ and altered granitoid intrusive rocks $2.5 \mathrm{~km}$ below the eastern caldera floor (Lutz and others, 2000). The study of drill cuttings from another deep drillhole near the center of the caldera indicates that granitoid rocks are present as shallow as $2 \mathrm{~km}$ (Donnelly-Nolan and others, 2008). According to Lutz and others (2000), the geothermal system "... is perhaps the most promising, currently undeveloped, electrical-grade geothermal resource in the contiguous United States." This is despite the near absence of hydrothermal phenomena at the surface. The single active fumarole at the surface is the Hot Spot, located $\sim 2 \mathrm{~km}$ west-northwest of Glass Mountain between the Glass Mountain and Hoffman flows vent fissures.

\section{Magma Sources and Processes}

The large size of MLV, both in area and volume, indicates a major magmatic focus. The broad distribution of vents across the edifice allows for multiple independent pathways to the surface, in contrast to more focally constrained 
stratovolcanoes where homogenization is more likely. Late Holocene eruptions are spread out physically over a large area (fig. 4A,B). Chemically, they include a broad range of compositions from basalt to rhyolite. The opportunity to understand magmatic processes at the volcano is enhanced by the presence of magmatic inclusions captured by individual magma reservoirs prior to eruption.

Comprehensive sampling (table 1) of the compositionally zoned lavas, especially Glass Mountain and the Callahan Flow, as well as collection of numerous magmatic inclusions, combined with detailed petrologic, geochemical, and experimental studies of several units provide information critical to assessing the overall sequence of magmatic and intrusive events and processes at MLV. Compositions of $\sim 5 \mathrm{ka}, \sim 3 \mathrm{ka}$, and $\sim 1$ ka lavas and their included QMI are shown on variation diagrams in figure 5. Some late Holocene lavas and inclusions fall outside the range of earlier MLV lavas (fig. 5). Also, compositions of QMI in Glass Mountain and Little Glass Mountain lavas do not match the compositions found in the late Holocene erupted mafic lavas (fig. 53). The variety of magmatic materials brought to the surface in late Holocene time at MLV is summarized in table 4. Detailed petrologic and geochemical study of the range of lava compositions at MLV (for example, Grove and others, 1988; Grove and others, 1997; Kinzler and others, 2000) has led to a general understanding of parental magma compositions and the processes that have generated the more silicic magmas.

Two types of parental basalt have erupted in late Holocene time, both tholeiitic (dry) and calcalkaline (wet). Among the eight postglacial eruptions that took place at $\sim 12.5 \mathrm{ka}$, all were tholeiitic, notably including the basalt of Giant Crater (Donnelly-Nolan and others, 1991), the most voluminous of the postglacial lavas. Petrologic work (Baker and others, 1991) showed that the more silicic basaltic andesite components of this very large compositionally zoned lava flow were derived from primitive high-alumina olivine tholeiite (HAOT of Hart and others, 1984) by processes of fractionation, assimilation, and mixing. Similar HAOT basalts have intermittently erupted on the flanks of the volcano throughout the history of MLV, but petrologic study of the $\sim 3$ ka Burnt Lava Flow (Grove and others, 1988) showed that combined assimilation and crystallization processes involving dry parental HAOT basalt magmas lead to the production of melts that are only as silicic as andesite.

\section{Late Holocene Mafic Lavas}

In late Holocene time, a variety of erupted and included mafic compositions reached the surface in the $\sim 3 \mathrm{ka}$ and $\sim 1 \mathrm{ka}$ episodes (fig. 53). Basalt similar to HAOT erupted $\sim 3 \mathrm{ka}$ at Black Crater and Ross Chimneys. Analysis of glass inclusions within olivines from Black Crater lava (Sisson and Layne, 1993) yielded very low water content ( 0.1 to 0.3 weight percent) similar to mid-ocean ridge basalts. However, elevated $\mathrm{K}_{2} \mathrm{O}, \mathrm{TiO}_{2}$, and $\mathrm{P}_{2} \mathrm{O}_{5}$ contents in a subset of the glass inclusions led the authors to suggest a qualitative similarity to the combined effects of shallow tholeiitic differentiation and assimilation of granite, akin to the explanation (Grove and others, 1988) for the chemical characteristics of the andesite of Burnt Lava Flow. The Burnt Lava Flow is distinctive in preserving both primitive HAOT-type QMI and partially melted granitic inclusions. The model proposed by Grove and others (1988) for the origin of this andesite flow involves initial intrusions of HAOT melt into the crust, followed by multiple replenishments of the same type of primitive basalt along with dry (nearly anhydrous) fractional crystallization of the basalt and melting of crust with the heat of crystallization. The assimilation process occurs when replenishment of primitive HAOT magma triggers mixing of the melted crust with residual iron-rich liquids produced by fractional crystallization. The preservation of the primitive basalt QMI in the andesite host indicates that a final intrusion of basalt mingled with the andesitic magma just prior to or during eruption. Oxygen isotope data for the basaltic QMI in the $\sim 3 \mathrm{ka}$ Burnt Lava Flow and in the Hoffman flows have $\delta^{18} \mathrm{O}$ values from +5.8 to +6.1 per mil, compatible with an origin as mantlederived basalt (Donnelly-Nolan, 1998).

By contrast with the dry tholeiitic inputs recorded in the $\sim 12.5 \mathrm{ka}$ and $\sim 3 \mathrm{ka}$ eruptions, mafic lavas that erupted at the surface during the $\sim 1$ ka episode show a wet calcalkaline signature. Kinzler and others (2000) identified a hydrous signature within the Paint Pot Crater flow when they found amphibole-bearing melt inclusions within olivine phenocrysts, together with calcic plagioclase indicative of 3 to 6 weight percent $\mathrm{H}_{2} \mathrm{O}$ based on plagioclase-melt equilibria. In addition to this evidence for water, Kinzler and others (2000) used the results of experimental petrology combined with geochemistry and isotopic data to show that both the Paint Pot and Callahan flows have calcalkaline arc-type signatures indicating a significant role for water in the generation of the basaltic parental magmas. The estimated water content for parent melts of Paint Pot and Callahan flows is 3 to 6 weight percent.

\section{Late Holocene Silicic Lavas}

The earliest of the late Holocene silicic lavas, the $\sim 5-\mathrm{ka}$ dacites that erupted in the caldera, show evidence of calcalkaline basalt parentage. The presence of amphibole-bearing andesitic inclusions in the Medicine Lake Glass Flow indicates that high water content was involved in production of the andesitic melt (Grove and others, 1997; Kinzler and others, 2000). The abundance of wet basaltic melt erupted and intruded at MLV in late Holocene time, and apparently intruded pre-5-ka, likely facilitated melting of geophysically identified subjacent older granitic crust beneath the volcano. This process helped to generate significant amounts of silicic lava that erupted in larger volumes and with significantly higher silica contents than at any time at MLV since $\sim 300 \mathrm{ka}$ (Donnelly-Nolan and others, 2008). Petrologic work by Kinzler and others (2000) showed that when combined with 

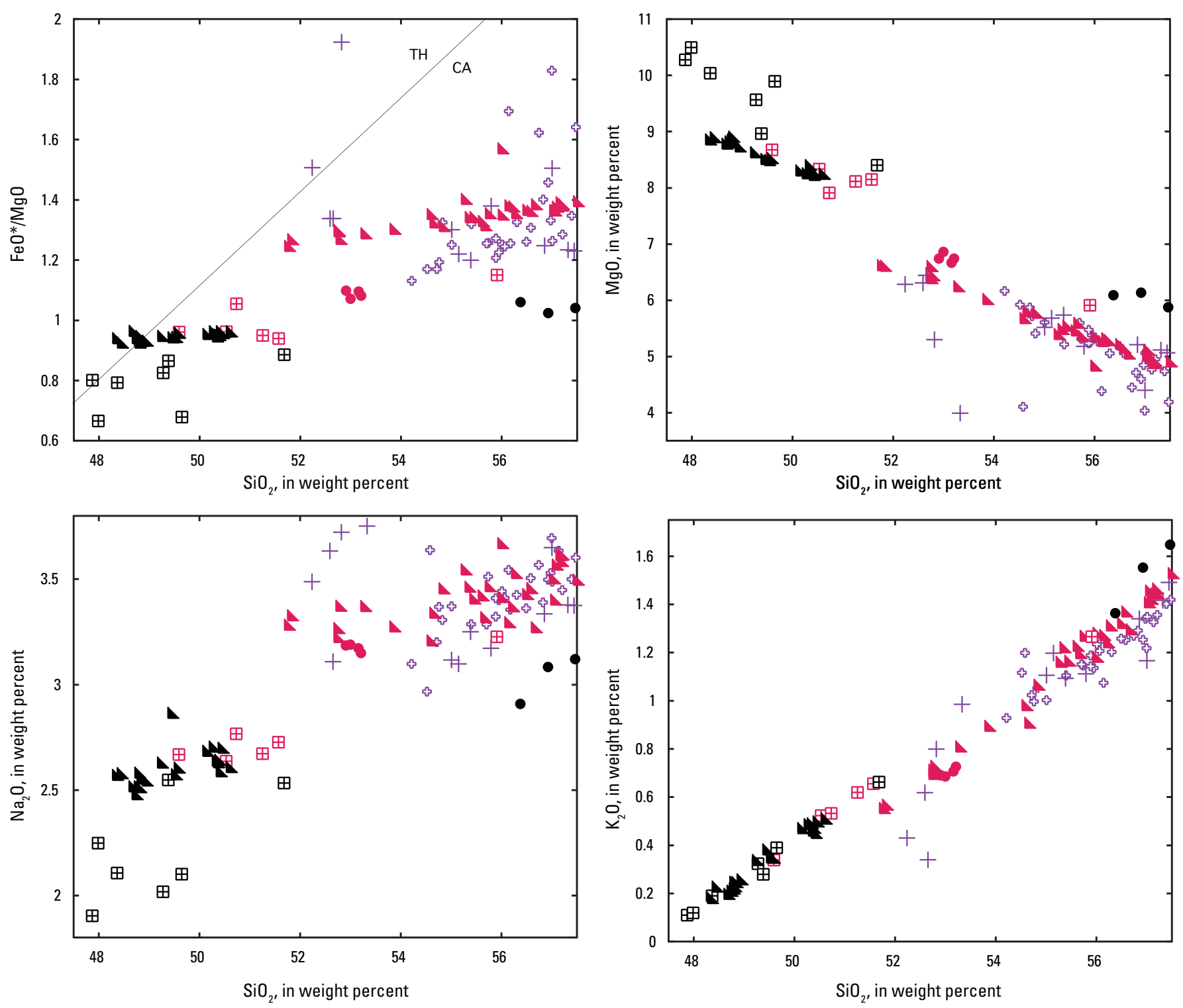

\begin{tabular}{|c|c|c|}
\hline \multicolumn{3}{|c|}{ EXPLANATION } \\
\hline 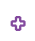 & rgm QMI & \\
\hline+ & $\mathrm{rlg}$ OMI & \\
\hline - & mpp & $\sim 1 \mathrm{ka}$ \\
\hline$\Delta$ & $\mathrm{mcf}$ & \\
\hline 田 & rh QMI & \\
\hline 田 & abl & \\
\hline$\bullet$ & abl QMI & $\sim 3 \mathrm{ka}$ \\
\hline $\mathbf{\Delta}$ & $\mathrm{bbr}$ & \\
\hline
\end{tabular}

Figure 53. Silica variation diagrams showing compositions of mafic lavas and quenched magmatic inclusions (QMI) erupted in late Holocene time. Symbols in purple and red for $\sim 1-k a$ eruptions; symbols in black for 3-ka eruptions. Unit symbols are from Donnelly-Nolan (2010); rhyolite of Glass Mountain, rgm; rhyolite of Little Glass Mountain, rlg; basaltic andesite of Paint Pot Crater, mpp; basaltic andesite of Callahan Flow, mcf; rhyolite of Hoffman flows, rh; andesite of Burnt Lava Flow, abl; basalt of Black Crater and Ross Chimneys, bbr. No analyzed 5-ka quenched magmatic inclusions are this mafic. Black line separates fields designated as tholeiitic (TH) and calcalkaline (CA) by Miyashiro (1974). 

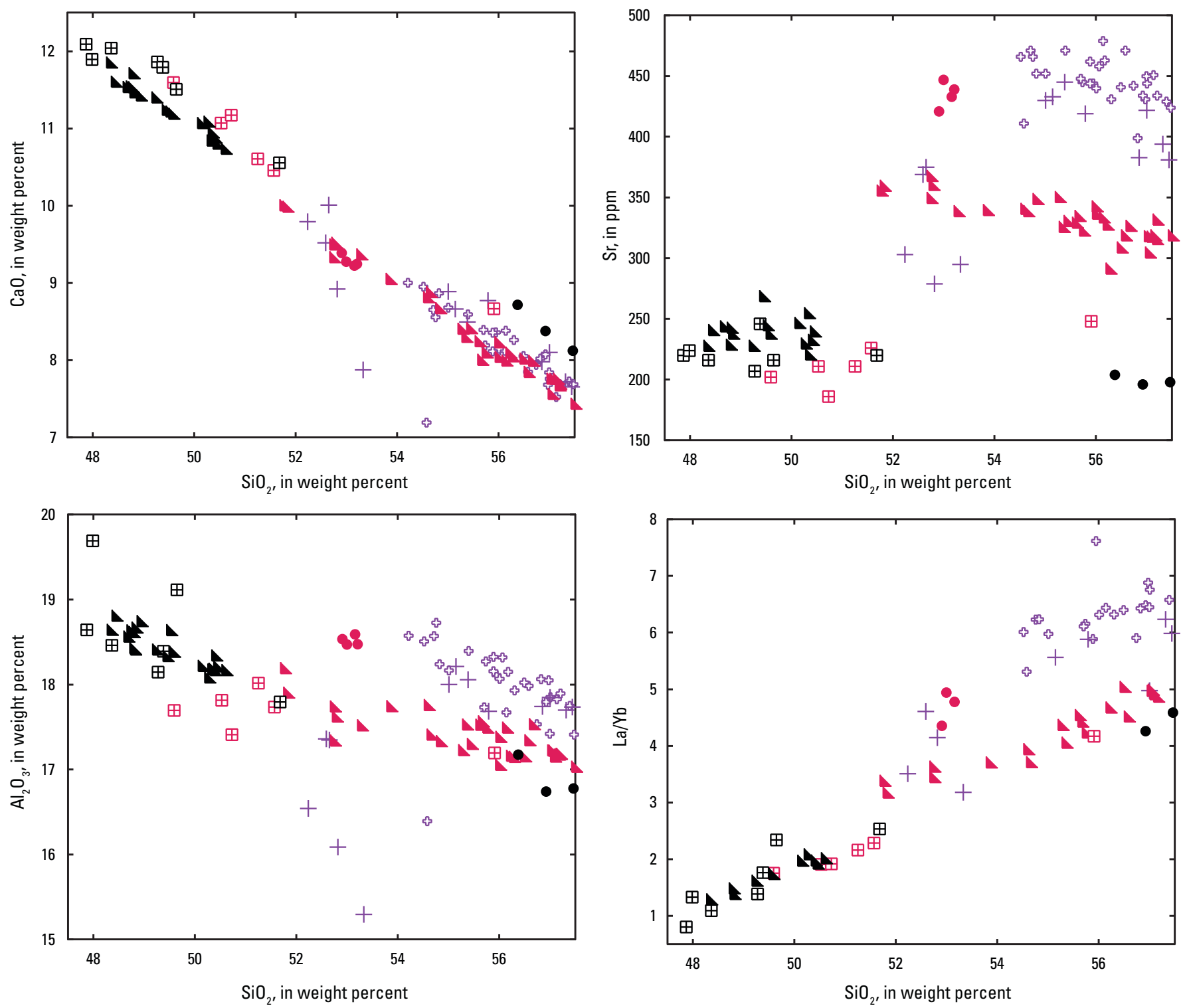

Figure 53.-Continued 


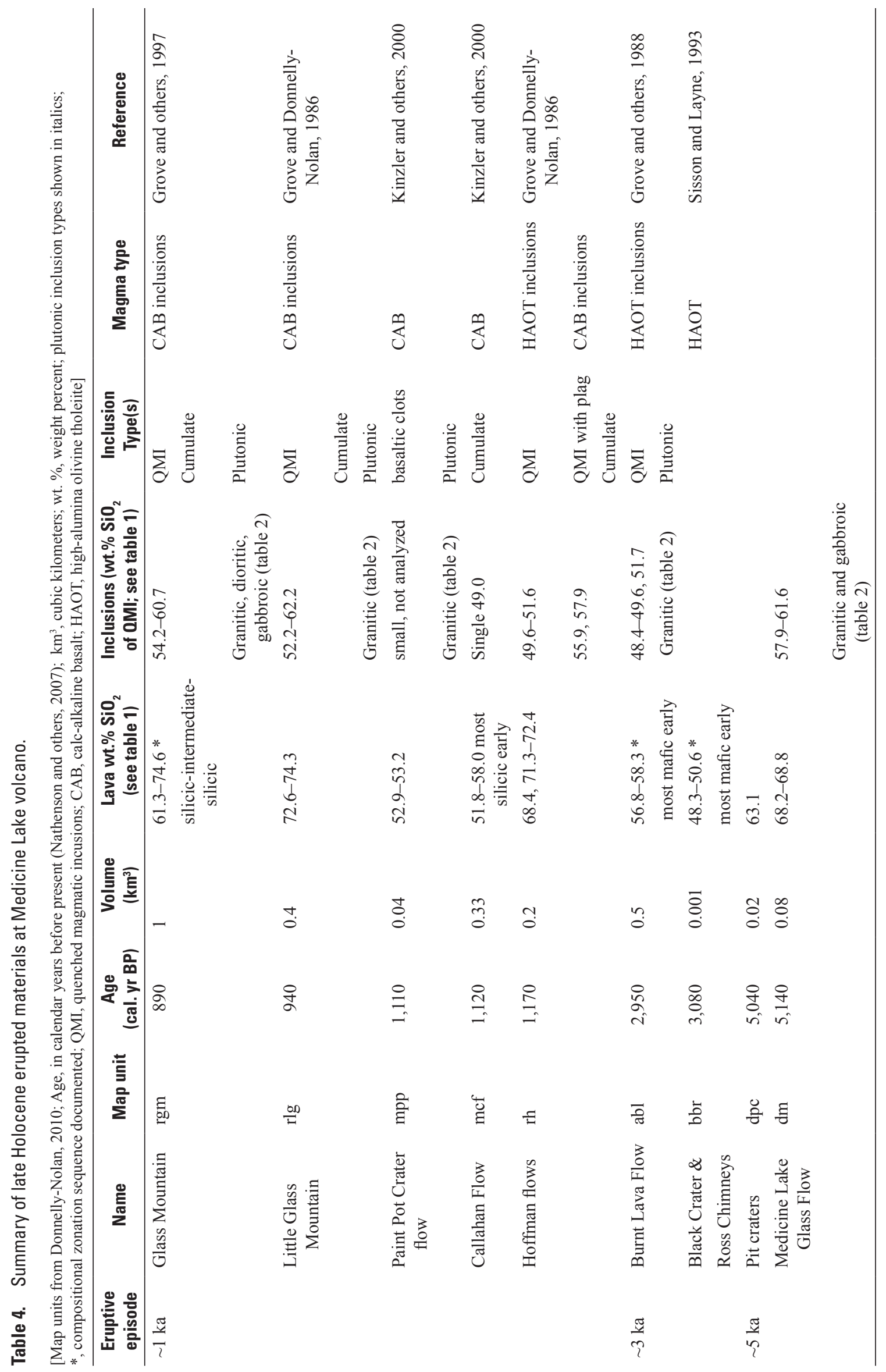




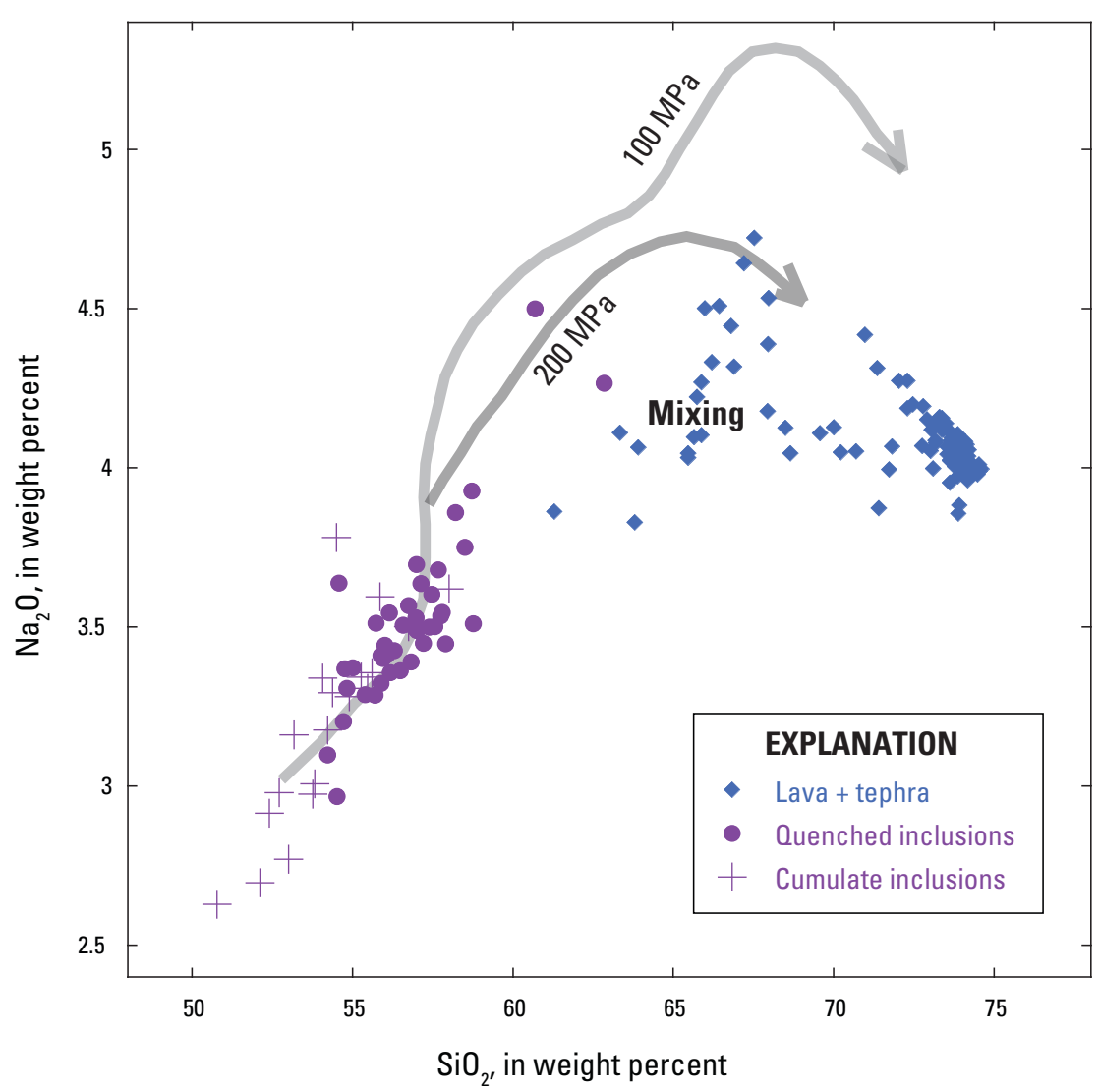

Figure 54. Plot showing experimentally determined compositional paths (gray lines) compared to the actual Glass Mountain compositions. Experimental pressures indicate depths of 3-6 km for the fractionation and assimilation that occurred to create the Glass Mountain magmatic products. Details of the study are in Grove and others (1997).

melting and assimilation of granitic crust, fractional crystallization processes involving wet calcalkaline basalt can lead to the production of significant amounts of rhyolite. The presence of hydrous calcalkaline mafic lavas at MLV indicates that subduction-related processes (for example, slab fluids) operated to generate magmas like those erupted in late Holocene time.

High $\delta^{18} \mathrm{O}$ values $(+7.5$ to +8.5$)$ in the two $\sim 5$-ka calderacentric dacites indicate large contributions of crustal material such as the granitic inclusions found in the Medicine Lake Glass Flow (Donnelly-Nolan, 1998). The latest Holocene rhyolites, those erupted during the $\sim 1$ ka episode, all have elevated $\delta^{18} \mathrm{O}$ values, also indicating incorporation of crustal material. No granitic inclusions were found in the oldest of these flows, the Hoffman flows, although they were found in the younger Little Glass Mountain and Glass Mountain lavas. The Hoffman flows are distinctive in being the only rhyolitic lava flows containing basaltic QMI with compositions and low $\delta^{18} \mathrm{O}$ values similar to the HAOT erupted at Giant Crater, the $\sim 3$-ka Black Crater and Ross Chimneys, and as QMI in the $\sim 3$-ka Burnt Lava Flow. The Glass Mountain eruption took place less than 300 years after the Hoffman flows on a nearby parallel fissure, but contains instead wet calcalkaline andesitic QMI, many of which crystallized hornblende. Little Glass Mountain, slightly older than Glass Mountain and $16 \mathrm{~km}$ to the west, also has hornblende-bearing inclusions, although none of the host rhyolite lavas have crystallized this mineral. The variety of included materials produced by the Glass Mountain and Little Glass Mountain eruptions indicate complex magmatic histories involving several episodes of mafic magma injection. Petrologic study of the Glass Mountain system (Grove and others, 1997) included experimental work indicating fractional crystallization of an $\mathrm{H}_{2} \mathrm{O}$-rich andesitic parent magma at pressures of 100 to $200 \mathrm{MPa}$. Experimentally determined liquid lines of descent are shown at two pressures on an $\mathrm{SiO}_{2}-\mathrm{Na}_{2} \mathrm{O}$ plot (fig. 54). The experimental petrology together with geochemistry and isotopic data indicate that assimilation of significant volumes of granitic crustal material was also important in generating the rhyolitic magma. The Glass Mountain dacite is a mixture of variously evolved rhyolitic melts produced by fractionation of intruded parental mafic andesite, combined with a granitic crustal melt, and mixed with a more mafic andesitic melt (Grove and others, 1997). The dacite is charged with andesitic QMI, some of which may have been incorporated immediately prior to eruption.

The three late Holocene rhyolite eruptions that occurred during the $\sim 1$-ka episode took place on fissures tangent to the west and east sides of the caldera. Heiken (1978) suggested that the Glass Mountain and Little Glass Mountain rhyolites 

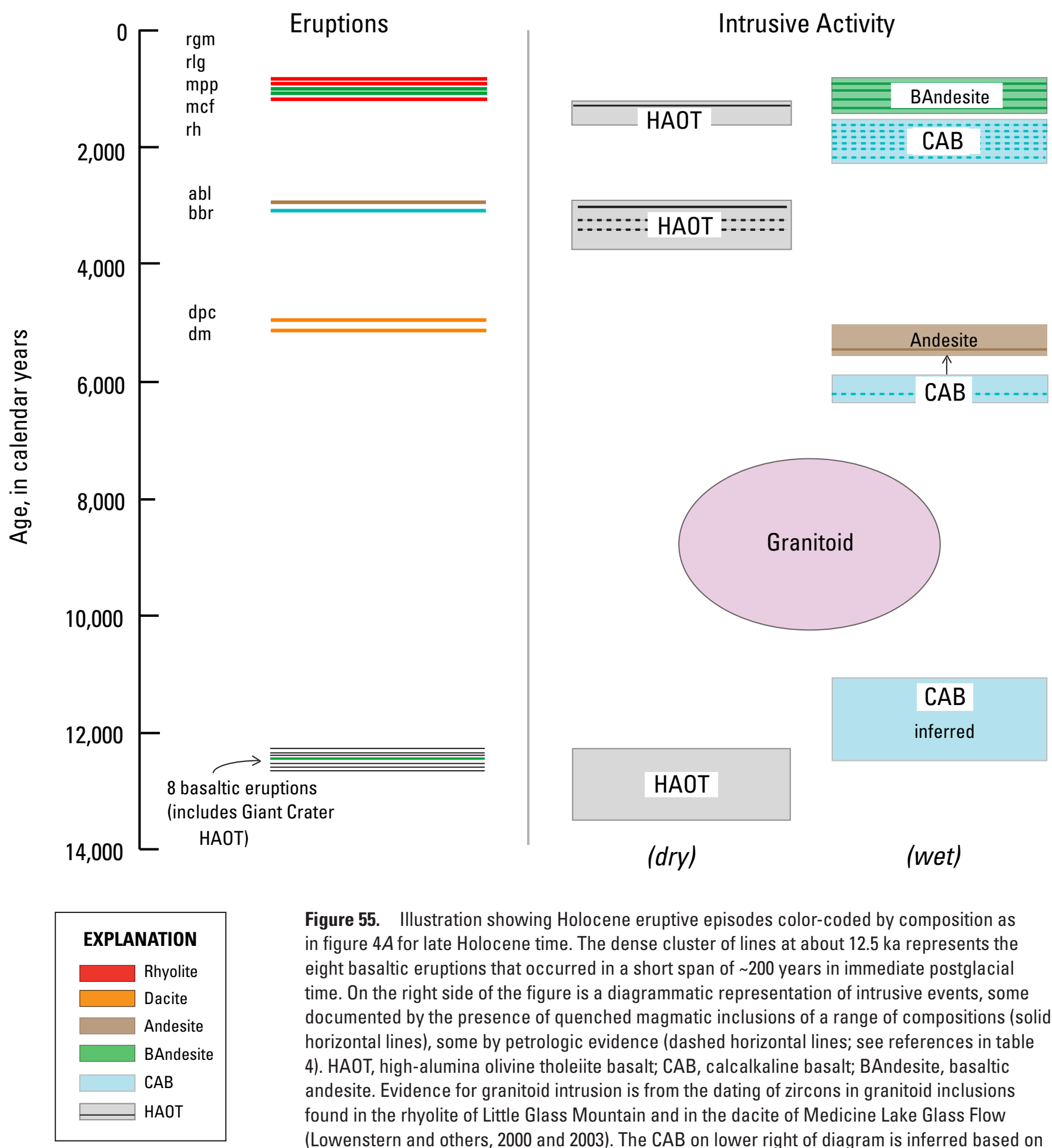

Figure 55. Illustration showing Holocene eruptive episodes color-coded by composition as in figure $4 A$ for late Holocene time. The dense cluster of lines at about 12.5 ka represents the eight basaltic eruptions that occurred in a short span of 200 years in immediate postglacial time. On the right side of the figure is a diagrammatic representation of intrusive events, some documented by the presence of quenched magmatic inclusions of a range of compositions (solid horizontal lines), some by petrologic evidence (dashed horizontal lines; see references in table 4). HAOT, high-alumina olivine tholeiite basalt; $C A B$, calcalkaline basalt; BAndesite, basaltic andesite. Evidence for granitoid intrusion is from the dating of zircons in granitoid inclusions found in the rhyolite of Little Glass Mountain and in the dacite of Medicine Lake Glass Flow (Lowenstern and others, 2000 and 2003). The CAB on lower right of diagram is inferred based on the petrologic and geochemical arguments of Kinzler and others (2000) that wet (calcalkaline) magmas differentiate to produce silicic melts, whereas dry (HAOT) magmas can differentiate only to andesite. 
were fed by cone sheets (arcuate dikes) from a small magma body under the caldera. Eichelberger (1981) suggested instead that a single large magma body that stretched beyond the 12-km east-west extent of the caldera fed both eruptions. Donnelly-Nolan (1988) argued for a model of multiple small magma bodies under the volcano. Geophysical data (Evans and Zucca, 1998) support the current presence of a small magma body, but the configuration of magma reservoirs 1,000 years ago is unknown. Petrography and inclusions indicate some differences between the two youngest rhyolitic eruptions. We suggest that rather than both Glass Mountain and Little Glass Mountain rhyolites being fed by a single magma body, a more likely explanation of the similarity in rhyolite composition reflects the similarity of the calcalkaline parental magmas from which they were derived, and the magmatic processes that operated on both the west and east sides of the caldera.

\section{Episodic Eruptive Activity and Tectonics}

The abundance and variety of erupted and included magmatic materials combined with petrologic evidence for multiple wet and dry parental magmas provides a rich record documenting an active magmatic system that is likely to erupt again. In figure 55 we depict the nine eruptive events and the apparent timing and types of intrusive events. At least seven intrusive events are directly indicated by the variety of QMI in the erupted lavas. Intrusions are also inferred based on petrologic evidence for multiple inputs of mafic magma, notably in the generation of the Burnt Lava, Callahan, Little Glass Mountain, and Glass Mountain magmas. Because the host lavas for the QMI are poorly porphyritic and the inclusions commonly display textures indicating rapid cooling, we conclude that lengthy subjacent storage prior to eruption is unlikely. A plausible combined total of at least 25 intrusive and extrusive events is indicated, or approximately one every 170 years on average between 5,200 years ago (eruption of Medicine Lake Glass Flow) and 950 years ago (eruption of Glass Mountain). This is likely a minimum estimate of the total number of magmatic events. There is no evidence for intrusive activity since the Glass Mountain eruption, but neither can it be ruled out.

A fundamental characteristic of MLV is the interaction of tectonism and volcanism (Donnelly-Nolan and others, 2008) and it is likely that the episodic eruptive behavior of the volcano is controlled by tectonic forces. All of the late Holocene lavas were erupted from multiple vents (figs. 3 and 4) and eight of the nine were clearly fissure-fed. The linear vent arrays also imply that emplacement of dikes is a major process at MLV. Vents for the $\sim 3$-ka mafic eruptions are separated by a north-south distance of $27 \mathrm{~km}$, but because both involved similar basaltic magma, the timing suggests that they could be related to a single diking event. All late Holocene units except the caldera-bound Medicine Lake Glass Flow erupted from vents aligned within $40^{\circ}$ of north. More than half have alignments within $25^{\circ}$ of north, strongly reflecting tectonic control
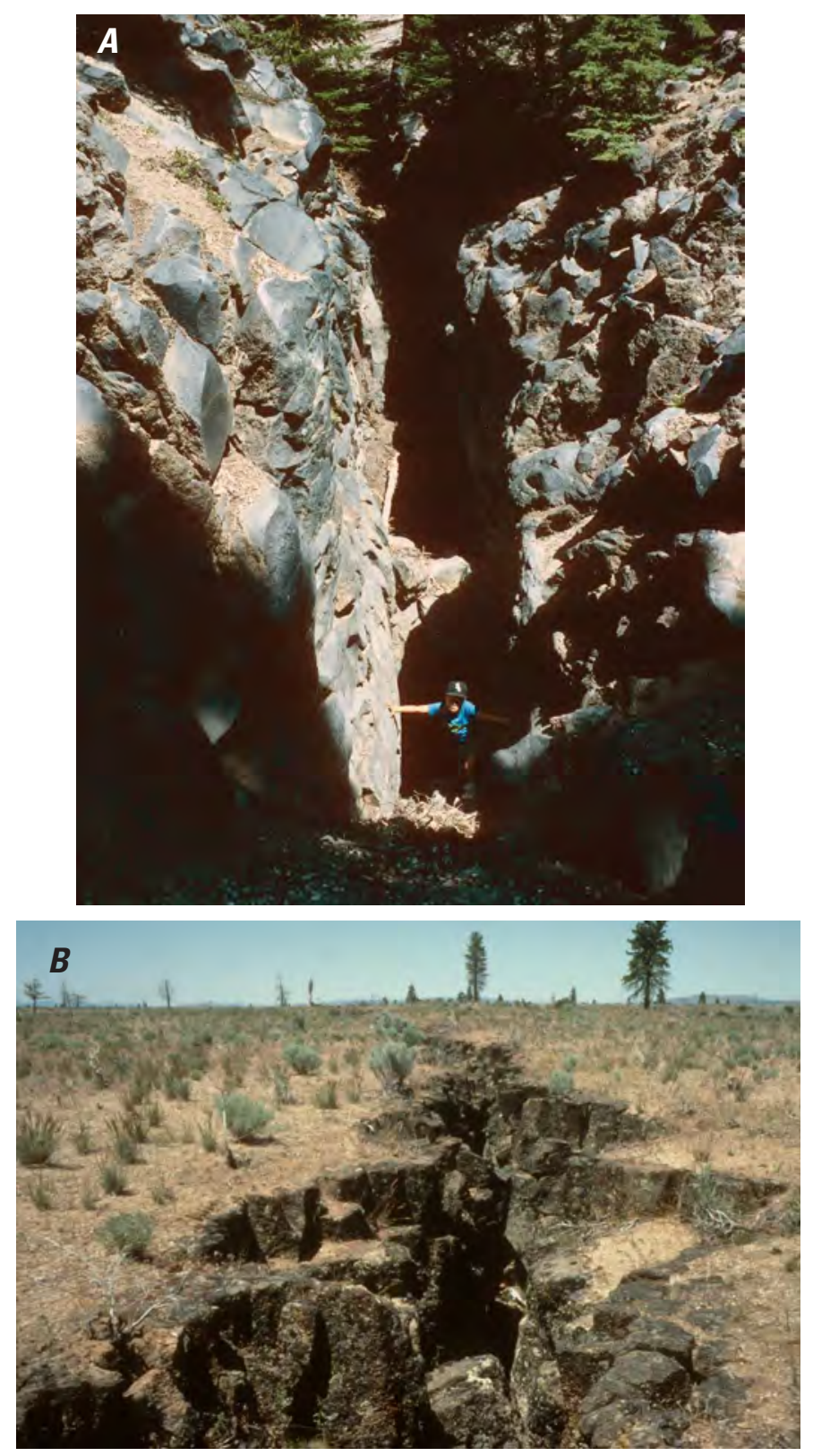

Figure 56. Photographs showing examples of numerous open cracks at Medicine Lake volcano. $(A)$ Crack on the main edifice at the northeastern extent of the dacite of pit craters fissure (child for scale); $(B)$ on lower east flank in Pleistocene basalt (graygreen sagebrush plants $\sim 0.5 \mathrm{~m}$ high for scale), both reflecting the overall east-west tectonic regime.

by the east-west regional extensional environment (DonnellyNolan and others, 2008), which is also shown by faults on and adjacent to the volcano that display northwest to northeast trends (fig. 3). Faulting includes vertical offset of the $\sim 12.5$-ka basalt of Giant Crater by $\sim 10 \mathrm{~m}$ (fig. 6 in Donnelly-Nolan and others, 2007), multiple open cracks (fig. 26) that formed during the Little Glass Mountain eruption (Fink and Pollard, 1983), and the many north-to northeast-trending open cracks (fig. 56) found scattered around the north and east flanks of the volcano. 


\section{Conclusions}

The nine compositionally diverse eruptions that took place at the $>2,000-\mathrm{km}^{2}$ Medicine Lake volcano since $\sim 5 \mathrm{ka}$ constitute one of the most frequent late Holocene eruptive records at a Cascades arc volcano. The eruptions are spread over an area of $\sim 300 \mathrm{~km}^{2}$, an area about twice the footprint of the Mt. St. Helens edifice. The diversity of erupted compositions from basalt to rhyolite in such a short interval of time is remarkable. Application of a variety of methods including geologic mapping and stratigraphy, geochemistry, paleomagnetism, radiocarbon dating, and experimental petrology has illuminated one of the best-understood records of late Holocene magmatic activity in the Cascades arc. Evidence from paleomagnetism and radiocarbon dating strongly indicate that the eruptive activity actually occurred in episodes. An episode of two caldera-centric dacitic eruptions separated by $\sim 100$ years took place at the volcano's summit caldera at $\sim 5 \mathrm{ka}$. At $\sim 3 \mathrm{ka}$, an eruption of basalt and another of andesite took place on the north and south sides of MLV, respectively, within a period of $<200$ years. After another two millenia of quiescence, five eruptions took place within a period of $<300$ years beginning at $\sim 1.2 \mathrm{ka}$, including the largest and youngest Holocene rhyolite flow in the Cascades volcanic arc, the spectacular 950-yr-old Glass Mountain lava flow.

In addition to the documented eruptive record, evidence for intrusive events is preserved as quenched magmatic inclusions (QMI) in five of the nine erupted lavas and as compositional zoning in four eruptions. Petrologic work provides critical evidence that multiple magmatic recharge events are required to generate the erupted lavas. A total of at least 20 intrusive and extrusive events occurred, giving an overall average rate of one magmatic event every 250 years.

Medicine Lake volcano lies in an extensional environment east of the main arc axis where the Basin and Range Province impinges on the Cascades arc. Well-defined northeast- to northwest-trending vent alignments and documented fissure eruptions indicate the strong interaction of tectonism and volcanism. Both dry tholeiitic basalt typical of the westernmost Basin and Range (HAOT of Hart and others, 1984) and wet arc-type calcalkaline basalt have erupted at MLV in late Holocene time as documented by experimental, mineralogical, and geochemical data from several petrologic studies. The QMI can also be characterized as being of dry or wet origin based on composition and mineralogy. The chronology of the erupted host lavas indicates that wet parental magma was present under the caldera at $\sim 5 \mathrm{ka}$, as represented by amphibole-bearing andesitic inclusions in the Medicine Lake Glass Flow. At $\sim 3$ ka, dry HAOT-type melts both intruded and erupted on the north and south sides of the volcano. Basalt similar to HAOT is also present as inclusions in the $\sim 1.2$-ka rhyolite eruption on the eastern side of the caldera, but was soon followed by the eruption to the west and north of the caldera of two mafic lavas petrologically shown to have calcalkaline arc-type basalt parents. Hornblende-bearing mafic magmatic inclusions in the two youngest eruptions, the caldera-bracketing fissure rhyolites of $\sim 1,000$-yr-old Little Glass Mountain and the $\sim 950$-yr-old Glass Mountain were also derived from calcalkaline parental basalts. The QMI in these rhyolites are geochemically distinct from any of the erupted mafic lavas. The abundance of wet basaltic melt erupted and intruded at MLV in late Holocene time likely facilitated melting of granitic crust beneath the volcano, helping to generate the significant amounts of silicic lava that erupted in late Holocene time.

Evidence including the frequency of eruptive and intrusive magmatic activity in late Holocene time, geophysical documentation for active deformation, the presence of a high-temperature geothermal system, and the occurrence of intermittent long-period earthquakes all combine to indicate that MLV is still restless and will likely erupt again.

\section{Acknowledgments}

We are grateful to the many field assistants and students who helped in the field. Reviews by Michelle Coombs and Heather Wright are gratefully acknowledged. National Science Foundation Grants EAR-0073766, EAR-0440172, EAR0538179, and EAR-118598 supported the participation of TLG in this work.

\section{References}

Anderson, C.A., 1933, Volcanic history of Glass Mountain, northern California: American Journal of Science, v. 26, p. $485-506$.

Anderson, C.A., 1941, Volcanoes of the Medicine Lake Highland, California: University of California Publications, Bulletin of the Department of Geological Sciences, v. 25, no. 7 , p. 347-422.

Anderson, S.W., and Fink, J.H., 1992, Crease structuresIndicators of emplacement rates and surface stress regimes of lava flows: Geological Society of America Bulletin, v. 104, p. 615-625.

Bacon, C.R., 1986, Magmatic inclusions in silicic and intermediate volcanic rocks: Journal of Geophysical Research, v. 91, no. B6, p. 6091-6112.

Baker, M.B., Grove, T.L., Kinzler, R.J., Donnelly-Nolan, J.M., and Wandless, G.A., 1991, Origin of compositional zonation (high-alumina basalt to basaltic andesite) in the Giant Crater lava field, Medicine Lake volcano, northern California: Journal of Geophysical Research, v. 96, no. B13, p. 21,819-21,842. 
Brophy, J.G., Dorais, M.J., Donnelly-Nolan, J., and Singer, B.S., 1996, Plagioclase zonation styles in hornblende gabbro inclusions from Little Glass Mountain, Medicine Lake volcano, California-Implications for fractionation mechanisms and the formation of composition gaps: Contributions to Mineralogy and Petrology, v. 126, p. 121-136.

Castro, J.M., and Dingwell, D.B., 2009, Rapid ascent of rhyolitic magma at Chaiten volcano, Chile: Nature, v. 461, p. 780-784, doi:10.1038/nature08458.

Champion, D.E., 1980, Holocene geomagnetic secular variation in the western United States-Implications for the global geomagnetic field: U.S. Geological Survey Open-File Report 80-824, 326 p.

Champion, D.E., and Donnelly-Nolan, J.M., 1994, Duration of eruption at the Giant Crater lava field, Medicine Lake volcano, California, based on paleomagnetic secular variation: Journal of Geophysical Research, v. 99, no. B8, p. $15,595-15,604$.

Champion, D.E., and Donnelly-Nolan, J.M., 2008, Paleomagnetic sampling of Holocene silicic eruptive products at Medicine Lake volcano, southern Cascade Range: Eos, Transactions of the American Geophysical Union, v. 89, no. 53, Fall Meeting Supplement, Abstract GP51B-0766.

Champion, D.E., and Shoemaker, E.M., 1977, Paleomagnetic evidence for episodic volcanism on the Snake River Plain: Planetary Geology Field Conference on the Snake River Plain, Idaho, October 1977, NASA Technical Memorandum 78436, p. 7-8.

Chiarabba, C., Amato, A., and Evans, J.R., 1995, Variations on the NeHT high-resolution tomography method-A test of technique and results for Medicine Lake Volcano, northern California: Journal of Geophysical Research, v. 100, no. B3, p. 4035-5042.

Condie, K.C., and Hayslip, D.L., 1975, Young bimodal volcanism at Medicine Lake volcanic center, northern California: Geochimica et Cosmochimica Acta, v. 39, p. 1,165-1,178.

Donnelly-Nolan, J.M., 1988, A magmatic model of Medicine Lake volcano, California: Journal of Geophysical Research, v. 93, no. B5, p. 4412-4420.

Donnelly-Nolan, J.M., 1998, Abrupt shift in $\mathrm{d}^{18} \mathrm{O}$ values at Medicine Lake volcano (California, USA): Bulletin of Volcanology, v. 59, p. 529-536.

Donnelly-Nolan, J.M., 2008, Chemical analyses of pre-Holocene rocks from Medicine Lake Volcano and vicinity, northern California: U.S. Geological Survey Open-File Report 2008-1094, http://pubs.usgs.gov/of/2008/1094/.
Donnelly-Nolan, J.M., 2010, Geologic map of Medicine Lake volcano, northern California: U.S. Geological Survey Scientific Investigations Map 2927, scale 1:50,000, http://pubs. usgs.gov/sim/2927/.

Donnelly-Nolan, J.M., and Champion, D.E., 1987, Geologic map of Lava Beds National Monument, northern California: U.S. Geological Survey Map I-1804, scale 1:24,000.

Donnelly-Nolan, J.M., Champion, D.E., Grove, T.L., Baker, M.B., Taggart, J.E., Jr., and Bruggman, P.E., 1991, The Giant Crater lava field - Geology and geochemistry of a compositionally zoned, high-alumina basalt to Basaltic andesite eruption at Medicine Lake volcano, California: Journal of Geophysical Research, v. 96, no. B13, p. 21,84321,863 .

Donnelly-Nolan, J.M., Champion, D.E., Miller, C.D., Grove, T.L., and Trimble, D.A., 1990, Post-11,000-year volcanism at Medicine Lake volcano, Cascade Range, northern California: Journal of Geophysical Research, v. 95, no. B12, p. 19,693-19,704.

Donnelly-Nolan, J.M., Grove, T.L., Lanphere, M.A., Champion, D.E., and Ramsey, D.W., 2008, Eruptive history and tectonic setting of Medicine Lake volcano, a large reararc volcano in the southern Cascades: Journal of Volcanology and Geothermal Research, v. 177, p. 313-328, doi:10.1016/j.jvolgeores.2008.04.023.

Donnelly-Nolan, J.M., Nathenson, M., Champion, D.E., Ramsey, D.W., Lowenstern, J.B., and Ewert, J.W., 2007, Volcano hazards assessment for Medicine Lake volcano, northern California: U.S. Geological Survey Scientific Investigations Report 2007-5174A, 26 p., http://pubs.usgs. gov/sir/2007/5174/a/.

Dzurisin, D., Donnelly-Nolan, J.M., Evans, J.R., and Walter, S.R., 1991, Crustal subsidence, seismicity, and structure near Medicine Lake volcano, California: Journal of Geophysical Research, v. 96, p. 16,319-16,333.

Dzurisin, D., Poland, M.P., and Burgmann, R., 2002, Steady subsidence of Medicine Lake volcano, northern California, revealed by repeated leveling surveys: Journal of Geophysical Research, v. 107, no. B12, doi:10.1019/2001JB000893.

Eichelberger, J.C., 1975, Origin of andesite and dacite-Evidence of mixing at Glass Mountain in California and at other circum-Pacific volcanoes: Geological Society of America Bulletin, v. 86, p. 1381-1391.

Eichelberger, J.C., 1980, Vesiculation of mafic magma during replenishment of silicic magma reservoirs: Nature, v. 288, p. 446-450. 
Eichelberger, J.C., 1981, Mechanism of magma mixing at Glass Mountain, Medicine Lake Highland volcano, California, in Johnston, D.A., and Donnelly-Nolan, J., eds., Guides to some volcanic terranes in Washington, Idaho, Oregon, and northern California: U.S. Geological Survey Circular 838 , p. $183-189$.

Eichelberger, J.C., Chertkoff, D.G., Dreher, S.T., and Nye, C.J., 2000, Magmas in collision-Rethinking chemical zonation in silicic magmas: Geology, v. 28, no. 7, p. 603-606.

Evans, J.R., and Zucca, J.J., 1998, Active high-resolution seismic tomography of compressional wave velocity and attenuation structure at Medicine Lake volcano, northern California Cascade Range: Journal of Geophysical Research, v. 93, no. B12, p. 15,016-15,036.

Finch, R.H., 1933, Burnt lava flow in northern California: Zeitschrift fur Vulkanologie, v. XV, p. 180-185.

Fink, J.H., and Pollard, D.D., 1983, Structural evidence for dikes beneath silicic domes, Medicine Lake Highland volcano, California: Geology, v. 11, p. 458-461.

Finn, Carol, and Williams, D.L., 1982, Gravity evidence for a shallow intrusion under Medicine Lake volcano, California: Geology, v. 10, p. 503-507.

Fisher, R.V., 1964, Maximum size, median diameter, and sorting of tephra: Journal of Geophysical Research, v. 69, no. 2, p. 341-355.

Gerlach, D.C., and Grove, T.L., 1982, Petrology of Medicine Lake Highlands volcanics - Characterization of the end members of magma mixing: Contributions to Mineralogy and Petrology, v. 80, p. 147-159.

Grove, T.L., and Donnelly-Nolan, J.M., 1986, The evolution of young silicic lavas at Medicine Lake Volcano, California-Implications for the origin of compositional gaps in calc-alkaline series lavas: Contributions to Mineralogy and Petrology, v. 92, p. 281-302.

Grove, T.L., Donnelly-Nolan, J.M., and Housh, Todd, 1997, Magmatic processes that generated the rhyolite of Glass Mountain, Medicine Lake volcano, Northern California: Contributions to Mineralogy and Petrology, v. 127, p. 205-223.

Grove, T.L., Gerlach, D.C., and Sando, T.W., 1982, Origin of calc-alkaline series lavas at Medicine Lake volcano by fractionation, assimilation, and mixing: Contributions to Mineralogy and Petrology, v. 80, p. 160-182.

Grove, T.L., Kinzler, R.J., Baker, M.B., Donnelly-Nolan, J.M., and Lesher, C.E., 1988, Assimilation of granite by basaltic magma at Burnt Lava flow, Medicine Lake volcano, northern California-Decoupling of heat and mass transfer: Contributions to Mineralogy and Petrology, v. 99, p. 320-343.
Hagstrum, J.T., and Champion, D.E., 2002, A Holocene paleosecular variation record from ${ }^{14} \mathrm{C}$-dated volcanic rocks in western United States: Journal of Geophysical Research, v. 107, no. B1, 2025, doi:10.1029/2001JB000524.

Hart, W.K., Aronson, J.L., and Mertzman, S.A., 1984, Areal distribution and age of low-K, high-alumina olivine tholeiite magmatism in the northwestern Great Basin: Geological Society of America Bulletin, v. 95, p. 186-195.

Heiken, Grant, 1978, Plinian-type eruptions in the Medicine Lake Highland, California, and the nature of the underlying magma: Journal of Volcanology and Geothermal Research, v. 4, p. 375-402.

Kinzler, R.J., Donnelly-Nolan, J.M., and Grove, T.L., 2000, Late Holocene hydrous mafic magmatism at the Paint Pot Crater and Callahan flows, Medicine Lake Volcano, Northern California and the influence of $\mathrm{H}_{2} \mathrm{O}$ in the generation of silicic magmas: Contributions to Mineralogy and Petrology, v. 138, p. 1-16.

Kirschvink, J.L., 1980, The least-squares line and plane and the analysis of paleomagnetic data: Geophysical Journal of the Royal Astronomical Society, v. 62, p. 699-718.

Lowenstern, J.B., Donnelly-Nolan, J.M., Wooden, J.L., and Charlier, B.L.A., 2003, Volcanism, plutonism and hydrothermal alteration at Medicine Lake volcano, California: Proceedings of the Twenty-Eighth Workshop on Geothermal Reservoir Engineering, Stanford University, California, January $27-29$, p. 1-8.

Lowenstern, J.B., Persing, H.M., Wooden, J.L., Lanphere, M., Donnelly-Nolan, J., and Grove, T.L., 2000, U-Th dating of single zircons from young granitoid xenoliths - New tools for understanding volcanic processes: Earth and Planetary Science Letters, v. 183, p. 291-302.

Lutz, S.J., Hulen, J.B., and Schriener, A., Jr., 2000, Alteration, geothermometry, and granitoid intrusions in well GMF 31-17, Medicine Lake volcano geothermal system, California: Proceedings of the Twenty-Fifth Workshop on Geothermal Reservoir Engineering, Stanford University, Stanford, California, January 24-26.

McCrory, P.A., Blair, J.L., Waldhauser, F., and Oppenheimer, D.H., 2012, Juan de Fuca slab geometry and its relation to Wadati-Benioff zone seismicity: Journal of Geophysical Research, v. 117, B09306, doi:10.1029/2012JB009407, 23 p.

Mertzman, S.A., and Williams, R.J., 1981, Genesis of Recent silicic magmatism in the Medicine Lake Highland, California-Evidence from cognate inclusions found at Little Glass Mountain: Geochimica et Cosmochimica Acta, v. 45, p. 1463-1478. 
Miyashiro, A., 1974, Volcanic rock series in island arcs and active continental margins: American Journal of Science, v. 274, p. 321-355.

Muffler, L.J.P., Clynne, M.A., and Champion, D.E., 1994, Late Quaternary normal faulting of the Hat Creek Basalt: Geological Society of America Bulletin, v. 106, p. 195-200.

Nathenson, M., Donnelly-Nolan, J.M., Champion, D.E., and Lowenstern, J.B., 2007, Chronology of postglacial eruptive activity and calculation of eruption probabilities for Medicine Lake volcano, northern California: U.S. Geological Survey Scientific Investigations Report 2007-5174-B, 10 p., http://pubs.usgs.gov/sir/2007/5174/b/.

Pallister, J.S., Diefenbach, A.K., Burton, W.C., Munoz, J., Griswold, J.P., Lara, L.E., Lowenstern, J.B., and Valenzuela, C.E., 2013, The Chaiten rhyolite lava dome-Eruption sequence, lava dome volumes, rapid effusion rates and source of the rhyolite magma: Andean Geology, v. 40, no. 2, p. 277-294.

Parker, A.L., Biggs, J., Annen, C., and Lu, Z., 2013, Investigating subsidence at volcanoes in northern California using InSAR: American Geophysical Union Fall Meeting abstract V11D-02.

Peacock, M.A., 1931, The Modoc Lava Field, northern California: The Geographical Review, v. 21, p. 259-275.

Pitt, A.M., Hill, D.P., Walter, S.W., and Johnson, M.J.S., 2002, Midcrustal, long-period earthquakes beneath northern California volcanic areas: Seismological Research Letters, v. 73, no. 2, p. 144-152.
Poland, M., Burgmann, R., Dzirusin, D., Lisowski, M., Masterlark, T., Owen, S., and Fink, J., 2006, Constraints on the mechanism of long-term, steady subsidence at Medicine Lake volcano, northern California, from GPS, leveling, and InSAR: Journal of Volcanology and Geothermal Research, v. 150, p. $55-78$.

Powers, H.A., 1932, The lavas of the Modoc Lava-Bed quadrangle, California: The American Mineralogist, v. 17, no. 7, p. 253-294.

Ritter, J.R.R., and Evans, J.R., 1997, Deep structure of Medicine Lake volcano, California: Tectonophysics, v. 275, p. 221-241.

Sisson, T.W., and Layne, G.D., 1993, $\mathrm{H}_{2} \mathrm{O}$ in basalt and basaltic andesite glass inclusions from four subduction-related volcanoes: Earth and Planetary Science Letters, v. 117, p. 619-635.

Tuffen, H., James, M.R., Castro, J.M., and Schipper, C.I., 2013, Exceptional mobility of an advancing rhyolitic obsidian flow at Cordon Caulle volcano in Chile: Nature Communications, doi:10.1038/ncomms3709.

Turrin, B.D., Christiansen, R.L., Clynne, M.A., Champion, D.E., Gerstel, W.J., Muffler, L.J.P., and Trimble, D.A., 1998, Age of Lassen Peak, California, and implications for the ages of Late Pleistocene glaciations in the Southern Cascade Range: Geological Society of America Bulletin, v. 110, p. 931-945. 


\section{息}

Printed on recycled paper 